\title{
RUSSIA'S “ORTHODOX” FOREIGN POLICY: THE GROWING INFLUENCE OF THE RUSSIAN ORTHODOX CHURCH IN SHAPING RUSSIA'S POLICIES ABROAD
}

\author{
PROF. ROBERT C. BLITT* \\ TABLE OF CONTENTS
}

1. Introduction.

2. The Russian Orthodox Church's Foreign Policy

Mandate

3. Russian Foreign Policy and Disregard for the Constitutional Obligations of Secularism, Separation, and Nondiscrimination.

3.1. The Ideological Centrality of Orthodoxy in Russian Foreign Policy as Expressed through Euphemism

3.1.1. The Role of "Spirituality" in Russia's National

Security Strategy.

3.1.2. A Note on Culture as a Synonym for Orthodoxy ......374

3.1.3. "Spiritual Security" \& "Spiritual Revival".

3.2. Putting Rhetoric into Practice: The Ascendancy of "Spirituality" in Russia's Foreign Policy....

3.2.1. Russian Orthodox Church-Ministry of Foreign

Affairs Working Group

3.2.2. Russkiy Mir Foundation: A Chimera State-Church

Foreign Policy Tool.

3.2.3. Support for Days of Spiritual Culture

3.2.4. Facilitating an Exclusive Podium for Orthodoxy at the United Nations....

* Associate Professor of Law, University of Tennessee College of Law, Knoxville, TN. A draft of this paper was presented at the Central European University during a conference on "Religion in the Public Square", held June 4-5, 2010 in Budapest, Hungary. I am grateful to Andras Sajo and Renata Uitz for extending an invitation to participate in this important gathering. 
3.2.4.1. Sponsoring the Spiritual Revival of Russia

Exhibit

3.2.4.2. Supporting the Establishment of a U.N.

Consultative Council on Religions.....

3.2.4.3. Kirill at the U.N.

3.2.5. Building the ROC's Reach: Unification \& Church

Construction Abroad.

3.2.5.1. ROC/ROCOR Merger Overseen by Putin ......410

3.2.5.2. Laying Cornerstones for New Churches and

Reclaiming Church Property Outside Russia.....

3.2.5.3. ROC as Diplomatic Lever

4. The Implications of "Orthodox" Russian Foreign Policy Abroad and at Home.

4.1. Challenging Established Human Rights Norms within the International System 4.2. Using International Developments to Reinforce Adverse Human Rights Situation at Home

5. Conclusion

\section{INTRODUCTION}

The government of Russia and the Russian Orthodox Church $(\mathrm{ROC})^{1}$-the country's predominant religious group-recently underwent back-to-back changes in each institution's respective leadership. This coincidence of timing has afforded a unique opportunity to reexamine the status of constitutional secularism and church-state relations in the Russian Federation. In a previous article, I explored the domestic implications of President Dmitri Medvedev and Patriarch Kirill's relationship and concluded that in the short space of two years, their partnership served to further entrench a discriminatory three-tiered status system for religious groups and-perhaps more significantly-has generated multiple new channels of influence for the ROC in Russian social and political life, including handing the Church its long-coveted prizes of access to the public education system and the military. ${ }^{2}$ To be

1 The terms Russian Orthodox Church, ROC, Russian Church, the Church, and Orthodox Church are used interchangeably herein to refer to the Moscow Patriarchate.

2 See, e.g., Robert C. Blitt, One New President, One New Patriarch, and a Generous Disregard for the Constitution: A Recipe for the Continuing Decline of Secular Russia, 43 
certain, these developments represent a significant blow to constitutional secularism in Russia, but do not tell the entire story.

As this Article will demonstrate, the ROC's influence is increasingly evident beyond the realm of domestic policies. The Patriarch today enjoys the ear of Russia's Foreign Ministry and plays a key role in both formulating and advancing Russian interests abroad. Consequently, the breakdown in the constitutional principle of secularism so evident in domestic affairs has spilled over into Russia's foreign policy, leading to the bizarre reality whereby a secular state is advocating on behalf of religious Orthodoxy and "traditional" values abroad. By assessing the various points of cooperative overlap and commonality shared by the ROC and Russian government on this plane, the following Article posits that the practice of mutual reinforcement in foreign policy objectives as between the ROC and government of Russia not only undermines respect for the Russian constitution, but actually risks exacerbating already adverse domestic conditions related to freedom of expression and freedom of religion or belief, as well as widening the rift between constitutional text and actual practice.

\section{THE RUSSIAN ORTHODOX CHURCH'S FOREIGN POLICY MANDATE}

The Moscow Patriarchate, like the Russian government, is actively concerned about developments outside of Russia and the potential implications these developments may have on the home front. This concern is not limited to the "near abroad" former Soviet bloc states or the canonical territory of the Moscow Patriarchate, as defined to include "Russia, Ukraine, Byelorussia, Moldavia, Azerbaijan, Kazakhstan, Kirghizia, Latvia, Lithuania,

\footnotetext{
VAND. J. TRANSNAT'L L. 1337, 1339 (2010) [hereinafter Blitt, One New President] (arguing that the government and the ROC have continued to "willfully undermine the constitutional principles of secularism, nondiscrimination, and equality through a variety of special privileges, cooperation agreements, and legislative initiatives"); see also Robert C. Blitt, How to Entrench a De Facto State Church in Russia: A Guide in Progress, 2008 BYU L. REV. 707, 708-78 (2008) [hereinafter Blitt, How to Entrench a De Facto State Church in Russia] (examining "the chain of events that has left the ROC poised to continue to expand its influence over government policy under the Putin-orchestrated administration of President Medvedev").
} 
Tajikistan, Turkmenia, Uzbekistan and Estonia."3 Rather, it extends to all other states where Russian Orthodox Christians may be living, provided they "voluntarily" join the Patriarchate's jurisdiction. ${ }^{4}$ Even more broadly, the Church's purview is truly global, covering virtually every country as well as many major intergovernmental institutions. In Patriarch Kirill's mind,

[t]he universal nature of the Christian teaching makes us interested in various spheres of the life of society. The Church acts on equal footing as a subject of relations with different states and with international public and political organizations. We defend our values and promote the rights and interests of our congregations. ${ }^{5}$

Most of the ROC's effort abroad is managed through its department of external church relations (DECR), which is tasked with the sweeping responsibility of "maintain[ing] the Church's relations with Local Orthodox Churches, non-Orthodox Churches, Christian organizations and non-Christian religious communities, as well as governmental, parliamentary, inter-governmental, religious and public bodies abroad and public international organizations." 6 In practice, the DECR operates as a foreign ministry that hosts ambassadors, travels widely, and interacts with the United Nations (U.N.), European Union (EU), and Organization for Security and Cooperation in Europe (OSCE), among other international organizations. ${ }^{7}$

The Church's foreign policy objectives are multi-pronged and diverse, yet they share many similarities with the government of Russia's foreign policy priorities. As Patriarch Kirill remarked in a

3 The Statute of the Russian Orthodox Church, DEP'T FOR EXTERNAL CHURCH REL. OF THE MOsCOW PATRIARCHATE, pt. I, $\S 3$ http://orthodoxeurope.org/page /3/15.aspx (last visited Nov. 19, 2011).

4 Id.

5 Church Diplomacy Is Not Just a Matter of Inter-Church Relations, DiPlomat, Sept. 2008, at 12-13.

6 Department for External Church Relations of the Moscow Patriarchate (DECR), DEP'T FOR EXTERNAL CHURCH REL. OF THE RUSSIAN ORTHODOX CHURCH, http://www.mospat.ru/en/department/today/ (last visited Nov. 19, 2011).

7 See, e.g., The DECR Secretariat for the Far Abroad, DEP'T FOR EXTERNAL CHURCH REL. OF THE RUSSIAN ORTHODOX CHURCH, http:/ / www.mospat.ru/en/department / secretary-2/ (last visited Nov. 19, 2011) (discussing the role and tasks of the DECR "secretariat for the far abroad"). 
letter to Foreign Minister Sergei Lavrov on the occasion of his $60^{\text {th }}$ birthday, "[d]uring your service as foreign minister, the cooperation between the Russian foreign policy department and the Moscow Patriarchate has considerably broadened." 8 The following section will discuss several examples illustrating this intimate cooperation and demonstrate how the lockstep efforts by the Russian government and ROC to advance them compromises Russia's secular constitution and respect for human rights, both abroad as well as at home.

\section{RUSSIAN FOREIGN POLICY AND DISREGARD FOR THE} CONSTITUTIONAL OBLIGATIONS OF SECULARISM, SEPARATION, AND NONDISCRIMINATION

Moscow has lost sight of its constitutional obligations related to secularism and separation of church and state even in the formulation and execution of its foreign policy. In the first instance, a break is evident in the rhetoric disseminated through Russia's Ministry of Foreign Affairs (MOFA) as well as in speeches by President Medvedev and others. The central concept being espoused here is neatly encapsulated in the constant refrain in favor of "spiritual values." So pervasive is this notion that it has implanted itself at the apex of Russia's strategic planning, in both the National Security Strategy, as well as the Foreign Policy Concept. On the second level, beyond words and ideological positioning, numerous concrete policy ventures implemented abroad illustrate a governmental willingness to further burnish the already glossy but nevertheless constitutionally verboten-patina of religious favoritism routinely demonstrated in the context of domestic affairs.

8 Patriarch Kirill's Congratulatory Message to Russian Foreign Minister S. Lavrov, DeP'T FOR EXTERnAl CHURCH Rel. OF THE Russian ORTHODOX CHURCH (Mar. 22, 2010), http://www.mospat.ru/en/2010/03/22/news14871/. 


\subsection{The Ideological Centrality of Orthodoxy in Russian Foreign Policy as Expressed Through Euphemism}

\subsubsection{The Role of "Spirituality" in Russia's National Security Strategy}

Russia's National Security Concept (NSC) from 2000 garnered attention for its unusual emphasis on the need for "spiritual renewal."9 According to this document, Russia faced a dual threat: internally by "the depreciation of spiritual values" which "promote[s] tension in relations between regions and the center"10 and externally by "cultural-religious expansion into the territory of Russia by other states." 11 To eliminate these risks to national security, the NSC called for inter alia, "protection of the cultural, spiritual, and moral legacy ... the formation of government policy in the field of the spiritual and moral education of the population, and ... counteraction against the negative influence of foreign religious organizations and missionaries." 12

Although the NSC invoked the generic term "spirituality," in substance the policy objective intended the restoration of Orthodoxy specifically, and to a much lesser degree Russia's other "traditional faiths." 13 Indeed, the NSC went on to brand foreign religious organizations a "negative influence," despite the fact that many of these religions had existed in Russia for decades. While the tactics of some missionary groups operating in Russia following the collapse of the Communism rightfully may be deserving of criticism, the fact that all foreign religious

9 National Security Concept of the Russian Federation, MinISTRY OF FOREIGN AFF. OF THE RUSSIAN FED'N, pt. II (Jan. 10, 2000), http://www.mid.ru/bdomp/nsosndoc.nsf/1e5f0de28fe77fdcc32575d900298676/36aba64ac09f737fc32575d9002bbf 31 ! OpenDocument.

10 Id. at pt. III.

11 Id. at pt. IV.

12 Id.

13 Julie Elkner, Constructing the Chekist: The Cult of State Security in Soviet and Post-Soviet Russia 250-51 (2009) (unpublished Ph.D. dissertation, Kings College, University of Cambridge) (on file with author) (footnote omitted) (explaining that the original use of the term "spiritual values," dating back to 1992, was meant "to flag a shift away from Soviet militant atheism and from state persecution of religious believers. Subsequently, however, this linkage ... has been taken up and used as a weapon for ends which are far removed from the principles guiding the legislators who drafted this law."). 
organizations were branded a threat stemmed from the indiscriminate attacks arising from various domestic sources, including some Russian academics who argued that most missionaries "served the interests of the countries from which they came."14 The ROC heartily endorsed this vociferous criticism, painting missionary groups as a threat to "the integrity of [Russia's] national consciousness and our cultural identity," bent on destroying Russia's "traditional organization of life" and "the spiritual and moral ideal that is common to all of us." 15

More recently, in 2008 the Medvedev government released a revised National Security Strategy (NSS) intended to replace former President Vladimir Putin's NSC from 2000.16 Although at least one observer has argued that the decision to explicitly nullify certain strategies of the previous regime signaled the "opening of a new stage, perhaps in an attempt to avoid . . . being perceived as merely

14 John Anderson, Putin and the Russian Orthodox Church: Asymmetric Symphonia?, 61 J. INT'L AFF. 185, 194 (2007).

15 Marat S. Shterin \& James T. Richardson, Local Laws Restricting Religion in Russia: Precursors of Russia's New National Law, 40 J. Church \& St. 319, 333 n.48 (1998) (quoting Article 9 of the Council [Sobor] of the Archbishops of the Russian Orthodox Church, December, 1994, unpublished). As an example of how this policy has played out against Russia's Protestant community, see Clifford J. Levy, At Expense of All Others, Putin Picks a Church, N.Y. TIMES, Apr. 24, 2008, http://www.nytimes.com/2008/04/24/world/europe/24church.html?pagewant ed=all (describing how the Kremlin's surrogates have made the ROC the "de facto official religion," while suppressing religious freedom amongst the Protestant community) and see related video, A Crackdown on Russian Protestants, N.Y. TIMES, Apr. 23, 2008 http:/ / video.nytimes.com/video/2008/04/23/world/1194817098599/acrackdown-on-russian-protestants.html (narrating the Russian government's suppression of Protestant churches).

16 Presidential Decree, President Dmitry Medvedev, Security Council of the Russian Federation, Strategiia natsional'noi bezopasnosti Rossiiskoi Federatsii do 2020 goda [National Security Strategy of the Russian Federation until 2020], Decree No. 537 (May 12, 2009), available at http://www.scrf.gov.ru /documents/1/99.html (setting the strategy of the Russian Federation's national security strategy until 2020, the condition and trends of development of the modern world and Russia's relations, and addressing Russian national interests and priorities). The Decree also declared null and void the Presidential Decree of Dec. 17, 1997, Decree No. 1300 "On approval of the National Security Concept of the Russian Federation" (Collected Legislation of the Russian Federation, 1997, No. 52, Art. 5909) and the Presidential Decree of Jan. 10, 2000, Decree No. 24 "On the Concept of National Security of the Russian Federation" (Collected Legislation of the Russian Federation, 2000, No. 2, Art. 170). Id. 
a continuation of Putin's policies,"17 many aspects of Medvedev's 2008 NSS in fact embody a clear continuation of Putin's strategic vision. ${ }^{18}$ For example, "intelligence and other activities of special services and organizations, foreign governments and individuals"19 are listed as the primary threat to Russia's national security, beating out even the activities of terrorist organizations. ${ }^{20}$ The need to combat this bogeyman-ostensibly manifested under the guise of foreign religious organizations and nongovernmental organizations (NGOs)-through the creation of various bureaucratic hurdles and other tactics is torn directly from Putin's playbook and enthusiastically supported by the ROC. ${ }^{21}$

To make more explicit this continuation in policy, Medvedev specifically singles out the perceived threat posed by religious and other organizations intending to disrupt Russian unity and territorial integrity, and destabilize the political and social status quo. ${ }^{22}$ These groups have at various times been labeled as

17 Javier Morales, Russia's New National Security Strategy: Towards a 'Medvedev Doctrine'?, REAL INSTITUTO ElCANO (Sep. 25, 2009), http://www.realinstitutoelcano.org/wps/portal/rielcano_eng/Content?WCM_ GLOBAL_CONTEXT=/elcano/elcano_in/zonas_in/ari135-2009.

18 Medvedev's "decision" to forgo a reelection campaign in 2012-thus clearing the way for Putin's uncontested return to the presidency - underscores the ephemeral and dependent nature of his brief tenure, and validates the consistency in policies as between the 2000 NSC and 2008 NSS.

19 National Security Strategy of the Russian Federation until 2020, supra note 16 , at pt. $\operatorname{IV}(2)(37)$.

$20 I d$. (listing the source of danger for the state and national security).

21 See, e.g., Matthew Schofield, Putin Cracks Down on Nongovernmental Organizations, MCCLATCHY (Feb. 20, 2007), http://www.mcclatchydc.com /190/story/15642.html (quoting Putin as stating, "I think that it is clear for all . . . when these nongovernmental organizations are financed by foreign governments, we see them as an instrument that foreign states use to carry out their Russian policies"). The ROC strongly believes that international human rights norms promote a "western" anti-religious agenda that poses an immediate threat to Russian traditional (Orthodox) values. See also Robert C. Blitt, "Babushka Said Two Things - It Will Either Rain or Snow; It Either Will or Will Not": An Analysis of the Provisions and Human Rights Implications of Russia's New Law on Non-governmental Organizations as Told Through Eleven Russian Proverbs, 40 GEO. WASH. INT'L L. REV. 1, 4 (2008) (discussing amendments to the Russian NGO laws, which were signed by Putin in 2006, and imposed "tighter restrictions" on NGOs, especially those focusing on human rights).

22 National Security Strategy of the Russian Federation until 2020, supra note 16 , at pt. $\operatorname{IV}(2)(37)$ (setting the main sources of danger for the state and national security). 
"weapons [of] destruction" designed to promote American geopolitical interests, ${ }^{23}$ and more recently, by a Russian court in the case of Scientology, as extremist and "undermining the traditional spiritual values of the citizens of the Russian Federation." 24 This latter feat is impressive particularly in the face of the European Court of Human Rights' (ECtHR) ruling rejecting Russia's decision to deny the same Scientology branches (in Surgut and Nizhnekamsk) status as a religious group because they had not existed for at least 15 years in Russia. ${ }^{25}$ Scientology now joins the Jehovah Witnesses and the collected works of Said Nursi ${ }^{26}$ on Russia's ever-growing list of banned extremist materials. ${ }^{27}$

\footnotetext{
23 Anderson, supra note 14, at 194.

24 Russia Bans Scientology Literature, UnITED PRESS INTERNATIONAL (Apr. 22, 2010), http://www.upi.com/Top_News/US/2010/04/22/Russia-bansScientology-literature/UPI-47381271975222/ (quoting MosCOW TIMES).

25 Church of Scientology Moscow v. Russia, App. No. 18147/02, 208 Eur. Ct. H.R. (2007), http://cmiskp.echr.coe.int/tkp197/view.asp?item=1\&portal=hbkm \&action=html\&highlight=18147/02\&sessionid=82092679\&skin=hudoc-en (holding that the Russian government had violated the rights of the Church of Scientology in denying its registration as a religious organization). The ECtHR additionally found the government "did not in good faith and had neglected their duty to be neutral and impartial vis-à-vis the Church's religious community." Id. The decision to list Scientology as an extremist group will, to say the least, complicate that organization's effort to secure implementation of the ECtHR's decision.

26 Geraldine Fagan, Russia: Said Nursi Ban Brands Moderate Muslims As Extremist, FORUM 18 (June 27, 2007), http://wwrn.org/articles/25508 /?\&place $=$ russia\&section $=$ church-state (quoting Russia's Ombudsman for Human Rights, Vladimir Lukin, who defended Nursi's writings in an open letter to the district court hearing the case).
}

No form of opposition to citizens due to their choice of world view (religious or non-religious) is contained in the books and brochures, still less calls for religious hatred and intolerance .... . It is very important that we do not allow interference in the convictions and beliefs of millions of citizens on the poorly grounded, unproven pretext of fighting against extremism, as this really could provoke wide-scale violations of their right to freedom of belief

Id.; see also U.S. COMM'N ON INT'L RELIGIOUS FREEDOM, ANNUAL REPORT 2010, 174 (2010), available at http://www.uscirf.gov/images/annual\%20report\%202010.pdf (stating followers of Kurdish theologian, Said Nursi, "are not known to have advocated or engaged in violence").

27 Federation Ministry of Justice, Federal'nyi spisok ekstremistskikh materialov [The Federal List of Extremist Materials], Federal Law on the Counteraction of Extremist Activity 2002, No. 114-FZ, http://www.minjust.ru /ru/activity/nko/fedspisok/ (stating that production, possession, or distribution 
Even Medvedev's stated belief that the "main idea" behind his NSS is "security through development" 28 appears derivative of Putin's previous approach. ${ }^{29}$ Here too, the recycled emphasis on development for Russia's citizens creates prominent space for the role of spirituality and the ROC. ${ }^{30}$ In 2009, the ROC and United Russia expressed their intent to "jointly decide . . . what their common values are and what modernization tasks must be accomplished" in the context of Russia's development plans. ${ }^{31}$ The party of Putin and Medvedev went on to assert that "Russian modernization should be based on Orthodox faith." 32 Conveniently, Medvedev's NSS laid the groundwork for this step by calling for greater cooperation with institutions of civil society, including religious groups. Under the rubric of countering threats to national security that may impede the development of Russian

of materials included in the list are punishable under Art. 13 and listing the names of extremist's materials). Between March 2010 and November 2011, the list has grown from 614 to 979 prohibited items. Id.

28 See Dmitry Medvedev, President of Russia, Beginning of Meeting with Security Council On National Security Strategy of the Russian Federation Through to 2020 and Measures Necessary to Implement It (Mar. 24, 2009), available at http://archive.kremlin.ru/eng/speeches/2009/03/24/2056_type82913_214288 .shtml (identifying achievement of strategic goals set for the country as the main objective behind Medvedev's national security strategy).

29 Putin's 2000 security strategy mentioned development no fewer than twenty times. See National Security Concept of the Russian Federation, supra note 9 (highlighting the role of development as means of establishing national security).

30 Remarkably, two separate analyses of the 2009 NSS fail to mention even in passing the central role envisioned for spirituality and culture in guaranteeing Russia's national security. See Marcel de Haas, Medvedev's Security Policy: A Provisional Assessment, 62 Russian AnAlyTiCAL Dig. 2, 3 (2009), available at http:/ / www.res.ethz.ch/analysis/rad/details.cfm?lng=en\&id=101960

("According to the NSS, Russia's ability to defend its national security depended above all on the country's economic potential."); see also Henning Schröder, Russia's National Security Strategy to 2020, 62 Russian ANALyTiCAl Dig. 6, 7 (2009), available at http://www.res.ethz.ch/analysis/rad/details.cfm?lng=en\&id=101960 (emphasizing the importance of economic development for Russian national security).

31 Church, United Russia Want State-Church Partnership Sealed by Laws, INTERFAX, Dec. 1, 2009, available at Factiva, Doc. No. DANWS00020091202e5c1000ry (explaining that the "Moscow Patriarchate wants the government to set targets for Russia's development" together with the Church).

32 United Russia Considers Orthodoxy as Moral Basis for Modernization, INTERFAX (Feb. 17, 2010), http:/ / www.interfax-religion.com/?act=news\&div=6946. 
citizens, the NSS endorsed such cooperation as a means of "ensur[ing] the preservation of cultural and spiritual heritage" and addressing problems related to the "spiritual life of society." 33

Medvedev's fallback on spirituality as the adhesive for a coherent national security policy generates significant opportunities for the Church to play an instrumental role in shaping Russia's national development priorities, and as a natural extension of this, impacting Russia's security policy and threat perception as well. Notably, all senior governmental officials in Russia are speaking from the same set of spirituality-infused talking points. At an exhibit on Orthodox Russia, Medvedev remarked that the "[i]ntransient spiritual values of Orthodoxy and other traditional confessions have always been at the centre of our national identity: Today [sic] they continue to facilitate moral and ethnical renovation of Russian society and promote tolerance, patriotism and civic consciousness among young people." 34 During an Orthodox Christmas Eve meeting with Patriarch Kirill at the ROC's Danilov Monastery, Prime Minister Putin praised the Church for "educating citizens in a spirit of patriotic love for their country and passing on a love for spiritual values and history." 35 Speaking to the OSCE, Russia's Deputy Minister of Foreign Affairs invoked spiritual values as a component of Russia's security interests. ${ }^{36}$ And finally, Foreign Minister Larvov has explained the Russian government's interest in Orthodox religious sites outside

33 National Security Strategy of the Russian Federation until 2020, supra note 16 , at pt. $\operatorname{IV}(3)(52)$.

34 Medvedev's Wife Visits Exhibition "Orthodox Russia" in Moscow, ItAR-TASs, Nov. 4, 2009.

35 Alexandra Odynovaand Galina Stolyarova, Church Calls For Return of Treasures, THE ST. PETERSBURG TIMES, May 11, 2010, http://www.sptimes.ru/story/31417.

36 See Statement by Deputy Minister of Foreign Affairs Alexander Grushko at the Opening of the OSCE Annual Security Review Conference (July 1, 2008), available

http://www.ln.mid.ru/Brp_4.nsf/arh/5A744793B7994EF9C325747A004FBD70?O penDocument ("Of course, these processes cannot but affect the security interests of Russia, which in all parameters - cultural, social and those relating to spiritual values - is an integral part of Europe."). 
of Russia as a natural extension of the "spiritual revival . . taking place in Russia, [and] our return to spiritual values and shrines." 37

\subsubsection{A Note on Culture as a Synonym for Orthodoxy}

It is worth underscoring that the ostensibly dogma-neutral concept of "spiritual . . . development" 38 that entered Russia's lexicon with Putin's 2000 NSC entails a very particular interpretation limited in the main to Russian Orthodoxy. This is evidenced in the active promotion of government-funded programs such as Days of Russian Spiritual Culture, ${ }^{39}$ as well as in Russia's 2008 Foreign Policy Concept (FPC), ${ }^{40}$ which among other things acknowledges that the Russian government "actively interacts with the Russian Orthodox Church and other main confessions of the country" for the purpose of strengthening Russia's international security. ${ }^{41}$

The discussion of how "spirituality" has infiltrated Russia's national security strategy rhetoric would be incomplete without also examining the connection between spirituality and culture in Russia's NSS and FPC. From the content of these documents, it is clear that culture is considered inclusive of religion, and more specifically, of Russian Orthodoxy. This linkage in turn generates additional points of entry for the ROC, from which it is able to further challenge the secular promise of Russia's constitution. According to the NSS, the "threats to national security within the cultural arena are the perceived domination of mass (i.e., Western) culture targeting the spiritual needs of marginalized groups and the unlawful encroachment on cultural objects." 42 To meet these

37 Interview by Cyprus News Agency with Sergei Lavrov, Russian Foreign Minister (Dec. 26, 2007), available at http://www.ln.mid.ru/Brp_4.nsf/arh /86B186B9810C0834C32573BD0046C453?OpenDocument.

38 National Security Concept of the Russian Federation, supra note 9, at pt. II.

39 See infra note 107 and accompanying text (providing further discussion on this program).

40 See The Foreign Policy Concept of the Russian Federation, Ministry OF ForeIGN AFF. OF THE RUSSIAN FED'N, pt. 2 (July 12, 2008), http://www.mid.ru/nsosndoc.nsf/0e9272befa34209743256c630042d1aa/cef95560654d4ca5c32574960036c ddb?opendocument (detailing Russia's foreign policy objectives, as approved by Medvedev).

$41 \quad$ Id. at pt. 3.

42 National Security Strategy of the Russian Federation until 2020, supra note 16 , at pt. $\operatorname{IV}(7)(80)$. 
challenges, the NSS endorses "the paramount role of culture in reviving and preserving moral values and strengthening the spiritual unity of the multinational people of the Russian Federation." 43 The FPC paints a similar picture, concluding that the increase in cultural and civilizational diversity necessitates creating a larger role for religion in shaping international relations. To facilitate this role, the document calls for engaging the "common denominator that has always existed in major world religions." 44

With this outlook in place, government officials make the ROC's tie-in with Russian culture explicit. According to Foreign Minister Lavrov, Russia's MOFA:

maintains the closest ties with the Russian Orthodox Church, which is the church most Russians belong to. Our cooperation is one of the long-time traditions of domestic diplomacy. We value the influence Orthodoxy had on the formation of our statehood, the shaping of culture and molding of the consciousness of Russia's multi-ethnic people. We also commend the role played by the Russian Orthodox Church in the life of present-day Russia as one of the consolidating forces of Russian society. 45

Minister of Culture Alexander Avdeev makes the equation of Russian culture with Russian Orthodoxy even more explicit: "Russian culture will flourish and remain the center of the national idea only if it will be in very close dialogue with the Russian Orthodox Church, if it is connected with the understanding that the spiritual and historical value are both sacred values." 46

43 Id. at pt. $\operatorname{IV}(7)(84)$. The task of strengthening the spiritual unity of a multinational-and multireligious - people may strike some as being contradictory. It is also questionable whether the promotion of such a task is rightfully suited to a secular government.

44 The Foreign Policy Concept of the Russian Federation, supra note 40, at pt. 2. Here again, use of the term "major world religions" implies an exclusive and discriminatory approach to which groups might reasonably be included as part of such engagement.

45 Diplomacy Needs a Moral Foundation, Diplomat, Sept. 2008, at 3-4 (quoting an interview with Sergei Lavrov).

46 Aleksandr Avdeev: Rossiiskaia kultura budet uspeshno razvivat'sia tol'ko v sotrudnichestve s Russkoi pravoslavnoi tserkov'iu [Alexander Avdeev: Russian culture will flourish only in cooperation with the Russian Orthodox Church], RUSSKIY MIR 
Confirming the Moscow Patriarchate's intent to take advantage of these entry points, its Basis of the Social Concept already endorses cooperation with the state in "spiritual, cultural, moral and patriotic education," as well as "culture and [the] arts" more generally. ${ }^{47}$ For the Church, culture at its essence is religion: "[ $\left.t\right]$ he Latin word cultura meaning cultivation, breeding, education, development is derived from cultus meaning veneration, worship, cult. This points to the religious roots of culture." 48 Against this backdrop, Metropolitan Hilarion has called for the "complete destruction of the wall between the Church and culture that was established in Soviet times," and asserted that "[i]f the Church does not take part in the country's cultural life, culture is running the risk of turning into an anti-culture." 49 In a similar vein, Patriarch Kirill's vision of the ROC's parishes abroad embody the link between Orthodoxy and Russian culture insofar as they:

fulfill a cultural mission. They are an important link between their Motherland and the people living far away from their native country. The parishes run both Sunday

FOUND. (July 6, 2009), http://www.russkiymir.ru/russkiymir/ru/news/common /news2700.html.

47 The Basis of the Social Concept, DEP'T FOR EXTERnAl CHURCH REL. OF THE RUSSIAN ORTHODOX CHURCH, pt. III (8), http://www.mospat.ru/en/documents /social-concepts/ (last visited Nov. 19, 2011).

$48 \mathrm{Id}$. at pt. XIV(2), http://www.mospat.ru/en/documents/socialconcepts/xiv/ (last visited Nov. 19, 2011).

49 Senior Cleric Urges Russian Church to Play Greater Cultural Role, RIA Novosti, (Sept. 3, 2010), http://en.beta.rian.ru/Religion/20100309 /158137037.html. According to the ROC's Basis of the Social Concept, "if culture puts itself in opposition to God, becoming anti-religious and anti-humane and turning into anti-culture, the Church opposes it." See The Basis of the Social Concept, supra note 47, at pt. XIV(2). In the context of preservation of culture, there is a lively debate in Russia over the decision to return to the ROC icons and other religious relics held in Russian museums. As one article put it, "Prime Minister Vladimir Putin is atoning for the sins of the Bolsheviks - or delivering a heavy blow to Russian culture, depending on whom you ask." Stolyarova, supra note 35. Opposition to the return reflects concern over the Church's ability to adequately preserve the articles and questions regarding public access. The debate has also manifested itself in the decision to return real estate to the ROC, including churches that had been converted to other purposes during the Communist era. See Alexandra Odynova, Church Set to Regain Museum Treasures, THE Moscow TIMES, Apr. 28, 2010, http://www.themoscowtimes.com/news/article/churchset-to-regain-museum-treasures/404936.html (discussing a proposed bill that would return religious items from museums to the church). 
schools and grade schools for children whose parents want them to be educated in the spiritual and cultural traditions of their native country. ${ }^{50}$

Although the Russian government has placed an obvious and longstanding emphasis on restoring and protecting "spiritual" values and culture, and the ROC has heartily endorsed this policy, recent polling data suggest that Russian citizens view the country's national security priorities in a dramatically different light. According to the survey findings, the dearth of spirituality ranks at the bottom of the list of national threats facing Russia: only three percent of Russians shared the view that the "lack of spiritual values" and the "lack of culture" posed a major threat to Russia. ${ }^{51}$

\subsection{3. "Spiritual Security" \& "Spiritual Revival"}

Feeding into the government's emphasis on spiritual values, spiritual revival, and spiritual development-or perhaps even as shorthand for all these terms - is the Russian notion of "spiritual security." 52 This concept embodies efforts to protect Orthodoxy inside Russia by framing the threat of religious competition from missionaries and "nontraditional" faiths as endangering nothing less than the security of Russia. ${ }^{53}$ In part, this protection is

50 Church Diplomacy Is Not Just a Matter of Inter-Church Relations, supra note 5, at 14 .

51 Meanwhile, $11 \%$ of respondents considered the economic crisis and weak industry as a major threat facing Russia. The second threat most cited by those polled (9\%) included alcoholism, drug addiction, and Russia's shrinking population $(9 \%)$, followed closely by the perceived military threat from NATO and the West and the possibility of a third world war $(7 \%)$. Six percent considered "terrorism, poverty, low living standards, corruption, theft, bureaucracy, and unemployment" as major threats. See Opinion poll: Only 3\% of Russians think the lack of spiritual values to be a major national threat, INTERFAX (July 13, 2009), http://www.interfax-religion.com/?act=news\&div=6215 (citing a lack of spiritual values as one of the last national threats Russians are worried about).

52 See Anderson, supra note 14, at 194 (describing the inclusion of religious restoration among the Russian government's stated national security priorities).

53 According to Lawrence Uzzell, the driving force behind the linkage of spiritual security with national security can be traced back to Nikolai Trofimchuk, the head of the Religious Studies Faculty at the Russian Academy of State Service and author of EXPANSIYA, a book which makes the case that missionaries invariably serve the political interests of their home countries. Putin appointed Trofimchuk to the Kremlin's Council for Co-operation with Religious 
achieved through an alliance between the ROC and the Federal Security Service of the Russian Federation (FSB), 54 as well as the burgeoning relationship with Russia's predominant political party, United Russia.

Spiritual security also has an external connotation that relates to the role of the ROC abroad. As prime minister Putin stated in 2009, "[i]n the dialogue with other Sister-Churches, the Russian Orthodox Church has always defended and hopefully will continue to defend the national and spiritual identity of Russians." 55 This collaboration is likewise achieved by way of partnership abroad with Russia's MOFA, promoting "Russianness" and "collaborat[ing] to protect the spiritual security of the Russian diaspora from non-Orthodox religions and especially from the spread of secularism."56 Medvedev has allowed his administration to grow this exclusive partnership. At the 3rd World Congress of Compatriots Living Abroad, Medvedev addressed the task of supporting Russians abroad: "I cannot help mentioning the role of the Russian Orthodox Church and our other traditional confessions in reviving the spiritual unity of compatriots and strengthening their humanitarian and cultural ties with the historical homeland. We will certainly continue contacts between the state and appropriate confessions." 57

Organizations in 2001, but he died shortly thereafter. See Lawrence Uzzell, The Threat to Religion, ST. PETERSBURG TIMES, Sept. 7, 2001, http://www.sptimes.ru/index.php?action_id=2\&story_id=5286. See also DENNIS J. Dunn, The Catholic Church and Russia: Popes, Patriarchs, Tsars And COMMISSARS 198 (2004) (discussing Trofimchuk's opinion that "'spiritual security' is part of national security").

54 See Elkner, supra note 13, at 246 (explaining the extent of the connection between the ROC and FSB).

55 Daniel P. Payne, Spiritual Security, the Russian Orthodox Church, and the Russian Foreign Ministry: Collaboration or Cooptation?, 52 J. CHURCH \& ST. 712, 715 (2010) (footnote omitted).

56 Id. at 719.

57 Patriarch Kirill Attends the Opening of the 3d Congress of Compatriots Living Abroad, DeP'T Of EXTERnAl CHuRCH Rel. OF THE Russian ORTHODOX CHURCH (Dec. 1, 2009), http://www.mospat.ru/en/2009/12/01/news9542/. Medvedev's inclusion of "traditional confessions" rings hollow here. As part of the Congress, a meeting was held at the Danilovskaya hotel (within the Danilov Monastery compound, which serves as the patriarch's official residence) entitled "The Russian Orthodox Church and other traditional confessions in consolidating the united spiritual space of the Russian World." The substance of this meeting was directed exclusively at increasing cooperation between the MOFA and the ROC 
The outcome of this ongoing arrangement has the following symbiotic results: abroad, the government benefits from the ROC's efforts as a willing partner in reinforcing Russia's "spiritual security," which in turn boosts the channels available to it for the projection of Russian power abroad.58 On the home front, the government ensures that religious groups, or "sects," deemed by the ROC to constitute a threat are sufficiently repressed. As Daniel Payne has rightly concluded, spiritual security serves "as the basis for protecting and uniting the Russian Orthodox people against threats to its spiritual and cultural well-being, especially by limiting the amount of freedom experienced in [Russia's] civil society itself." 59 But the potential damage caused by the Russian government's preoccupation with spiritual security runs deeper still. According to Julie Elkner, insofar as Russia's FSB has "cloak[ed] itself in spiritual rhetoric, [it] will not only attain moral respectability, but will effectively place itself beyond the reach of any legitimate criticism, scrutiny or control." 60

From this more contextualized vantage point - and even before considering the practical ramifications-it would appear that the generic notions of safeguarding and promoting spiritual development, culture, and spiritual security, already establish a conceptual approach to foreign policy and national security that undercuts Russia's constitutionally mandated secularism and separation of religion and state. As the next section will demonstrate, the government and the ROC have worked diligently

abroad. See 3d World Congress of Compatriots Section Meeting on 'The Role of the ROC and Other Traditional Confessions in Consolidation of United Space of the Russian World', DEPT. FOR EXTERNAL CHURCH REL. OF THE RUSSIAN ORTHODOX CHURCH (Feb. 12, 2009), http://www.mospat.ru/en/2009/12/02/news9603/ (relating that at a meeting of the $3 \mathrm{~d}$ World Congress of Compatriots, several religious and political leaders stressed the importance of helping Russians living abroad maintain a connection to their country); see also Sviateishyi Patriarkh Aleksii prinial uchastie v zasedanii rabochei gruppy po vzaimodeistviiy MID Rossii I Russkoi Pravoslavnoi Tserkvi [Patriarch Alexy Attends a Meeting of the Working Group on the Interaction of the Russian Foreign Ministry and the Russian Orthodox Church], PRAVOSLAVIE (Nov. 21, 2007), http://www.pravoslavie.ru/news/24939.htm (quoting Russian Foreign Minister, Sergei Lavrov as stating that a working group on cooperation between the MOFA and the ROC was formed in 2003).

58 See infra 3.2.1. for additional discussion on the collaboration between the ROC and the MOFA.

59 Payne, supra note 55, at 716.

60 Elkner, supra note 13, at 291. 
to put this theoretical framework into concrete practice through a variety of tacit and intentional endeavors and partnerships. It is these tangible efforts that more definitively confirm Medvedev's willingness to allow the Moscow Patriarchate's growing role to expand beyond internal affairs and into the foreign policy realm, as well as the enthusiasm of both parties to intensify this relationship despite overriding constitutional directives of secularism, separation of religion and state, and nondiscrimination to the contrary.

\subsection{Putting Rhetoric into Practice: The Ascendancy of "Spirituality" in Russia's Foreign Policy}

The framework outlined above is not intended for the narrow purpose of rhetorical flourish alone. In fact, the ideological principles first espoused by Putin, and since expanded by Medvedev, have resulted in tangible and growing neglect by Russia's foreign policy for the constitutional principles of secularism, separation, nondiscrimination, and equality. This abandonment of constitutional imperatives is evident in a variety of official actions designed to either condone or facilitate the encroachment of Orthodoxy into Russia's foreign policy and consolidate the ROC's role as a "spiritual partner" to Russia's MOFA. Several of these policies are highlighted and considered below.

\subsubsection{Russian Orthodox Church-Ministry of Foreign Affairs Working Group}

In 2003, then Patriarch Alexy paid his first official visit to Russia's MOFA. ${ }^{61}$ And it is from this starting point that the two organizations have been able to develop policies related to defending and deepening Russia's "spiritual" values and the ROC's interactions overseas. At the time of this meeting, the

61 See Sergei Lavrov, Ministry of Foreign Affairs of the Russian Federation, Opening Remarks at Press Conference After Tenth Meeting of Working Group on MFA-Russian Orthodox Church Interaction (Nov. 21, 2007), available at http://www.ln.mid.ru/brp_4.nsf/e78a48070f128a7b43256999005bcbb3/528071c0 308e10e7c325739a00502525?OpenDocument (describing the first meeting of the Working Group on Interaction between the MOFA and the ROC during Patriarch Alexy II's first visit to the Ministry). 
parties agreed to establish a working group that, in Foreign Minister Lavrov's words, would enable the Church and Foreign Ministry to work "together realizing a whole array of foreign policy and international activity thrusts." 62 Cementing the ROCMOFA partnership in the form of a permanent working group struck Lavrov as natural, since such a move reflected "an age-old tradition of Russian domestic diplomacy."63

In general, the ROC-MOFA working group meets regularly, ${ }^{64}$ and sometimes in smaller subgroups, ${ }^{65}$ to discuss a range of issues including the maintenance of cultural and spiritual links with Russians abroad, the upholding of their rights, and preserving "the cultural and historic legacy of [the] Fatherland and of the Russian language." 66 In promoting these activities, Lavrov has described the ROC as nothing less than "a huge mainstay of government actions in this sector." 67 The central role of the Church is particularly evident in the execution of the Days of Russian Culture

62 Sergei Lavrov, Ministry of Foreign Affairs of the Russian Federation, Remarks at Orthodox Easter Reception, Moscow (Apr. 30, 2008) [hereinafter Lavrov Remarks], available at http://www.ln.mid.ru/BRP_4.NSF /f68cd37b84711611c3256f6d00541094/061ff2b937bfeb62c3257440002637f9?OpenD ocument (describing the foreign policy collaborations of the ROC and the MOFA, which include supporting and defending the rights of Russian citizens abroad and preserving Russia's cultural heritage).

63 Id.

64 See 15th Session of the Working Group for Cooperation Between the Russian Ministry of Foreign Affairs and the Russian Orthodox Church, DEP'T. FOR EXTERNAL CHURCH REL. OF THE RUSSIAN ORTHODOX CHURCH (June 4, 2010), http://www.mospat.ru/en/2010/06/04/news19967/ (describing a meeting of the ROC-MOFA working group); see also O provedenii XV zasedaniia Rabochei gruppy po vzaimodeistviiu MID Rossii I Russkoi Pravoslavnoi Tserkvi [On the $15^{\text {th }}$ Meeting of the Working Group for Cooperation of the Ministry of Foreign Affairs of the Russian Federation and the Russian Orthodox Church], Ministry OF FOREIGN AFF. OF THE RUSSIAN FED'N (June 3, 2010), http://www.mid.ru/nsnpo.nsf /02b51979dec5f083c3257107003bb5a9/c3257107002ea4a3c32577370051e422?Open Document (explaining that the Working Group meeting on June 3, 2010 primarily discussed business that had transpired since its previous meeting).

65 See Working Group for Cooperation Between Russian Orthodox Church and Foreign Ministry Meets in a Sub-group, DeP'T. FOR EXTERNAL CHURCH ReL. OF THE RUSSIAN ORTHODOX CHURCH (Apr. 15, 2010), http://www.mospat.ru/en /2010/04/15/news16869/ (relating that, at its April 15, 2010 meeting, the Working Group met in small groups to discuss various issues, including the ROC's presence in South America).

66 Lavrov Remarks, supra note 62.

67 Id. 
program, one project managed by the working group and discussed at greater length below.

More specifically, the meetings serve as strategy sessions that address the planning of the Patriarch's international travels and evaluate the ROC's activities in international organizations, as well as developments in its inter-religious relations, including with the Vatican. ${ }^{68}$ From this vantage point, the Church's past and future actions are coordinated (and possibly modified) based on implications for-and advantages to-Russia's "secular" foreign policy. In this manner, the Church and MOFA operate in tandem to advance the state's foreign policy goals, including, for example, giving the ROC and "traditional" religious values greater prominence within the international system. ${ }^{69}$

At the same time, the existence of the working group is another tangible reminder of the ROC's special treatment, the inequality of other religious faiths, and the state's failure to abide by its constitutional obligations. This is particularly evident when the substantive sessions of the ROC-MOFA working group are juxtaposed with the apathetic and intermittent efforts of MOFA's advisory council on cooperation with Muslim organizations. ${ }^{70}$ The latter group has met only a handful of times since its establishment in June 2007,71 and has limited its discussions to the status and prospects of Islamic education, ${ }^{72}$ and problems encountered by Russian Muslims during the hajj to Saudi Arabia. ${ }^{73}$

68 See O provedenii XIII zasedaniia Rabochei gruppy po vzaimodeistviiu Russkoi Pravoslavnoi Tserkvi i Mimisterstva inostrannykh del Rossiiskoi Federatsii [13 th Meeting of the Working Group on the Interaction of the Russian Orthodox Church and the Ministry of Foreign Affairs of the Russian Federation], DEP'T. FOR EXTERNAL CHURCH REL. OF THE RUSSIAN ORTHODOX CHURCH (June 29, 2009), http://www.mospat.ru/ru/2009/06/29/news3451/ (describing the Working Group's June 29, 2009 meeting, in which the group expressed satisfaction with the ROC and the Catholic Church's collaborations and suggested that the election of Metropolitan Kirill as Patriarch of Moscow would strengthen the ROC's position internationally).

69 See id. (discussing the international activities of the ROC and the Catholic Church and stressing the importance of taking certain steps to enhance the position of the ROC in the international arena).

70 Official publicly available information on this body is scant.

71 Diplomacy Needs a Moral Foundation, supra note 45, at 5.

72 See MID Rossii ysilivaet vzaimodeistvie s religioznymi organizatsiami [Russia's Foreign Ministry Strengthens Cooperation with Religious Organizations], RUSSIA MufTIS COUNCIL (Oct. 16, 2007), http://www.muslim.ru/1/news/1/333.htm 


\subsubsection{Russkiy Mir Foundation: A Chimera State-Church Foreign Policy Tool}

In addition to the collaboration growing out of the ROC-MOFA working group, the government and Church have established additional avenues for coating Russia's foreign policy with a veneer of Orthodoxy. The Russkiy Mir (Russian World) Foundation 74 is a quasi-governmental institution 75 established by Vladimir Putin in 2007 under presidential decree. According to Putin:

The Russian language not only preserves an entire layer of truly global achievements but is also the living space for the many millions of people in the Russian-speaking world, a community that goes far beyond Russia itself . . . . In my view, we need to support the initiative put forward by Russian linguists to create a National Russian Language Foundation, the main aim of which will be to develop the Russian language at home, support Russian language study

(stating that, at its October 16, 2007 meeting, MOFA's advisory council on cooperation with Muslim organizations limited its discussion to organizational issues and Muslim education); see also $\mathrm{O}$ zasedanii Konsul'tativnoho soveta po vzaimodeistviiu MID Rossii s rossiiskimi musul'manskimi organizatsiiami [Press Release on the Meeting of the Russian Foreign Ministry Advisory Council for Cooperation with Russian Muslim organizations], MINISTRY OF FOREIGN AFF. OF THE RUSSIAN FED'N (Mar. 27, 2008), http://www.mid.ru/nsdgpch.nsf/4a1c577d2fc577b843256b5f0029f67e/432569ee00522d3cc32574190044ab f5?OpenDocument (relating that, at its March 27, 2008 meeting, the Advisory Council on the Interaction of the Russian Foreign Ministry with Russian Muslim organizations discussed the religious education of Russian Muslims).

73 See O zasedanii Konsul'tativnogo soveta po vzaimodeistviiu MID Rossii s rossiiskimi musul'manskimi organizatsiiami [Press Release on the Meeting of the Advisory Council for Cooperation with the Russian Foreign Ministry and Russian Muslim organizations], Ministry of Foreign AfF. OF THE Russian FeD’N (Mar. 27, 2008),

http:/ / www.ln.mid.ru/bl.nsf/plnv/9C1FBF1097299B8AC3257419004EA576/\%24 FILE/27.03.2008.doc (detailing challenges faced by Russian Muslims).

74 The Russian word "mir" also means "peace" and "community."

75 It might also be considered a government-organized nongovernmental organization, or GONGO. 
programs abroad and generally promote Russian language and literature around the world. ${ }^{76}$

The foundation's purpose is to "promot[e] the Russian language, as Russia's national heritage and a significant aspect of Russian and world culture, and [to support] Russian language teaching programs abroad."77 More broadly, Russkiy Mir's mission statement provides for "supporting, enhancing and encouraging the appreciation of Russian language, heritage and culture" by "showcas[ing] vibrant examples of Russian art and culture around the world" in the form of "artistic, musical, literary, and scientific contributions" by Russia's "talented writers, artists and academics spreading and uniting Russian language and culture ...." 78

The Russian government retains significant ties to Russkiy Mir because it operates as "a joint project of the Ministry of Foreign Affairs and the Ministry of Education and Science and [is] supported by both public and private funds."79 At the foundation's 2009 annual meeting, a statement by Prime Minister Putin hailed the "close cooperation established between the foundation and the government." 80 To be certain, this high level of cooperation is ensured by the presence of Foreign Minister Lavrov, Andrei Fursenko, Minister of Education and Science, and Sergey Vinokurov, Head of President Medvedev's Office for Interregional and Cultural Relations with Foreign Countries, on Russkiy Mir's board of trustees. ${ }^{81}$

Coupled with its governmental linkage, the foundation also has developed an increasingly obvious connection with the ROC. The

76 About Russkiy Mir Foundation: Creation, RUSSKIY MIR FOUND., http://www.russkiymir.ru/russkiymir/en/fund/about (last visited Nov. 17, 2011).

77 Id.

78 About Russkiy Mir Foundation: Mission Statement, RUSSKIY MIR FOUND. http://www.russkiymir.ru/russkiymir/en/fund/about (last visited Nov. 17, 2011) (explaining the Foundation's mission to promote peace and understanding by encouraging the appreciation of the Russian language and culture).

79 About Russkiy Mir Foundation: Creation, supra note 76.

80 The Third Russkiy Mir Assembly: Summary of Results, RUSSKIY MIR FOUND. (Nov. 5, 2009), http://www.russkiymir.ru/russkiymir/en/news/fund /news0025.html.

81 See Board of Trustees, RUsSKIY MIR FOunD., http://www.russkiymir.ru/russkiymir/en/fund/board.html (last visited Nov. 17,2011 ) (listing the members of the board of trustees). 
Russian language version of the Russkiy Mir website elaborates no less than seventeen main objectives of the foundation (beyond those cited above), including, at the very end of the list, interaction with the Russian Orthodox Church and other religions in promoting the Russian language and Russian culture. ${ }^{82}$ As an outgrowth of this, much of the content posted to Russkiy Mir's website is Orthodoxy-driven, consisting of entries seemingly unrelated to the mandate of advancing the Russian language. These stories carry headlines such as: “Russia's Patriarch Visits Azerbaijan," 83 "Days of Russian Spiritual Culture Kick off in Vatican," 84 "Orthodox Christians Celebrate Feast of the Resurrection of Christ in Argentina," 85 "Patriarch Kirill to Visit Northwest Russia," 86 "Metropolitan Hilarion Signals Hope for Meeting between Moscow Patriarch and Pope," 87 and "Patriarch Kirill Interested in Space Travel." 88

At first blush, Russkiy Mir's mandate entails little or no connection to the promotion of spirituality or religion. As noted, the foundation is ostensibly focused on the seemingly secular task of promoting the Russian language and related teaching programs

82 See O Fonde [About the Foundation], RUSSKIY MIR FOUND., http://www.russkiymir.ru/russkiymir/ru/fund/about (last visited October 24, 2011) (stating the "Russkiy Mir's" statute and listing its objectives). There is no parallel reference to the ROC on Russkiy Mir's English language webpage (detailing the objectives found on the Russian language website); see also About Russkiy Mir Foundation: Mission Statement, supra note 78 (listing objectives found on the English language website).

83 Russia's Patriarch Visits Azerbaijan, RUSSKIY MIR FOUnD. (Apr. 26, 2010), http://www.russkiymir.ru/russkiymir/en/news/common/news0279.html.

84 Days of Russian Spiritual Culture Kick off in Vatican, RUSSKIY MIR FOUND. (Feb. 12, 2010), http://www.russkiymir.ru/russkiymir/en/news/common /news0092.html.

85 Prazdnik Voskreseniia Xristova pravoslavnye otmechali v Argentine [Orthodox Christians Celebrate the Feast of the Resurrection of Christ in Argentina], RUSSKIY MIR FounD. (May 4, 2010), http://admin.russkiymir.ru/russkiymir/ru/news /common/news9015.html.

86 Patriarch Kirill to Visit Northwest Russia, RussKIY MIR Found. (May 28, 2010), http://www.russkiymir.ru/russkiymir/en/news/common/news0423.html.

87 Metropolitan Hilarion Signals Hope for Meeting between Moscow Patriarch and Pope, RUSSKIY MIR FOUND. (May 20, 2010), http://www.russkiymir.ru/ russkiymir/en/news/common/news0385.html.

88 Patriarch Kirill Interested in Space Travel-Roscosmos Chief, RUSSKIY MIR Found. (Dec. 2, 2010), http://www.russkiymir.ru/russkiymir/en/news /common/news1755.html. 
abroad. 89 Moreover, at Russkiy Mir's inception in 2007, no ROC representatives were included either on the organization's founding executive staff or board of trustees. ${ }^{90}$ Despite this apparent disconnect, Putin's NSC from 2000 explicitly foreshadowed the linkage between language and Russia's "spiritual renewal" put into practice by Russkiy Mir:

The spiritual renewal of society is impossible without the preservation of the role of the Russian language as a factor of the spiritual unity of the peoples of multinational Russia and as the language of interstate communication between the peoples of the member states of the Commonwealth of Independent States. ${ }^{91}$

The NSC's vision demonstrates that the ROC's connection to Russkiy Mir is not simple kismet, but rather part of a longstanding, long-term vision originally espoused by Putin and continued today under the Medvedev administration: Orthodoxy shall be promoted not only under the banner of an ostensibly more inclusive notion of spirituality or culture, but also as part of the government's broader effort to safeguard the Russian language. Taking a deeper look at Russkiy Mir's most recent interactions with the ROC, it becomes obvious that the relationship is intensifying as the foundation drifts away from its core mission of promoting the Russian language and wanders into the realm of

89 See Decree of the President of the Russian Federation on the Establishment of the Russkiy Mir Foundation, RUSSKIY MIR FOUND. (June 21, 2007), http://www.russkiymir.ru/russkiymir/en/fund/index.nested/decree_text.html (establishing that the Foundation was formed in order to promote Russian language and culture and to start Russian language teaching programs in other countries); Ukaz Presidenta Rossiiskoi Federatsii O sozdanii fonda "Russkiy mir" [Presidential Decree on the Creation of the "Russian World" fund], No. 796 (June 21, 2007), http://www.rg.ru/2007/06/23/fond-dok.html (stating that the creation of a "Russian World" fund is desirable because the fund could help promote the Russian Language).

90 Decree of the President of the Russian Federation on the Establishment of the Russkiy Mir Foundation, supra note 89 (setting the procedure of organizing "Russkiy Mir" without the use of representatives of the Russian Orthodox Church in the founding executives or trustees).

91 See National Security Concept of the Russian Federation, supra note 9, at pt. IV (restating that use of the generic term "spiritual" in this context operates for the express purpose of solidifying-with the assistance of state fundingOrthodoxy's profile and proximity to the Russian government); see also supra 3.1.1. 
endorsing an exclusively Orthodox version of spirituality and Russia abroad.

Given this dynamic, Russkiy Mir is a virtual petri dish for examining the explosion of ROC-state cooperation on the international stage, an exercise that is revealing on a number of levels. First, to the extent that Russkiy Mir has undertaken activities falling outside the scope of its government-sanctioned (and financed) mandate, it is technically - if rather ironically - in violation of Russia's heavy-handed NGO law, and therefore potentially subject to liquidation under the provisions of that law..$^{92}$ Second, in light of the government's intimate connection to the foundation, these activities give rise to a potential breach of the government's constitutionally mandated obligations towards secularism, church-state separation, and equality among religious faiths. Finally, in light of Russkiy Mir's emphasis on operations outside of Russia, the foundation-and by implication the government of Russia - serves to advance the ROC's religious and political interests by disseminating an exclusively Orthodox point of view and cementing the linkage between Orthodoxy and the state.

At the end of 2009, Russkiy Mir and the ROC entered into a formal cooperation agreement ${ }^{93}$ intended to solidify systematic collaboration. This milestone agreement calls for inter alia "strengthening the spiritual unity of the Russian world," 94

92 The example of Russkiy Mir also underscores the arbitrariness associated with Russia's enforcement of the NGO law. For a detailed analysis of the law and its human rights implications, see Blitt, supra note 21.

93 Plans for an agreement emerged following an August 2009 meeting between Patriarch Kirill and Russkiy Mir Foundation director Vyacheslav Nikonov. A signing event was held on Nov. 3, 2009, at the Russkiy Mir Foundation's third annual assembly. See Sviateishii Patriarkh Kirill vstretilsia s rukovoditelem fonda "Russkiy Mir" V.A. Nikonovym [Patriarch Kirill met with the head of the "Russian World" foundation], PATRIARCHIA (Aug. 26, 2009), http://www.patriarchia.ru/db/text/727913.html (reporting that an agreement had been reached to pursue "systematic cooperation and collaboration").

94 See Zhurnaly zasedaniia Sviashchennoho sinoda ot 25 dekabria 2009 goda [Holy Synod Journals, Dec. 25, 2009], RUSSKIY MIR FounD. (Dec. 28, 2009), http://www.russkiymir.ru/russkiymir/ru/fund/press/press1419.html

(resolving that the agreement between the ROC and Russkiy Mir was a beneficial one for the "strengthening of the spiritual unity of the Russian world"); Podpisano soglashenie o sotrudnichestve mezhdu Russkoi pravoslavnoi tserkov'iu i Fondom "Russkiy Mir" [An agreement on cooperation between the Russian Orthodox Church and the Foundation "Russkiy Mir" is signed], RUSSKIY MIR FOUND. (Mar. 11, 2009), 
preserving the "spiritual, linguistic and cultural identity" of Russians abroad,95 and promoting structures created by the Moscow Patriarchate overseas, ${ }^{96}$ including the organization of tours to Orthodox pilgrimage sites outside of the Russian Federation. ${ }^{97}$ The agreement also acknowledges the importance of the ROC's foreign activities, ${ }^{98}$ mandates that ROC representatives will be appointed to Russkiy Mir's grant-making council and board of trustees, ${ }^{99}$ and establishes a permanent working group of ROC and Russkiy Mir representatives to address any practical issues that may arise in implementing the agreement. ${ }^{100}$

http://www.russkiymir.ru/russkiymir/ru/news/fund/news0177.html

(describing the procedure of signing the agreement and stating Kirill's positions on the importance of this cooperation and the existence of Russkiy Mir).

95 See Podpisano soglashenie o sotrudnichestve mezhdu Russkoi Pravoslavnoi Tserkov'iu i fondom "Russkiy mir" [An agreement on cooperation between the Russian Orthodox Church and the Foundation "Russian World"], DEP'T FOR EXTERNAL CHURCH REL. OF THE RUSSIAN ORTHODOX CHURCH (Nov. 3, 2009), http://www.mospat.ru/ru/2009/11/03/news7705/ (outlining the content of the agreement between the ROC and Russkiy Mir).

96 See Zakliucheno soglashchenie mezhdu patriarhom Kirillom I fondom "Russkiy mir" [Agreement between Patriarch Kirill and "Russian World" Foundation], RusSKIY MIR FOUND. (Nov. 3, 2009), http://www.russkiymir.ru/russkiymir/ru /fund/press/press1041.html (describing the particulars of the agreement between the ROC and Russkiy Mir, including the promotion of structures created by the Moscow Patriarchate in overseas institutions).

97 See An agreement on cooperation between the Russian Orthodox Church and the Foundation "Russian World," supra note 95 (stating that the joint work of the fund and Church will organize pilgrimages to Russian shrines and memorial sites abroad).

98 Id. (describing that the ROC sees its foreign activities as significant for preserving the Russian world and caring for "the flock").

99 See Agreement Between Patriarch Kirill and "Russian World" Foundation, supra note 96 (describing the participation of the ROC in Russkiy Mir governance). At present, the Orthodox Church enjoys a monopoly as the sole religious organization bestowed with a seat on the Foundation's board of trustees. Metropolitan Hilarion, Chairman of the Moscow Patriarchate Department for External Church Relations, represents the Church in this capacity. See Board of Trustees, supra note 81.

100 See An agreement on cooperation between the Russian Orthodox Church and the Foundation "Russian World," supra note 95 (describing the creation of a working group for problem resolution as part of the signed agreement). The working group responsible for managing ROC-Russkiy Mir Foundation relations held its first meeting in April 2010. It is expected that the group will continue meeting periodically to address practical matters relating to the ongoing relationship. See Sostoialos zasedanie Rabochei gruppy po vzaimodeistviu Russkoi Pravoslavnoi Tserkvi I Fonda [A meeting of the Working Group on the Interaction of the Russian Orthodox 
The actual signing of the agreement was an occasion weighty enough to merit Patriarch Kirill's participation ${ }^{101}$ and to be scheduled during the foundation's third annual assembly, an event "attended by nearly a thousand people from 80 countries."102 In his remarks to the crowd, Kirill shared his views on the future of Russian culture and the Russian world. He explained that Russkiy Mir's efforts around the world serve as a bulwark against the threat of globalization and the loss of culture. He also emphasized that the ROC represents the "backbone of the Russian world" and serves as a unifying force inside and outside of Russia that prevents assimilation and fosters closer ties with the Russian state. ${ }^{103}$ Notably, Kirill stressed his belief that the ROC was not an ethnic church but rather culturally based, and advocated for use of the umbrella term "countries of the Russian world" to designate all those states that might be home to a significant Russian minority population. ${ }^{104}$

Russkiy Mir's newly minted and far-reaching formal alliance with the ROC places the government into a constitutionally untenable position. In light of its direct financial and political support for the foundation, the government has in essence created and sanctioned a proxy body that represents nothing less than a fusion of Orthodox and state institutions. This chimera, originally tasked with the modest goal of showcasing examples of Russian art and culture, is now the perfect embodiment of how Russia's foreign policy is conducted with utter disregard for the

Church and the Foundation "Russian World"], DEP'T FOR EXTERNAL CHURCH REL. OF THE RUSSIAN ORTHODOX CHURCH (Apr. 22, 2010), http://www.mospat.ru/ru/2010/04/22/news17159/ (discussing the agreement on cooperation between the Russian Orthodox Church and the Foundation "Russian World").

101 Low-level delegates from the ROC delivered statements on behalf of Patriarch Alexy II to previous Russia World Assemblies in 2007 and 2008. See Assamblei russkogo mira [Russian World Assemblies], RUSSKIY MIR FOUND. (archival copy on file with the University of Pennsylvania Journal of International Law) (linking to press releases of prior years' Russia World Assemblies).

102 The Third Russkiy Mir Assembly, supra note 80.

103 See id. (summarizing the remarks of Patriarch Kirill, which focused on the ability of the Russian Orthodox Church to prevent the globalization's threat of a "merg[ing] of all cultures ....").

104 See Agreement between Patriarch Kirill and "Russian World" Foundation, supra note 96 (describing Patriarch Kirill's characterization of the Russian Orthodox Church and its relation to countries with Russian-speaking populations). 
constitutional requirements of secularism and religious equality. Not surprisingly, at least one media source has labeled Russkiy Mir as "one of the structural divisions of Russia's Foreign Intelligence Service."105 Notably, Vyacheslav Nikonov, the foundation's director, has a personal connection to Russia's secret service, having served as advisor to the director of the KGB in the early 1990s. ${ }^{106}$

\subsubsection{Support for Days of Spiritual Culture}

One of the specific projects coming out of the ROC-MOFA working group is the Days of Russian Spiritual Culture. This program, part of a broader "Days of Russia" PR initiative launched by the Russian government, is operated with support from Russia's MOFA, the Ministry of Culture, and the ROC, among others.107 To date, the program has been a traveling roadshow of sorts, held in over a dozen states including Serbia, Croatia, Cuba, Costa Rica, Venezuela, Brazil, Argentina, and Chile. ${ }^{108}$ In 2010, the Vatican hosted a similar program, which included an

105 The same report notes that Russkiy Mir's executive director was formerly assistant director of the KGB. See Alexander Gavrosh, Zakarpats'kogo separatysta finansuie Moskva [Moscow Supports Separatist Transcarpathia], UKRAYINA MOLODA, Nov. 8, 2009, http://www.umoloda.kiev.ua/number/1285/180/45461/ (noting that Nikonov's career began in the KGB); see also OSC [US Open Source Center] Analysis: Russia Promotes Rusyn Separatism in Western Ukraine, Jan. 5, 2009, (quoting UKRAYINA MOLODA article, in JOHNSON'S RUSSIA LIST, 2009-\#3, Jan. 6, 2009).

106 This information is only available on the Russian language version of the Russkiy Mir website. See Administration, RUSSKIY MIR FOUND., http://www.russkiymir.ru/russkiymir/ru/fund/administration/nik.html (last visited Nov. 19, 2011) (outlining Nikonov's biography and work history); see also Russia Profile, Background People, http://russiaprofile.org/bg_people /resources_whoiswho_alphabet_n_nikonov.html (last visited Nov. 19, 2011) (entry for Nikonov Vyacheslav Alexseevich, President of the Polity Foundation) (detailing the career path of Vyacheslav Nikonov).

107 See Days of Russia to Take Place in Latin America for First Time, RUSSKIY MIR Found. (Oct. 9, 2008) http://www.russkiymir.ru/russkiymir/en/news /common/news0115.html (describing the celebration, Days of Russia, taking place in Cuba, Costa Rica, Venezuela, Brazil, Argentina, Chile, and Paraguay).

108 See Latin America to Celebrate the Days of Russian Spiritual Culture, INTERFAX (Sept. 30, 2008), http://www.interfax-religion.com/ ?act=news\&div $=5210$ (announcing the upcoming Days of Russian Spiritual Culture, along with some details of the event); see also Days of Russian Spiritual Culture in Serbia, THE VOICE OF RUSSIA (Sept. 15, 2010, 8:30 PM), http://english.ruvr.ru/2010/09/15/20596562.html (reporting on the Days of Russian Spiritual Culture in Serbia). 
"international theological forum . . . devoted to the common Christian roots of the Roman Catholic and the Eastern Orthodox Churches and the common tasks they are facing in today's Europe."109

According to Foreign Minister Lavrov, the Days of Russian Spiritual Culture program offers "a series of meetings, exhibitions, film showings and concerts" and "joint divine services" 110 to help acquaint others with Russian spiritual culture. Putting aside the question of whether the foreign ministry is operating ultra vires of Russia's constitution by actively promoting religious services, Lavrov's description conveniently ignores the fact that the program is wholly Orthodox in orientation and directly links the Moscow Patriarchate and state to the exclusion of all other faiths existing in Russia today. ${ }^{111}$

More accurately, a program organizer describes the overriding intent of the Days of Russian Spiritual Culture exhibit to generate "positive public opinion" about the reunification of the ROC and the ROCOR, and highlight the revival of Orthodoxy and the restoration of its holy sites in Russia.112 A press releasecoincidentally published by Russkiy Mir-explains that the "exhibition highlights the life of Russian churches today and spiritual development in society, the revival of sacred sites and the

109 Days of Russian Spiritual Culture Start at the Vatican, RUSSKIY MIR FOUND. (May 19, 2010), http://www.russkiymir.ru/russkiymir/en/news/common /news0381.html. See also Vatican to Hold Days of Russian Spiritual Culture, INTERFAX (Feb. 12, 2010, 12:49 PM), http://www.interfax-religion.com / ?act=news\&div=6928 (describing the Days of Russian Spiritual Culture program in the Vatican and the shared sentiments and values of the Eastern and Western Churches); Days of Russian Spiritual Culture Kick off in Vatican, RUSSKIY MIR FOUND. (Feb. 12, 2010), http://www.russkiymir.ru/russkiymir/en/news/common /news0092.html (reporting on Patriarch Kirill's assessment of the state of European cultural identity and what can be done to remedy the problems found therein).

110 Lavrov Remarks, supra note 62.

111 Remarkably, Lavrov in the same breath goes on to describe Russia as having "for centuries existed as a multinational and multiconfessional society . . ." Id.

112 See Latin America to celebrate the Days of Russian Spiritual Culture, supra note 108 (quoting the organizers of Russian Days of Spiritual Culture in Latin America as saying the purpose of the event is to form "positive public opinion about reunion of the Russian Orthodox Church in Russia and Abroad"). 
historic significance of the Russian Orthodox Church Outside Russia and its reunification with the Moscow Patriarchate."113

Beyond concerts by the Sretensky Monastery Choir for the "secular public", the Foreign Ministry's sponsorship of the program has facilitated sales of Orthodox literature published by the Moscow Patriarchate ${ }^{114}$ and acquainting believers in Latin America with "modern Russian Orthodoxy."115 When viewed from the ground level, the Foreign Ministry's support for Days of Russian Spiritual Culture has in fact embroiled the Russian government directly in the work of supporting the ROC proselytizing abroad. To illustrate this conclusion, consider an excerpt from an interview with Father Alexy Aedo, a Chilean native and Orthodox archpriest:

Hieromonk Paul Scherbachev: What kind of mark have these days [of Russian Spiritual Culture] left in the souls of those Chileans who are still not in the Church, who consider themselves to be secular people? From your point of view, could it happen that, after visiting the concerts of Sretensky Monastery's choir, the exhibition 'Holy Russia, Orthodox Russia[]', and the cinematic festival of Russian films, there will be awakened in them an interest in spirituality, and in true Russian culture, which is closely bound up with the idea of Orthodoxy?

Father Alexy Aedo: Of course. I think this [program] will also help them draw closer to the Orthodox faith because during this period of the Days of Russian culture, Chileans have had the chance to converse with clergy - with priests and hierarchs ... people may be very far from the Church, perhaps not even believe in God ... until they become

113 Days of Russia to Take Place in Latin America for First Time, supra note 107; see also Days of Russian Spiritual Culture Start at the Vatican, supra note 109 (describing a seminar to be held at the event devoted to the common roots of the Vatican and the Russian Orthodox Church).

114 See V latinskoi Amerike proidut Dni russkoi duhovnoi kul tury [Days of Russian Spiritual Culture to be Held in Latin America], INTERFAX (Sept. 29, 2008, 2:08 PM), http://www.interfax-religion.ru/?act=news\&div=26699 (discussing the worship services to be held during the Russian Days of Spiritual Culture in Latin America and the accompanying literature).

$115 \mathrm{Id}$. 
acquainted with a priest. The Lord God literally opens for them a little door, tiny and unnoticeable; and-lo!-faith appears. Such a person suddenly turns to us with a request to bless his home, to bless his children. Then he learns about the heights of monastic life, and is beside himself with joy and wonder about it. He starts reading the lives of saints-Seraphim of Sarov, Silouan of Mount Athos, Herman of Alaska, and other ascetics of piety. . .By God's grace, a person talks with a priest and finds the footsteps of the Lord. 116

In addition to actively sponsoring the ROC's missionary efforts, the Days of Russian Spiritual Culture serves the purpose of advancing Russia's temporal foreign policy. According to Dmitry Kravtsov, director of "Russia House" in Buenos Aires, the program is important because it works to strengthen Russia's public diplomacy abroad.117 Mixed in with the icons and clergy, activities include sessions on promoting regional cooperation, strategic partnership and profitable investments. ${ }^{118}$ From this perspective,

116 Hieromonk Paul Scherbachev, Opening a Door for the Lord in People's Hearts: An interview, THE VOICE OF ORTHODOXY (Jan-Feb, 2009), http://www.thevoiceoforthodoxy.com/archives/articles/Opening_door_peoples _heart.html\#_ftnref4.

117 See Dni russkoi duhovnoi kul tury v argentinskoi provintsii Santa-kruz [Days of Russian Spiritual Culture In the Argentine Province of Santa Cruz], PRAVOSLAVIE (Feb. 10, 2010), http://www.pravoslavie.ru/news/34001.htm (discussing the opening ceremony and celebration of Russian Days of Spiritual Culture with the participation of Argentina, which are meant to develop and sustain the social, cultural, educational, and spiritual relations between Russian and Argentina); Días de la cultura espiritual rusa en la provincia Santa Cruz [Days of Russian Spiritual Culture in the Province of Santa Cruz], CASA DE RUSIA (Feb. 2, 2010), http://www.casaderusia.org/ar/ficha-evento.php?idxevent=62 (outlining the ways in which the Russian Days of Spiritual Culture are meant to develop relations between Russian and Argentina). It is worth noting that "Russia House" in Buenos Aires, operated by the Federal Agency for the Affairs of the Commonwealth of the Independent States (CIS) of Compatriots Living Abroad and for International Humanitarian Cooperation (Rossotrudnichestvo), prominently features dedicated links to Russian Orthodox Church news and messages on its homepage, available in Russian and Spanish. See, e.g., http://www.casaderusia.org/ and http://www.casaderusia.org/ar/index.php. The director of Rossotrudnichestvo is also a member of the Russkiy Mir's board of trustees. See supra note 74.

118 See Days of Russia to Take Place in Latin America for First Time, supra note 107 (describing some of the activities of the Russian Days of Spiritual Culture). 
the Days of Russian Spiritual Culture initiative crystallizes the synthesis between Russia's foreign policy objectives and the dissemination of Orthodoxy.

\subsubsection{Facilitating an Exclusive Podium for Orthodoxy at the United Nations}

\subsubsection{Sponsoring the Spiritual Revival of Russia Exhibit}

The Russian MOFA also has sought to establish a prominent role for the Moscow Patriarchate within a variety of U.N. fora. Similar to the Days of Russian Spiritual Culture program described above, Russia's Permanent Mission to the U.N. sponsored an exhibit at the U.N. Headquarters in New York entitled "Russian Orthodox Church and Interreligious Dialogue: Spiritual Revival of Russia."119 While the title purported to emphasize "interreligious dialogue," the event's production and content reflected a transparent effort to undercut Russia's constitution and legitimize ongoing discrimination against so-called "nontraditional" religions in Russia. Then Patriarch Alexy's remarks at the opening ceremony glaringly excluded thousands of pious Russian citizens by proclaiming "we, Russian Orthodox Christians, Muslims, Judaists, and Buddhists, live in peace. And at the heart of this peace is our respect for each other's traditions, ways of life and social models." 120

Not to be outdone, Vitaly Churkin, Russia's Permanent Representative to the United Nations, affirmed this exclusionary and disingenuous view when he boasted that his Mission "wanted to show how modern Russia is addressing the challenging task of promoting interreligious and intercultural understanding." 121 This

119 Press Release, Permanent Mission of the Russian Fed'n to the U.N., On the opening at the U.N. Headquarters of the photo exhibition "Russian Orthodox Church and Interreligious Dialogue: Spiritual Revival of Russia" (Oct. 8, 2007), available

http://www.un.int/russia/new/MainRoot/docs/press/071008eprel.htm.

120 Id.

121 Press Release, H.E. Vitaly Churkin, Permanent Representative of the Russian Fed'n to the U.N., Talking Points at the Opening of the Photo Exhibition "Russian Orthodox Church and Interreligious Dialogue: Spiritual Revival of Russia" (Oct. 4, 2007), available at http://www.un.int/russia/new/MainRoot/docs/press/041007eprel.htm. 
brash statement came only months after the European Court of Human Rights ruled that Russia's effort to deny re-registration to the Salvation Army on the basis that it was a "paramilitary organization" amounted to an unjustifiable interference with the right to freedom of religion and association under the ECHR. ${ }^{122}$ Churkin also hailed the "major and truly selfless role in the quest for interreligious harmony ... played by the Russian Orthodox Church" despite longstanding evidence that the Church "exerted pressure on [Russia's Justice] Ministry to prevent some religious organisations from obtaining their registration." 123 In the end, as if to underscore the point, the ROC was the only religious group directly involved in the exhibit's planning, and reference to activities of religious NGOs in Russia was limited to those with consultative status at the United Nations-coincidentally two Russian Orthodox groups: the World Russian People's Council ${ }^{124}$ and the Imperial Orthodox Palestine Society. ${ }^{125}$

122 The Court inter alia found "no reasonable and objective justification for a difference in treatment of Russian and foreign nationals as regards their ability to exercise the right to freedom of religion through participation in the life of organised religious communities." Further, the Court rejected the Moscow Justice Department's denial of registration on the basis that the Salvation Army represented a "paramilitary organisation," reiterating that "the right to freedom of religion as guaranteed under the Convention excludes any discretion on the part of the State to determine whether religious beliefs or the means used to express such beliefs are legitimate." Moscow Branch of the Salvation Army v. Russia, paras. 82, 91 App. No. 72881/01, (2006-XI Eur. Ct. H.R.), available at http://www.eclj.org/PDF/06100506_THE_SALVATION_ARMY_v_RUSSIA_JU DGMENT.pdf.

123 EUR. PARL. Ass., Report by the Monitoring Comm. on Honouring of Obligations and Commitments by the Russian Fed'n, Doc. No. 9396, para. 99 (2002), http://assembly.coe.int/Documents/WorkingDocs/doc02/EDOC9396.htm. See also EUR. PARL. Ass., Resolution 1278: Russia's Law on Religion, 11th Sess., para. 6(i) (2002), http://assembly.coe.int/Main.asp?link=/Documents/AdoptedText/ta02 /ERES1278.htm (The Parliamentary Assembly subsequently recommended a more uniform application of Russia's religious laws "throughout the Russian Federation, ending unjustified regional and local discrimination against certain religious communities and local officials' preferential treatment of the Russian Orthodox Church, and in particular their insisting in certain districts that religious organisations obtain prior agreement for their activities from the Russian Orthodox Church").

124 It is common knowledge that the World Russian People's Council (WRPC) is an NGO established and controlled by the ROC to promote its agenda on the international level. The ROC Patriarch serves as the WRPC leader and the NGO's head office is located on the grounds of the Danilov Monastery, headquarters of the Moscow Patriarchate and the official residence of the Russian Patriarch. See 


\subsubsection{Supporting the Establishment of a U.N. Consultative Council on Religions}

In 2007, at the urging of the Moscow Patriarchate to have its role at the United Nations increased, Russia's MOFA:

came up with the initiative for establishing a consultative council on religions ... to develop recommendations for the settlement of interconfessional problems in different regions of the world and to help enhance the activities and authority of the U.N. in questions of the maintenance of security and protection of human rights. ${ }^{126}$

During the U.N. General Assembly's sixty-second session, foreign minister Lavrov labeled the "spiritual and moral foundations of human solidarity" increasingly vital:

World Russian People's Council to Discuss Problems of Russian Education and Family, INTERFAX (Apr. 23, 2010, 5:37 PM), http://www.interfaxreligion.com/?act=news\&div=7193 (announcing the opening of the $14^{\text {th }}$ World Russian People's Council); Moscow.InFO, The Danilov Monastery, http://www.moscow.info/orthodox-moscow/danilov-monastery.aspx (last visited Nov. 18, 2011) (describing the Danilov Monastery as the official residence of the ROC Patriarch); see also SACREd Destinations, Danilov Monastery, Moscow, http://www.sacred-destinations.com/russia/moscow-danilov-monastery.htm (last visited Nov. 18, 2011) (supplying a historical primer on the Danilov Monastery and its importance to the ROC); U.N. Econ. \& Soc. Council [ECOSOC], List of non-governmental organizations in consultative status with the Economic and Social Council as of 1 September 2010, U.N. Doc. E/2010/INF/4 (Sept. 1, 2010), available at http://csonet.org/content/documents/E2010INF4.pdf (citing WRPC as holding special consultative status with ECOSOC since 2005).

125 See Press Release, Permanent Mission of the Russian Fed'n to the U.N., supra note 119 (identifying the Imperial Orthodox Palestine Society as a special status NGO that was a part of the photo exhibition); Press Release, Ministry of Foreign Aff. of the Russian Fed'n, Transfer to the Imperial Orthodox Palestine Soc'y (IOPS) of a Land Plot in Bethlehem (May 22, 2008), available at http:/ / www.ln.mid.ru/brp_4.nsf/0/a75314297cc77bd2c3257451005748b3?OpenD ocument (showing the continued close relationship between the Russian government and IOPS); see generally About Us, THE IMPERIAL ORTHODOX PALESTINE SOCIETY - PALESTINE, http://www.iops.ps/en/about_us.htm (last visited Nov. 18, 2011) (The Imperial Orthodox Palestine Society was established "to strengthen Orthodoxy in the Holy Land [and] to help Russian visitors traveling to the Holy Land . . . ."); Hanna Kildani, MOdern Christianity IN THE Holy Land (2010), (retelling the early history of the Imperial Orthodox Palestine Society and its roots in Russia).

126 Lavrov Remarks, supra note 62. 
Spiritual values of all world religions make it imperative to achieve intercivilizational accord and fight manifestations of xenophobia and racism ... We propose . . . establishing under the United Nations auspices, a special forum - a kind of consultative Council of Religions - for the exchanges of views among representatives of major world confessions. ${ }^{127}$

Since then, Russia has consistently and repeatedly advocated in favor of such a council across a variety of international fora, 128 including directly to the U.N. Secretary-General,129 as part of a methodical effort to increase the points of entry available to the ROC on the international level and in turn boost the projection of Russian state power. According to Lavrov:

Russia supports in every way possible all efforts to fit the dialog of religions into international affairs within the framework of multilateral organizations and forums . . . . The Council's main task would be to establish a wideranging inter-religious dialog and a dialog between the representatives of different faiths and political leaders. The presence of such an international inter-religious forum is long overdue..$^{130}$

127 U.N. GAOR, 62nd Sess., 11th plen. mtg. at 17-18, U.N. Doc. A/62/PV.11 (Sept. 28, 2007). See also Moscow hopes initiative to set up a Consultative Council for Interreligious Cooperation under UN finds support, REOR STRASBOURG (Dec. 3, 2007), http://strasbourg-reor.org/?topicid=309 ("The patriarch also welcomed . . . the statement made by Mr. Lavrov at the UN 62nd session ....").

128 See Russia's Foreign Minister answers your questions exclusively, RT (Apr. 30, 2009, 4:42 PM), http://rt.com/politics/russia-s-foreign-minister-answers-yourquestions-exclusively/ ("[The Russian Government] support[s] all international initiatives aimed at promoting inter-religious concord."); Sergei Lavrov, Minister of Foreign Affairs Speech at the XIV World Russian People's Council (May 25, 2010) (transcript available at http://www.mid.ru/brp_4.nsf/english /8B9923C5CBC35FB5C325772F0022FCE0) (emphasizing the importance of the $\mathrm{ROC}$ in fostering tolerance for all people in Russia).

129 See Press Release, Minister of Foreign Aff. of the Russian Fed'n, Visit to the [sic] Russia of UN Secretary General Ban Ki-moon (Apr. 14, 2008), http://www.mid.ru/Brp_4.nsf/arh/E2BDA222903EA28DC325742B0053724A?Op enDocument ("[T]he Moscow patriarchate of the Russian Orthodox Church [described] the essence of Russia's proposal to create a consultative council of religions under the aegis of the U.N. . . . to [U.N. Secretary General] Ban KiMoon.").

130 Diplomacy Needs a Moral Foundation, supra note 45. 
The desire to establish a religious council has featured prominently as one of Russia's selling points in its bid to bolster ties with the Muslim world. In 2008, foreign minister Lavrov invited the Organization for the Islamic Conference (OIC) to back Russia's U.N. initiative. At that meeting, Prime Minister Putin emphasized the need for the interreligious council in the context of the "legitimate and growing role of the religious factor in the modernday international relations . . .."131 One former diplomat described the move as a "major political initiative," elevating Russian standing in the Muslim world to a "qualitatively new level." 132 Soon thereafter, Saudi Arabia and other Muslim states embraced Russia's proposal as part of the fourth forum of the "Russia-Islamic World Strategic Vision Group."133 The final communiqué issued by the group - which included representatives from the $\mathrm{ROC}^{134}-$ adopted a recommendation to "support the proposal by the

131 Press release, Prime Minister Vladimir Putin, Points of The Address at the XI Summit of the Organization of the Islamic Conference (March 13, 2008), available

http://www.mid.ru/Brp_4.nsf/arh/681763963FDDAC13C325740F00213D7B?Op enDocument. This approach also feeds into Medvedev's FPC. See supra Part 3.1.2 (explaining that Russia's Foreign Policy Concept of 2008 made note of the importance for Russia to have open policies towards religion beyond that of the $\mathrm{ROC})$.

132 M. K. Bhadrakumar, Russia Challenges US in the Islamic World, AsIA TIMES ONLINE (Mar. 29, 2008), http://www.atimes.com/atimes/Central_Asia /JC29Ag01.html.

133 See Press Release, President of Russia, Dmitry Medvedev Sent His Greetings to Delegates and Guests of The Fifth Meeting of The Russia-Islamic World Strategic Vision Group (Dec. 21, 2009), http://archive.kremlin.ru/eng/text/news/2009/12/223466.shtml ("[The] Strategic Vision Group was established in 2006 to broaden cooperation between Russia and the Muslim countries."). The group held its fifth meeting in December 2009. Id

134 Russia-Islamic World Group Backs Russia's Proposal to Set Up U.N. Religious Council, INTERFAX (Oct. 31, 2008, 12:35 PM), http://www.interfaxreligion.com/?act $=$ news\&div $=5327$ (indicating that ROC Archpriest Vsevolod Chaplin was present at the meeting and approved of Saudi King Abdullah's thoughts on religious tolerance). Reportedly, this was the first time an Orthodox Russian priest visited the Saudi kingdom. See A Russian Priest Visits Saudi Arabia for The First Time, INTERFAX (Oct. 29, 2008, 5:30 PM) http://www.interfaxreligion.com/?act=news\&div $=5320$ ("Archpriest Vsevolod Chaplin became the first priest of the Russian Orthodox Church in history to visit Saudi Arabia."). 
Russian Federation to establish a consultative council on religions at the United Nations." 135

As was the case with the Spiritual Revival of Russia exhibit, in the context of promoting international-level interreligious dialogue the Russian government routinely excludes representative voices from Russia's diverse religious communities. According to Lavrov, it is sufficient that Russia's MOFA maintains close contacts in U.N. bodies with religious NGOs working in cooperation with the ROC, namely "the International Foundation for the Unity of Orthodox Christian Nations, the World Russian People's Council, and the Imperial Orthodox Palestine Society."136 This exclusive subset of dialogue partners signals the government's endorsement of the view that only the ROC can serve as the legitimate representative for Russian religious consciousness on the international stage. Even within the ostensibly open-ended context of an interreligious dialogue, "nontraditional" religions are a priori excluded, and other so-called non-Orthodox "traditional" faiths must channel their views through the filter of the Moscow Patriarchate.

Support for exploiting a stilted vision of religious dialogue as a lever for boosting Russia's political power within the "polycentric international system"137 emanates from the Russian President

135 Final Communique of the Fourth Forum of the Strategic Vision Group: Russia and the Islamic World, Oct. 29, 2008, available at http://shaimiev.tatar.ru/eng/guide/show/1721.

136 Press Release, Minister of Foreign Affairs Sergei Lavrov, Summary of Remarks at a Meeting with Representatives of Russian Nongovernmental Organizations (Feb. 18, 2010), available at http://www.mid.ru/brp_4.nsf /e78a48070f128a7b43256999005bcbb3/147e175da591fbb4c32576d4002fb81d?Open Document.

137 Minister of Foreign Affairs, Sergei Lavrov at the XIV World Russian People's Council, supra note 128. This effort also involves empowering the Organization of the Islamic Conference (OIC) and other similar bodies:

Russia welcomes the strengthening of the constructive role of the OIC in world affairs ... Russia firmly intends to continue its policy of expanding cooperation with the Islamic world in different fields, which has already become an important factor of shaping a polycentric international system based on the principles of justice, the equality of all states and solidarity in the face of common challenges.

Press Release, Minister of Foreign Affairs, Sergei Lavrov, Address at 36th Session of OIC's Council of Foreign Ministers (May 23, 2009), available at http:/ / www.mid.ru/Brp_4.nsf/arh/991F509BB79994F7C32575C1002B9F45?Open 
himself. Medvedev has stressed the need to boost cooperation between religions within the U.N. system, including the United Nations Educational, Scientific and Cultural Organization (UNESCO): "Consultations in this format should help to address important issues such as the settlement of interreligious conflicts, combating defamation of religions, and the preservation and protection of sacred places during armed conflicts." 138 Within this framework, Medvedev has expressly endorsed grafting Russia's already skewed and exclusionary domestic vision for religious dialogue ${ }^{139}$ onto the international level, boasting that:

Document. See also Press Release, President of Russia, Dmitry Medvedev Sent a Greeting to Participants of The Meeting of The 'Russia-Islamic World' Strategic Vision Group, (Oct. 28, 2008, 10:10 PM), available at http:/ /archive.kremlin.ru/eng/text/news/2008/10/208478.shtml.

The illusion of a unipolar world is receding before our very eyes. And forums like yours can make a significant contribution to the search for ways to improve the situation in the world and achieve a new level of global partnership. I am confident that active cooperation between Russia and the Islamic world will help build a more equitable system of international relations in which the use of force will definitively cease to act as a universal tool for resolving all problems that arise.

Id. The consistent manner in which religion is used to reinforce Russia's desire for a multipolar world is apparent in Russia's foreign policy statements at all levels of government. See Interview with Mintimer Shaimiev, President of Tatarstan, in Jeddah, Saudi Arabia (Nov. 5, 2008), available at http://shaimiev.tatar.ru /eng/pub/view/4781?highlight=Strategic\%20Vision\%20Group:\%20Russia\%20an $\mathrm{d} \% 20$ the\%20Islamic\%20World (Following the fourth Strategic Vision Group meeting, Shaimiev stated that Russia should "boost the activities of [OIC entities] . . . based on a multi-polar view of the world" and that "strategic cooperation with Russia is very important for the Muslim states, as Russia aims for a multi-polar world and does not entrench upon the values, traditions, uniqueness and sovereignty of the Muslim East's states").

138 Press Release, President of Russia, Dmitry Medvedev Met with DirectorGeneral of UNESCO Koichiro Matsuura and Members of The High Level Group for Interreligious Dialogue Under The Aegis of UNESCO Headed by Patriarch Kirill of Moscow and All Russia (Jul. 21, 2009), available at http://archive.kremlin.ru/eng/text/news/2009/07/219991.shtml. Medvedev reiterated his support for an interreligious dialogue within UNESCO during his address to the $64^{\text {th }}$ U.N. General Assembly: "we believe that establishing a highlevel group on interfaith dialogue under the Director-General of UNESCO is extremely valuable." U.N. GAOR, 64th Sess., 4th plen. mtg. at 19, U.N. Doc. A/64/PV.4 (Sept. 24, 2009). See infra section 3.2.5.3. (considering Russia's motivation for supporting an international ban on defamation of religion).

139 Blitt, One New President, supra note 2, at 1343 ("Although Medvedev acknowledged that the [Russian] Constitution provides for freedom of conscience and separation of religious associations from state, he conspicuously omitted 
Russia has its own place in the sun and unique experience of interreligious dialogue, experience which has accumulated over centuries. In general we believe that this is very advantageous; it has helped us create a great country . . . where the fundamental rights of religious denominations are respected, where civil peace and harmony reign. ${ }^{140}$

This distortion of Russia's actual track record on religious freedom, fundamental rights and tolerance is, not surprisingly, echoed by the ROC in its effort to preach the virtues of adopting Russia's discriminatory model on the global level. According to Archpriest Vsevolod Chaplin, Deputy Head of the Moscow Patriarchate's DECR, Russia's example of inter-religious harmony "is in demand in the world which increasingly understands that it is necessary to respect different civilizations with their religious or secular roots, their laws, rules, social models and political systems . ..."141 But others are less sanguine about using Russia as a model for religious coexistence and tolerance. For example, Walter Laquer flatly observes that "Appeals for a dialogue between [Islam and Orthodoxy in Russia] are mere eyewash; there is no such readiness to talk on either side."142 More generally, the U.S. Department of State's most recent report on religious freedom in Russia notes that "religious minorities, in particular Muslim followers of Turkish theologian Said Nursi's work, Jehovah's Witnesses, and Scientologists, faced bans on their religious literature and difficulties registering their legal entities" and observes that the government did not always respect constitutional

mention of Article 14's affirmation that the 'Russian Federation shall be a secular state ....'”).

140 Press Release, President Dmitry Medvedev, Opening Remarks at Meeting with Director-General of U.N. Educ., Scientific and Cultural Org. (UNESCO) Koichiro Matsuura and Members of The High Level Grp. for Interreligious Dialogue Under the Aegis of UNESCO's Director-General, (July 21, 2009), available at http://archive.kremlin.ru/eng/text/speeches/2009/07/21/1950_type84779 _219995.shtml.

141 A Russian Priest Visits Saudi Arabia for the First Time, supra note 134.

142 Walter Laqueur, Russia's Muslim Strategy, 6 MiddLE EAST PAPERS 1, 11 (Nov. 1, 2009), available at http://blogs.law.harvard.edu/mesh/files/2009/10 /russia_islam_laqueur.pdf. 
provisions upholding the equality of all religious groups and the separation of church and state. ${ }^{143}$

With some recent traction emerging at UNESCO, the ROC has plans to establish a secretariat in Paris to cooperate with and provide "religious expertise [for the] UNESCO agenda."144 This consultative group will be spearheaded by the ROC and include only "traditional religious communities." 145 In a letter to UNESCO Director General Irina Bokova, Patriarch Kirill underscored that UNESCO's goals can only be achieved "on condition of constructive interaction between UNESCO and traditional religious communities ...."146 Again, the Russian government's endorsement of this approach-and failure to speak out in any meaningful way to ensure representation of all faiths in this dialogue-ratifies the discriminatory domestic status quo and reinforces the failure to respect the obligations set forth in the 1993 constitution. ${ }^{147}$ And yet beyond UNESCO, the Russian government also intends "to reinvigorate" efforts to establish similar religious consultative councils "in the framework of . . the Council of Europe and the OSCE,"148 as well as in fora such as the U.N. Alliance of Civilizations. ${ }^{149}$

Although Lavrov's goal of combating manifestations of xenophobia is laudable, the actual direction and makeup of the envisioned council supported by the Russian government leaves much to be desired. In the first instance, it is incongruous to label the ROC an enemy of xenophobia when the Church itself has failed to meaningfully condemn hostility against Russian minorities, including gays, 150 migrants, 151 and adherents of other faiths. ${ }^{152}$ Second, it is evident from above that the intent underlying this consultative council is to legitimate on the international level the ROC's discriminatory domestic understanding of "interreligious" dialogue. In other words, before any "dialogue" can commence, minority and "nontraditional" faiths as well others, must be left by the wayside or accepted merely as token participants. ${ }^{153}$ For example, consider the ROC's decision to break off a fifty-year "dialogue" with the Evangelical Church in Germany (ECG)

143 See U.S. Dep't of State, Bureau of Democracy, Human Rights, and Labor, International Religious Freedom Report 2010, Russia (Nov. 17, 2010), available at http://www.state.gov/g/drl/rls/irf/2010/148977.htm (reporting on the state of religious freedom in Russia). 
144 Russian Church to Set Up Consultative Group on Interreligious Dialogue at
UNESCO, INTERFAX 2009), http://www.interfax-
religion.com/?act=dujour\&div=202.
145 Russian Patriarch Urges UNESCO to Cooperate with Religious Communities,
INTERFAX (Oct. 20, 2009, 10:16 AM), http:// www.interfax-religion.com
/?act=news\&div=6567. This limitation is also troubling from the perspective that
UNESCO Director General Koichiro Matsuura reportedly left his meeting with the
ROC "completely satisfied with the outcome." See also Russian Church to Set Up
Consultative Group on Interreligious Dialogue at UNESCO, supra note 144 (discussing
the plans of the Russian Orthodox Church to form a consultative group).
146 Russian Patriarch Urges UNESCO to Cooperate with Religious Communities, supra note 145 .

147 It also serves as further evidence that the preambular distinction between "traditional" and so-called "non-traditional" religions established under the 1997 Law on Freedom of Conscience has achieved legal recognition and officially legitimates discriminatory treatment between these two sub-classes. See Blitt, One New President, supra note 2, at 1346-47; Arina Lekhel, Leveling the Playing Field for Religious "Liberty" in Russia: A Critical Analysis of the 1997 Law "On Freedom of Conscience and Religious Associations," 32 VAND. J. TRANSNAT'L L. 167 (1999) (analyzing the effects of 1997 law "On Freedom of Conscience and Religious Associations" which curtailed the legal rights of certain religious groups); O Svobode Sovesti i o Religioznikh Objedinenijah [On the Freedom of Conscience and Religious Associations], art. 4(4), SOBRANIE ZAKONODATEL'STVA ROSSIISKOI FEDERATSII [SZ RF] [Russian Federation Collection of Legislation] 1997, No. 39, Item 4465 (Federal Law No. 125-FZ).

148 Sergei Lavrov, Minister of Foreign Affairs Speech at the XIV World Russian People's Council, supra note 128.

149 See Activities of Non-governmental Organizations and Cooperation with the Alliance of Civilization are Discussed at the Russian Ministry of Foreign Affairs, DEP'T FOR EXTERNAL CHURCH REL. OF THE RUSSIAN ORTHODOX CHURCH (Nov. 27, 2009), http://www.mospat.ru/en/2009/11/27/news9232/ (summarizing, briefly, a November 2009 meeting of the Russian Ministry of Foreign Affairs and the Russian Orthodox Church regarding cooperation with the U.N. Alliance of Civilizations).

150 See Russian Nationalists Attack Gays, Right Said Fred, and a German Politician, SPIEGEL ONLINE INTERNATIONAL (May 28, 2007), http://www.spiegel.de /international/world/0,1518,485262,00.html (reporting on a violent Moscow counter-protest against gay rights in which fundamentalist members of the Russian Orthodox Church participated); see also Phoebe A. Greenwood, Crucible of hate, GUARDIAN UK (May 31, 2007), http://www.guardian.co.uk/world/2007/jun /01/gayrights.poland (reporting on opposition to gay rights in Eastern Europe and noting the Russian Orthodox Church's "condemnatory" stance toward homosexuality); Paul LeGendre, Minorities Under Siege: Hate Crimes and Intolerance in the Russian Federation, HUMAN RIGHTS FIRST (June 26, 2006), available at http://www.humanrightsfirst.org/wp-content/uploads/pdf/06623-discrimMinorities-Under-Siege-Russia-web.pdf (discussing the problem of racist and xenophobic violence in Russia and proposing solutions).

151 See James W. Warhola, Religion and Politics Under the Putin Administration: Accommodation and Confrontation within "Managed Pluralism," $49 \mathrm{~J}$. CHURCH \& ST. 
following the election of Bishop Margot Kaessmann as head of the Church Council.154 Despite her short-lived tenure of four months-she resigned several days after police arrested her for running a red light while intoxicated ${ }^{155}$-Metropolitan Hilarion, reiterating the Patriarch's view, as stated:

75, 77-78 (2007) (considering the Putin administration's disposition toward Russia's Orthodox majority and its Muslim community).

152 See, e.g., Zoe Knox, Russian Orthodoxy, Russian Nationalism, and Patriarch Aleksii II, 33 NATIONALITIES PAPERS 533, 535 (2005) (discussing anti-Semitic reactions of Orthodox Church members to Patriarch Alexy II's November 1991 speech to rabbis in New York City). Knox concludes:

Whilst it is true that condemning extremist tendencies [within the ROC] would result in a backlash against the Moscow Patriarchate, this would be no worse than the current rupture between liberal and conservative clergy and the subsequent controversy would be no greater than the polemics on [Patriarchate Alexy's] political tendencies.

Id. at 542 .

153 Sergei Lavrov has expressed his conviction that only the "main world religions" can restore the "common moral denominator" underpinning the concept of rights and that "harmonious development of all humanity is impossible without this." Sergei Lavrov, Minister of Foreign Affairs of the Russian Federation, Address to XV Assembly of the Council on Foreign and Defense Policy (Mar. 17, 2007), available at http://www.norway.mid.ru /old/news_fp/news_fp_06_eng.html.

154 According to Metropolitan Hilarion, "[s]o far we have had meetings between Heads of our Churches, that is to say, between the Patriarch and the chairman of the Council of the Evangelical Church in Germany. Now such a meeting has become impossible . . . a meeting between Patriarch Kirill and Ms Kaessmann would look like the recognition of female priesthood by our Church." See Archbishop Hilarion's [sic] Answers Questions from Der Spiegel, DEP'T FOR EXTERnAl Church Rel. OF THE Russian ORTHOdOX CHURCH (Dec. 14, 2009), http://www.mospat.ru/en/2009/12/14/news10180 (containing the interview that was published in DER SPIEGEL issue No. 51, 2009). Metropolitan Hilarion's December 2009 letter to the ECG assessing the status of relations between the two churches is available at Archbishop Hilarion's letter to Chairperson of the Council of the Evangelical Church in Germany Dr. Margot Kaessmann and Head of the Department for Ecumenical Relations and Ministries Abroad Bishop Martin Schindehutte, INTERFAX (Dec. 17, 2009), http:/ / www.interfax-religion.com/?act=documents\&div=156.

155 See Germany Reacts with Understanding to Bishop's Resignation, DEUTSCHE WeLLE (Feb. 25, 2010), http://www.dw-world.de/dw/article/0,,5283198,00.html (reporting on the German peoples' reactions to Bishop Margot Kaessmann's resignation after being convicted of drunk driving); see also German Church Leader Kaessman Admits Drink-Driving, BBC News (Feb. 23, 2010), http://news.bbc.co.uk/2/hi/8530736.stm (reporting that Bishop Margot Kaessmann admitted to drunk driving). 
[T] he election of Ms. Kaessmann was only the tip of an iceberg of a sort. ... [W] disagree in principle with the liberalization in theology, church order and morality which takes place in many Protestant communities including the ECG. We should be frank and ask: Is there any sense in conducting a dialogue if it does not bring us closer together? ${ }^{156}$

At the very least, therefore, continued advocacy of this type of international "interreligious" council on the part of the Russian MOFA represents an attempt to reinforce the discrimination that persists within Russia's domestic context and further undermine existing international human rights norms governing freedom of religion or belief, which are buttressed by the principles of nondiscrimination and equality. Equally alarming, however, an examination of the priority issues to be advocated by such a council signals a larger effort to upend traditional international human rights norms by, inter alia, seeking to promote a prohibition on "defamation" of religion ${ }^{157}$ and a retrograde effort to contextualize other existing rights protections in light of so-called "traditional" and "religious" values. 158

156 Metropolitan Hilarion of Volokolamsk's Interview to Interfax-Religion Portal, DeP'T FOR EXTERNAL Rel. OF THE Russian ORTHOdOX CHURCH (Mar. 4, 2010), http://www.mospat.ru/en/2010/03/04/news14104/.

157 See, e.g., Press Release, President of Russia, Dmitry Medvedev Met with Director-General of UNESCO Koichiro Matsuura and Members of The High Level Group for Interreligious Dialogue Under The Aegis of UNESCO Headed by Patriarch Kirill of Moscow and All Russia , supra note 138; see infra sections 3.2.5.3, 4 (mentioning Medvedev reiterated his support for an interreligious dialogue within UNESCO). For more on the challenge presented by the effort to enshrine a ban on defamation of religion, see Robert C. Blitt, The Bottom Up Journey of "Defamation of Religion" from Muslim States to the United Nations: A Case Study of the Migration of Anti-Constitutional Ideas, 56 STUD. IN LAW, POL. AND Soc'Y 121, 121-211 (2011) (discussing the defamation of religion "as a violation of international human rights law").

158 Human Rights Watch called the passage of a resolution on traditional values backed by Russia at the U.N. Human Rights Council "divisive and dangerous" and "a cause for concern." See UN Human Rights Council: "Traditional Values' Vote and Gaza Overshadow Progress, Human Rights Watch (Oct. 2, 2009), http://www.hrw.org/news/2009/10/05/un-human-rights-council-traditionalvalues-vote-and-gaza-overshadow-progress. One reason for concern over this resolution is that "women are often the subject of traditions, often linked to national, cultural or ethnic norms, which violate human rights and freedoms." UN Resolution on Traditional Values: What's at Stake for Women's Rights?, Ass'N FOR 


\subsubsection{Kirill at the U.N.}

In between lobbying the United Nations and its individual member states for the establishment of a consultative council on religions and sponsoring Russia's "spiritual" renewal in lockstep with the ROC, the Russian Foreign Ministry also managed to facilitate a speech by then Metropolitan Kirill to the U.N. Human Rights Council (HRC). In March 2008, the HRC held a discussion entitled "Intercultural Dialogue on Human Rights." The discussion was "[a]ctively supported by the Russian Federation and Russian Orthodox Church."159 Not to be outdone by his counterparts in New York, Ambassador Valery Loshchinin, Permanent Representative of the Russian Federation to the United Nations and other International Organizations in Geneva, made sure to promote the historic event in advance. 160

Metropolitan Kirill took his opportunity during the HRC plenary meeting to lament his belief that:

WOMEN's RigHTS IN DEV. (Oct. 5, 2009), http://www.awid.org/Library/UNResolution-on-Traditional-Values-What-s-at-Stake-for-Women-s-Rights.

According to the Japanese delegation, "the concept of "traditional values of humankind' [used in the resolution text] was of concern. The use of the term 'traditional values of humankind' without any qualification vis-à-vis international human rights law was unacceptable." Press Release, Human Rights Council Adopts Six Resolutions and One Decision On Discrimination Against Women and Freedom of Expression, Among Others (Oct. 2, 2009), http://www.unhchr.ch /huricane/huricane.nsf/0/6A69FF0F95283CE7C12576430046793B?opendocumen t. For additional context on the implications of "traditional" values, consider for example the government of Iran's recent effort to justify "paternalism and genderinequality under the guise of traditional values and cultural relativism." Letter By Women's Rights Activists To Members of the United Nation's Economic and Social Council, Unrepresented Nations AND Peoples Organization (Apr. 28, 2010), http://www.unpo.org/content/view/11047/89/. The letter was signed by seven women's rights organizations and more than 200 Iranian human rights activists. Id.

159 Press Release, Ministry of Foreign Affairs of the Russian Federation, Intercultural Dialogue on Human Rights Discussion at the 7th Session of the UN Human Rights Council (Mar. 21, 2008), http://www.mid.ru/Brp_4.nsf/arh /6602DE7542DB0D12C325741600550E05?OpenDocument.

160 See Metropolitan Kirill of Smolensk and Kaliningrad Will Address the 7th session of the UN Human Rights Council During the Panel on "Intercultural Dialogue on Human Rights" on March 18, PERMANENT Mission OF THE Russian FED'N (Mar. 14, 2008), http://www.geneva.mid.ru/press/e_2008_11.html (announcing the Patriarch of Moscow's then-upcoming speech to the U.N. Human Rights Council.) 
The human rights approach has been [] used to justify the outrage against and distortion of religious symbols and teachings. The same approach is used today to impose a certain course of introduction to various religions in schools instead of teaching the basics of their own religion .... In addition, there is a strong influence of extreme feministic views and homosexual attitudes to the formulation of rules, recommendations and programs in human rights advocacy, which are destructive for the institution of family and reproduction of population. ${ }^{161}$

Further on in his address, Kirill stressed the need for a relativistic approach to international human rights, one that ought to be:

implement[ed] [] taking into account the cultural distinctive features of a particular people. In some countries the population is more religious than in others and religion therefore can and must play a more prominent role in the formation and implementation of human rights. Besides, every nation has its own historical experience, cultural traditions and its own system of meanings. These realities should not be ignored in building a national human rights system. ${ }^{162}$

In closing, Kirill called for fundamental moral norms of "major world religions" to inform the development of international law as a means of avoiding "alienation and opposition of a considerable part of humanity to the [existing] global processes."163 He also reiterated the Russian government's call for establishing a consultative council on religion. ${ }^{164}$ Shortly after the speech, the Conference of Non-Governmental Organizations in Consultative

161 The Address of Metropolitan Kirill of Smolensk and Kaliningrad, Chairman of the Moscow Patriarchate DECR on the Panel Discussion on Human Rights and Intercultural Dialogue at the 7th session of UN Human Rights Council, INTERFAX (Mar. 22, 2008), http://www.interfax-religion.com/?act=documents\&div=121.

$162 \mathrm{Id}$.

163 Id.

164 See Intercultural Dialogue on Human Rights Discussion at the 7th Session of the UN Human Rights Council, supra note 159 ("In practical terms, as Metropolitan Kirill stressed, such discussion [about interculture and interfaith dialogue] may be realized by means of the creation of a special UN Council of Religions."). 
Relationship with the United Nations (CONGO) Sub-committee on Freedom of Religion and Belief decried the fact that "no government had criticized Metropolitan Kirill's dismissive remarks about multi-cultural education and also about the rights of women."165

What is most remarkable about Kirill's sermonizing against sixty years of human rights development (to say nothing of his ignorance concerning the diversity of views included in the drafting of the Universal Declaration of Human Rights ${ }^{166}$ ), is the fact that the Russian government went out of its way to publicize the event, in essence elevating Kirill to the status of one of its official agents. A survey of 150 "Info-Digests" published by Russia's Permanent Mission between 2007 and 2010 reveals that Kirill's speech was the only non-governmental event ever reported by that office. ${ }^{167}$ In other words, news of the Metropolitan's speech was promoted in an official government publication otherwise reserved for disseminating the official statements, speeches, interviews, transcripts, and press briefings of prominent governmental figures such as the president and foreign minister.

Further augmenting the impression that the Metropolitan's words carried the weight of state sanction is the fact that Russia's delegation in Geneva, in addition to promoting the address through its office, took the time to photocopy Kirill's speech onto the Permanent Mission's official government letterhead for

165 CONGO Committee on Sub-committee on Freedom of Religion and Belief, Draft Minutes of Meeting of 22 April 2008, http://www.ngocongo.org/index.php ?what $=$ committees\&id $=27 \&$ start $=4$.

166 For example, The Arab Human Development Report 2004 recalls "the extent of the Arab contribution, whether on the part of the Arab states that actively and effectively participated in debates on the substantive elements of human rights standards, or in the persons of distinguished Arab experts who helped shape international human rights law." U.N. DEV. PROGRAMME, THE ARAB Human DeV. ReP. 2004: TOWARdS FrEEdOM IN THE ARAB WorLd 75. See also Pillay, infra note 324 (stating that the Declaration of Human Rights was drafted by and based on a project that drew from cultures and traditions across the world).

167 The Author conducted the survey based on the list of "Info-Digests" available from Russia's Permanent Mission website. The period covered runs from March 15, 2007, to May 18, 2010. See Digests, PERMAnEnt Mission OF THE RUSSIAN FED'N, http://www.geneva.mid.ru/digests/digests.html (containing 'info digests' created by the Russian Federation from 2007-2010). 
circulation in both paper and electronic format. 168 Likewise, the Information and Press Department of Russia's Foreign Ministry distributed Kirill's speech in its entirety and supplemented it with a separate press release excerpting highlights from the Metropolitan's address. ${ }^{169}$ This would tend to reinforce the view that Russia's MOFA had advanced access to the speech and may have signed off on its content beforehand. ${ }^{170}$

Ultimately, Kirill's MOFA-backed "dialogue" with the U.N. HRC signaled only the opening salvo in an ongoing effort by Russia at the U.N. to label existing international human rights norms "western" and press for a reinterpretation of these norms through the lens of "traditional values". ${ }^{171}$ This effort continues to

168 A copy of Kirill's address on the Permanent Mission's letterhead is on file with the Author.

169 See Vystuplenie predsedatlia Otdela vneshnih tsrkovnyh sviazei Moskovskogo partiarha Mitropolita Smolenskogo I Kalingradskogo Kirilla na panel`noi diskusii 7-I sessi Soveta OON po pravam cheloveka "Mezhkul turnyi dialog po pravam chelovea," Zheneva, 18 marta 2008 goda [Speech by the Chairman of the Department for External Church Relations of Moscow, Patriarchate Metropolitan Kirill of Smolensk and Kaliningrad, on the Panel Discussion, $7^{\text {th }}$ Session of the UN Human Rights Council, "Intercultural Dialogue on Human Rights"] (Mar. 20, 2008), http:/ / www.mid.ru/brp_4.nsf/0/1F665EF009509920C3257412003CB456; vystuplenii mitropoloita Kirilla na 7-I sessi Soveta OON po pravam cheloveka [Address of Metropolitan Kirill at the $7^{\text {th }}$ Session of the UN Human Rights Council] (Mar. 20, 2008),

http://www.mid.ru/brp_4.nsf/0/18AE82A7BB22438EC32574120032CB68.

170 The press release issued by Russia's Permanent Mission four days in advance of Kirill's address underscores this close collaboration. It states, inter alia:

The statement of Metropolitan Kirill at the session of the Human Rights Council will make an interim review of the activities of the Russian Orthodox Church in the field of human rights. The Chairman of the Department for External Church Relations of the Moscow Patriarchate will bring arguments in favor of the importance of perceiving human rights with due respect to traditional morality and Christian anthropology and will draw attention to the dangers resulting from liberty without morals.

Metropolitan Kirill of Smolensk and Kaliningrad Will Address the 7th session of the UN Human Rights Council During the Panel on "Intercultural Dialogue on Human Rights" on March 18, supra note 160. Representatives of the ROC continue to enjoy meetings with Ambassador Loshchinin, discussing, among other things, "the meaning of traditional values" and the "spiritual component in international relations." Archbishop Hilarion visits Russian Diplomatic Mission in Geneva, Russian ORTHODOX CHURCH (Dec. 15, 2009), http://www.mospat.ru/en/2009 /12/15/news10249/.

171 The UNHRC resolution on traditional values is discussed infra Section 4.1. 
be promoted at the highest echelons of the Russian government with Foreign Minister Lavrov's own speeches reiterating the themes initially highlighted by Kirill:

Against the background of the global crisis the invalidity of attempts at a new ideologization of international relations, proceeding from a false premise that there is only onewestern-"genuine" civilization stands out even more visibly. Under these conditions we are witnessing even more clearly the growing role of the religious factor in international affairs, and the demand for efforts predicated on common moral regularities in establishing and fostering a broad interconfessional dialogue and strengthening intercivilizational harmony.

We are gratified by the active participation of the Russian Orthodox Church in these efforts. Its voice in defense of spirituality, peace and harmony and of truth and justice is clearly heard not only in Russia, but also everywhere in the world. ${ }^{172}$

\subsubsection{Building the ROC's Reach: Unification \& Church Construction Abroad}

\subsubsection{ROC/ROCOR Merger Overseen by Putin}

Another way the Russian government has put the rhetoric of spiritual values into practice is manifested in its intimate involvement in enlarging the ROC's physical and geographic reach abroad. In the first instance, President Putin played an instrumental role in ending the eighty-year schism between the ROC and the long-estranged Russian Orthodox Church Outside Russia (ROCOR). ${ }^{173}$ In 2007, representatives of the two churches signed an Act of Canonical Communion at Moscow's Christ the

172 Sergei Lavrov, Minister of Foreign Aff. of the Russian Fed'n, Remarks at the Foreign Ministry's Reception on the Occasion of Orthodox Easter (Apr. 22, 2009), available at http://www.mid.ru/brp_4.nsf/0 /3E6860616E4FA4F6C32575A2001CAFAC.

173 The split occurred in the 1920s when members of the Russian Orthodox faith severed ties with the Moscow Patriarchate in response to Patriarch Sergei's decision to swear loyalty to the communist government. See infra note 179 (describing the acrimony of the split). 
Savior Cathedral, effectively reuniting two major branches of Russian orthodoxy. At the signing ceremony, Putin remarked, "We understand well, and value, the power of pastoral words which unite the people of Russia. That is why restoring the unity of the church serves our common goals."174 Notably, the church merger brought the ROCOR's 400 parishes and 400,000 members worldwide within the fold of the Moscow Patriarchate. As the Wall Street Journal observed of the merger, "The [ROC] gains influence in the U.S., Western Europe and South America, where it had little presence. Mr. Putin also gains. The union blunts what has been one of his largest group of critics - Church Abroad clerics who regularly attacked his policies and human-rights record."175

Although the merger agreement preserves ROCOR's autonomy in organizational and economic matters, this assurance has proven inadequate for assuaging the concerns of many ROCOR clergy ${ }^{176}$ and parishioners who believe the Moscow Patriarchate has failed to adequately address its legacy of KGB infiltration ${ }^{177}$ or sufficiently insulate itself against current Russian government interference. This has resulted in a further rupture of the ROCOR, with those rejecting the merger arguing that they are preserving the true essence of Russian Orthodoxy. According to Rev. Victor Dobroff of New York City, an opponent of ROC-ROCOR unification: "in a very short time [the FSB will have] new spy nests

174 David Holley, Russian Orthodox Split is Mended, L.A. TIMES, May 18, 2007, http:/ /articles.latimes.com/2007/may/18/world/fg-orthodox18.

175 Suzanne Sataline, Cold War Lingers At Russian Church In New Jersey, WALL ST. J., July 18, 2007, at A1.

176 Estimates put the number at almost one third of ROCOR's clergy premerger. Id. (describing the sore point between the Church Abroad and Russian Orthodox Church in Moscow being the Russian church's links to the KGB, as shown in Soviet-era records); see also Alexander Osipovich, Pushing 2 Churches Closer to Each Other, THE Moscow TIMES, Feb. 12, 2008, http:/ / www.themoscowtimes.com/news/article/pushing-2-churches-closer-toeach-other/302273.html (noting the belief, among those in the Church Abroad who oppose mending the rift between the two Russian churches, that the ROC is still steeped in the Soviet-era tradition of appeasing the state).

177 See Oleg Kalugin, SPYMASTER: My ThIRTY-Two YeARS In INTELLigENCE AND ESPIONAGE AGAINST THE WEST 225-26 (2009) (discussing the KGB's "nearly total control" of the Russian Orthodox Church "both at home and abroad"); see also Blitt, One New President, supra note 2, at 713-14 (arguing that the KGB made the Russian Orthodox Church a virtual arm of the State and that the Church was totally under its control). 
all over the world, absolutely untouchable, working under the cover of the church."178 Another anti-union Orthodox Christian blogger describes the ongoing schism: "The cold hard truth is that Ecumenism and Sergianism ${ }^{179}$ are not gone: they are rather there in force. . . we are still dealing with the same old Soviet, ecumenist [Moscow Patriarchate] . . . the same old KGB agents with mitres: a communist hierarchy in a capitalist-but still sometimes totalitarian-modern Russia."180 This intense, often vitriolic, division in faith has also given rise to concrete disputes over ownership of churches and church real estate in the United States and elsewhere. ${ }^{181}$

178 Sataline, supra note 175 . Opponents of the merger commonly express the fear that Russian spies will manipulate the Church. See Holley, supra note 174 (noting that reunification has been controversial with some members of the Church Abroad who believe that the Moscow church has not addressed its infiltration by the KGB during the Soviet era); Osipovich, supra note 176 (describing the Church Abroad's opposition to the Moscow Patriarchate's relationship with the state).

179 According to an article in one anti-union Orthodox church newsletter:

But Christ never taught that when persecuted, to join with the persecutors to save our lives or to save the Church from annihilation. Such behavior was always condemned categorically and firmly by the Church as a denial of Christ. Such conduct can be understood and sympathized with, but it cannot possibly be justified or even extolled as being wise.

Here you have it-Sergianism not in words, but precisely, in deeds. In conclusion, I repeat the basic, perhaps unspoken idea of Sergianism: "when the Church is threatened by the danger of annihilation, it is permissible and acceptable to submit to any compromise with falsehood, even to the point of joining with the persecutors for the sake of preserving the Church and saving it from annihilation."

Nikita Grigoriev, On Sergianism, 1 SOWER 1, 1 (2010), http:/ / news.ruschurchabroad.org/storage/sower/TheSower-Vol01-Issue02E.pdf (emphasis omitted).

180 Joseph Suaiden, Everyone on the Lifeboats! A Letter to a Blogger, NOTES FROM THE UNDERGROUND (Apr. 13, 2010), http://news-nftu.blogspot.com/2009/04 / everyone-on-lifeboats-letter-to-blogger.html.

181 See, e.g., Jeffrey Gold, NJ judge: Diocese has Rights at Parish, USA TODAY, Sept. 8, 2007, http://www.usatoday.com/news/nation/2007-09-08 2258611882_x.htm (discussing ownership issues regarding the Sviato Pokrovskiy Russian Orthodox Church in Buena Vista, NJ); see also infra Section 4. 
While the fears of some anti-union Orthodox Christians may appear paranoid, 182 the fact that the ROC and Russian government collaborate closely is undeniable. Foreign Minister Lavrov described the signing of the Act of Canonical Communion as heralding "a new stage in our efforts to consolidate the Russian World" and has explained that "Russian diplomacy has consistently been for the unity of the Orthodox World" as a means of ensuring stability and a "just world order." 183 According to one journalist, the ROC-ROCOR merger sealed a "four-year long effort by Putin . . . to have the Moscow Patriarchate take over its rival American-based cousin and launch a new globalized Church as his state's main ideological arm and a vital foreign policy instrument." 184 Indeed, part of the drive toward reunification was fueled by the rationale that, if Russia were to successfully restore its lost superpower status, having a "superchurch" to bolster its ambition would be advantageous. ${ }^{185}$

The Moscow Patriarchate's unification with the ROCOR represents one piece of this puzzle. In a speech before some of the ROC's senior clergy, Medvedev welcomed the Church's growing significance as a force for securing Russian interests abroad and pointed to the ROC-ROCOR merger as the first step in consolidating Russia's "near abroad":

182 For example, Metropolitan Agafangel, a ROCOR bishop suspended for his rejection of the ROC-ROCOR merger, has claimed Russian agents are out to assassinate him for establishing a breakaway church. See Metropolitan Agafangel's, Nashe budushchee. Stranitsa 51, LiveJournal (Mar. 27, 2010), http://agafa-angel.livejournal.com/22269.html (stating that he was under surveillance by a group of "youngsters"); see also Joseph Suaiden, ROCOR-A Metropolitan Agafangel's Life Possibly in Danger, NOTES FROM THE UNDERGROUND (Mar. 27, 2010), http://news-nftu.blogspot.com/2010/03/rocor-metropolitanagafangels-life.html (noting, in his blog, that Metropolitan Agafangel announces that if he were ever to be "accidentally" killed, Patriarch Kirill is likely responsible).

183 Diplomacy Needs a Moral Foundation, supra note 45. Lavrov reiterates a similar position during his 2009 Orthodox Easter remarks. See Lavrov, supra note 172.

184 Yuri Zarakhovich, Putin's Reunited Russian Church, TIME, May 17, 2007, http://www.time.com/time/world/article/0,8599,1622544,00.html.

185 Payne, supra note 55, at 716 (quoting from Mikhail Pozdnyayev, The Strength and Weakness of Orthodoxy - Patriarch Aleksy II Confesses to the Church Abroad, 55 CURRENT Digest OF THE POst-SOVIET PRESS 19, 19 (2004)). 
We support the Church's efforts to strengthen the fraternal ties between Russia and its close neighbours. We are separated by national borders but we share a common past and common historic destiny .... [The reunification of the ROC and ROCOR] gave decisive impetus to consolidating the Russian world, making our ties with our compatriots all around the globe stronger than ever. ${ }^{186}$

\subsubsection{Laying Cornerstones for New Churches and Reclaiming Church Property Outside Russia}

In Medvedev's view, part of strengthening ties with compatriots abroad means ensuring a local foothold for ROC churches and clergy. Accordingly, the Russian government has been a strong proponent of efforts to build new Orthodox churches and pursue ownership claims against property currently maintained or controlled by Russian Orthodox communities that have either grown apart from the Moscow Patriarchate or are actively affiliated with the Constantinople Patriarchate (also referred to as the Ecumenical Patriarchate). ${ }^{187}$

New Orthodox churches are being built across the globe, situated in far-flung and often strategic locales such as Africa, ${ }^{188}$

186 Dmitry Medvedev, President of Russia, Speech at a Reception Given by the President of Russia in Honour of Senior Clergy Who Took Part in the Russian Orthodox Church Local Council (Feb. 2, 2009), available at http://archive.kremlin.ru/eng /speeches/2009/02/02/1738_type84779type127286_212375.shtml.

187 The historical divide between the "second" and "third" Rome is outside the scope of this article. For background, see Alicja Curanovic, The Attitude of the Moscow Patriarchate towards Other Orthodox Churches, 35 RELIGION, STATE \& SOC'Y 301, 301-18 (2007) (discussing the history of how the Third Council of Constantinople, which founded the Patriarchate of Constantinople, ordered the Orthodox churches and placed the Ecumenical Patriarchate in first position and the Moscow Patriarchate in fifth, which still remains a point of contention within the Universal Orthodox Church); see also Archpriest Vsevolod Chaplin wants Russia to become "Byzantium without its faults," INTERFAX (Feb. 29, 2008), http:/ / www.interfax-religion.com/?act=news\&div=4345 (stating Chaplin's belief that Byzantium "has reincarnated in Russia").

188 See Patriarch Kirill intends to open Russian parishes and build churches in Africa, INTERFAX (Apr. 12, 2010), http://www.interfax-religion.com $/$ ?act=news\&div $=7150$ (discussing the intention of the ROC to expand generally and specifically looking at its plans to build Russian churches in Africa). 
Argentina,189 China,190 Tokyo, Havana,191 Thailand,192 Madrid,193 and Abu Dhabi. According to Patriarch Kirill: "our parishes [in other countries] fulfill a cultural mission. They are an important link between their Motherland and the people living far away from their native country." 194 But Kirill has also opined that new churches operate as "another bridge to unite" Russia with other nations. ${ }^{195}$ From the Patriarch's statements, the construction of new churches signals more is at stake than the provision of spiritual services to an Orthodox Russian flock now living in a global village. As journalist Geraldine Fagin observed, "[o]ne of the very few things the Soviet government ever encouraged the Russian Orthodox Church to do was promote national interests abroad."196 And this is precisely what the new Orthodox churches

189 See A new Russian church to be constructed in Argentina, INTERFAx (Nov. 7, 2008), http:/ / www.interfax-religion.com/ ?act=news\&div=5348 (discussing plans to construct a new Russian church in Argentina).

190 See An Orthodox church consecrated in the territory of Russian embassy in Beijing, DEP'T FOR EXTERNAL CHURCH REL. OF THE RUSSIAN ORTHODOX CHURCH (Oct. 13, 2009), http://www.mospat.ru/en/2009/10/13/news6465/ (discussing the consecration of a Russian Orthodox church in the territory of the Russian embassy in Beijing, China).

191 See Orthodox Church Spreads Kremlin's Word, INTELLIGENCE ONLINE (March 11, 2010), http://www.intelligenceonline.com/government-intelligence /2010/03/11/orthodox-church-spreads-kremlin-s-word,82105027-ART-

ignorevalide (discussing how the Kremlin is using ROC as an arm to further its foreign policy objectives, with specific detail on how the ROC has expanded globally to places as far and wide as Tokyo and Havana).

192 The ROC consecrated its second church in Thailand, located in the resort town of Pattaya, in December 2009. See Archbishop Hilarion Consecrates New Russian Church in Thailand, RIA NovOsTI (Dec. 20, 2009), http://en.beta.rian.ru /Religion/20091220/157306114.html (discussing the consecration of a new Russian church in Thailand).

193 See Russian Orthodox Church to be Given a Plot of Land for Building a Church in Madrid, DEP'T FOR EXTERNAl CHURCH REL. OF THE RUSSIAN ORTHODOX CHURCH (June 24, 2010), http://www.mospat.ru/en/2010/06/24/news20874/ (discussing ROC's plans to build a new church in Madrid, Spain). at 14

194 Church Diplomacy Is not Just a Matter of Inter-Church Relations, supra note 5,

195 Patriarch Kirill Believes New Russian Parishes likely to appear in Latin America, INTERFAX (Sept. 21, 2009), http://www.interfax-religion.com/?act $=$ news\&div $=6460$ (discussing how an increasing number of people of Russian culture visit or move to Latin America).

196 Geraldine Fagan, Russia's Ambitious New Patriarch, OPEn DemOCRAcy (Feb. 12, 2009), http://www.opendemocracy.net/article/email/russia-s-ambitiousnew-patriarch. 
are poised to do. In the words of one high-level Russian government official, new church construction is "a very important event even for Russia's secular power."197

The ROC does not undertake the impressive task of building new churches singlehandedly. The Russian MOFA is virtually omnipresent in the Church's construction efforts abroad. Sergei Lavrov has stated that the MOFA and its diplomatic missions abroad "comprehensively help ... the expansion of the presence of the Russian Orthodox Church."198 What this means more specifically, Lavrov explains at length:

The Foreign Ministry of Russia actively helps communities of the Russian Diaspora, even to meet their spiritual needs. And, whenever our compatriots say they want to build a church, we begin working on the matter in close cooperation with the leaders of the Russian Orthodox Church and the host country concerned. This is also so when it comes to transferring the property rights to temples that are monuments of Russian culture and faith back to Russia. We proceed from the assumption that the establishment of spiritual life is one of the key factors in the well-being of the Russian Diaspora. ${ }^{199}$

The most prominent recent example of this commitment came in February 2010 when the Russian government "went to extraordinary lengths" 200 to emerge as the highest bidder for a twoacre plot of land abutting the Seine River in downtown Paris, "à

197 Putin's visit to UAE to consolidate RF's positions in Arab world, ORG. OF ASIAPACific News AgenCIES, Sept. 4, 2007.

198 Press Release, Ministry of Foreign Affairs of the Russian Federation, Russian Minister of Foreign Affairs Sergei Lavrov Interview with RIA Novosti on Russian Relations with the Countries of Latin America and the Caribbean Basin (Nov. 17, 2008), http://www.mid.ru/bdomp/brp_4.nsf /e78a48070f128a7b43256999005bcbb3/40dff6a7982643e5c3257523003f9f19!OpenD ocument. The interview also underscores the secular importance and relevancy of Latin America for Russian foreign relations. Id.

199 Diplomacy Needs a Moral Foundation, supra note 45.

200 See Matthew Campbell, Onion Domes to Rise in Paris, The Sunday Times, June 6, 2010, available at FACTIVA, Doc. No. ST00000020100606e666000fs. (reporting that Russia has secured permission to build an orthodox church next to the Eiffel Tower). Among other steps, it "employed a French lobbying firm to get across the message: the Kremlin would consider a sale to anyone else an 'unfriendly act.'” Id. 
deux pas de la tour Eiffel."201 According to Russian Presidential Administration press secretary Viktor Khrekov, the property would be used to construct a new "Russian spiritual and cultural center." 202 However, despite President Medvedev's office publicly pitching the project as a generic "spiritual and cultural center," all other indicators-including a 2007 meeting between French President Nicolas Sarkozy and then-Patriarch Alexy II where the initial idea for constructing a new Orthodox Church in Paris was first broached ${ }^{203}$ - point to the high-profile property as being earmarked for exclusive use as a Russian Orthodox Church ${ }^{204}$ and "a seminary for educating priests." 205 Indeed, the Russian government's international architectural competition that closed in October 2010 sought out the "best design" for a "Russian Orthodox Religious and Cultural Center ... intended as a place for meetings, cultural events[,] and spiritual nourishment for the Russian community and for introducing Parisians to the Russian Orthodox culture." 206 The project promises to be the "first Russian Orthodox

201 See Vincent Jauvert, L'affaire de la Cathédrale du Kremlin à Paris [The case of the Kremlin Cathedral in Paris], Nouvel ObSERvateur (May 28, 2010), http:/ / globe.blogs.nouvelobs.com/archive/2010/05/28/comment-le-kremlin-aobtenu-sa-cathedrale-a-paris.html (reporting on the sale of a plot alongside the Eiffel Tower to the Kremlin). Russia's bid bested two other rivals, Canada and oilrich Saudi Arabia. Irina Filatova, Kremlin Acquires Plot Alongside Eiffel Tower, THE Moscow TIMES, Feb. 9, 2010.

202 Russia Wins Contest for Land in Paris to Build Spiritual Center There, INTERFAX (Feb. 8, 2010), http://www.interfax-religion.com/?act=news\&div=6907 (reporting that Russia placed the winning bid). See also Building of Russian Spiritual Center in Paris to start in 2012, INTERFAX (Feb. 11, 2010), http:/ / www.interfax-religion.com/?act=news\&div=6923 (describing the architect selection process for the planned Russian Spiritual Center in Paris).

203 See Jauvert, supra note 201 (detailing Russia's efforts to secure real estate for a cathedral in France).

204 See A Russian Orthodox Church to Be Built in Downtown Paris, DEP'T FOR EXternal Church Rel. OF THE Russian Orthodox CHurch (Feb. 9, 2010), http://www.mospat.ru/en/2010/02/09/news12868/ (reaffirming Russia's plan to build an Orthodox church on the site).

205 See Putin Thanks France for Decision to Build Russian Spiritual Center, ITARTASS WORLD SERVICE, June 11, 2010, available at Factiva, Doc. No. TASS000020100611e66b001e3 ("We are deeply grateful to the president and the government for this decision. This will be not only a reminder, but also an additional spiritual bridge, which is connecting the two nations." (quoting Russian Prime Minister Vladimir Putin)).

206 See International Contest for Best Design of Russian Orthodox Religious and Cultural Center Announced in Paris, DeP'T FOR EXTERnAl CHURCH ReL. OF THE 
cathedral built in France since the days of the Romanovs" 207 and "the first Russian monument built in Paris since the Alexander III bridge in 1896." 208

Plainly, the Russian government's commitment to this decidedly pricey transaction confirms the fact that in its view, the term "spirituality" translates not into Buddhism or Islam or Judaism, but rather into Orthodoxy alone to the exclusion of all others. More immediately, the purchase-coming at the expense of an estimated ninety million dollars ${ }^{209}-$ demonstrates the government's disregard for the constitutional propriety of expending state funds abroad to promote a single privileged faith.210 It also begs the further question: precisely what government interest is advanced by building a landmark Russian Orthodox Church in a city where the majority of Russiansimmigrants from the Bolshevik revolution-already have a church $^{211}$ and, in any case, are affiliated with the Ecumenical Patriarchate and thus do not recognize the Moscow Patriarchate's jurisdiction?212 This conduct is even more curious when considered against the backdrop of hundreds of rural churches in

\footnotetext{
RUSSIAN ORTHODOX CHURCH (Oct. $1, \quad$ 2010), http://www.mospat.ru/en/2010/10/01/news27203/ (announcing that the design of the cathedral will be determined by contest).

207 Campbell, supra note 200.

208 See Henry Samuel, French Secret Service Fear Russian Cathedral a Spying Front, THE DAILY TElegRAPH, May 28, 2010 (“The French secret service has reportedly expressed alarm over plans for a Russian Orthodox cathedral in Paris, fearing it will be used by Moscow as a front for spies ...."). land).

209 See Jauvert, supra note 201 (recounting Russia's winning bid for the plot of

210 The government will hand the land over to the exclusive use of the Moscow Patriarchate free of charge. See Alexander Soldatov, Shchiroko shchagaet pravoslavnaia tserkov' [Wide Strides for the Orthodox Church], NovAYA GAZETA, Feb. 19, 2010, available at http://www.novayagazeta.ru/data/2010/018/04.html (questioning the prudence of using taxpayer money to promote Russian Orthodox culture abroad).

211 These Russians belong to St. Alexander Nevsky Cathedral on Rue Daru. See infra Section 3.1.5.3.

212 See Soldatov, supra note 210 (explaining that most Russian immigrants in Paris recognize the Ecumenical Patriarchate of Constantinople as opposed to the Patriarchate of Moscow).
} 
Russia lying in disrepair and hundreds of thousands of Orthodox parishioners in Russia living in poverty. ${ }^{213}$

The fact that the high-profile Paris real estate deal is motivated by a desire to entrench the ROC's position abroad as a manifestation of Russia's reinvigorated "secular" state power is undeniable. This becomes particularly evident when viewed against the backdrop of other similar, if smaller-scale, attempts to acquire property rights to churches abroad on behalf of the ROC. The Russian government's activism here demonstrates clear support in favor of consolidating all Orthodox communities abroad under the control of the Moscow Patriarchate 214 as part of an overarching effort to entrench the image of a unified and omnipresent Russian state. Activity on this front has resulted in numerous bilateral negotiations for the return of property - as well as several contentious court battles-across a variety of jurisdictions including the U.K., Israel, Italy, France, and the United States. For example, Italian authorities agreed to the transfer of an Orthodox church to Russia during a 2007 visit by then-President Putin. ${ }^{215}$ The Russian government subsequently passed control of the Bari church to the ROC, expressing the hope that it would become "a spiritual center for promoting Orthodoxy in Italy." 216 The transfer prompted Patriarch Kirill to applaud the government's "very important participation" in facilitating the transfer ${ }^{217}$ as a sign of the government's "historic continuity of care

213 See id. (" $[\mathrm{H}]$ undreds of rural churches in Russia continue to be destroyed, and hundreds of thousands of parishioners ROC [sic] live in poverty.").

214 See Bruce Crumley, Why Russia Wants Its Orthodox Churches Back, TIME, Jan. 24, 2010, http://www.time.com/time/world/article/0,8599,1956045,00.html (contending that Russia endeavors to unify the various Russian Orthodox congregations for political purposes).

215 See Italy Hands Bari Church Over to Russia, INTERFAX (Apr. 17, 2008), http://www.interfax-religion.com/ ?act=news\&div=4575 (reporting that the city council of Bari agreed to transfer ownership of a local church to the Russian government).

216 See Russian Presidential Aide Hopes Bari Church Will Be a Center for Promoting Orthodoxy in Italy, INTERFAX (Feb. 27, 2009), http://www.interfax-religion.com $/$ ?act=news\&div $=5747$ (reporting that the Russian leadership views the transfer of the church as "an historic event").

217 See Orthodox Pilgrim Center in Bari Transferred to Russian Orthodox Church, INTERFAX (Nov. 25, 2009), http://www.interfax-religion.com $/$ ?act=news\&div=6670 (explaining how the Russian government returned the Bari church to ROC control). 
[for the] spiritual basics of our people." 218 Vladimir Kozhin, the head of the Kremlin's Property Department, has remarked that the Bari transfer represents only "the beginning," and that the government will continue to actively pursue the return of "shrines that are abroad of our homeland," including "in the Kingdom of Jordan and in Israel." 219

Other attempts to claim Church property have been less straightforward. This may be in part because in the case of the Bari church, municipal authorities assumed responsibility for maintaining the property rather than leaving the task to a local Orthodox congregation. 220 While the case of the Sviato Pokrovskiy Russian Orthodox Church in Buena Vista, N.J., appears to reflect a dispute between those in favor and those against the ROCOR-ROC union, others indicate direct involvement on the part of the Russian state. For example, in 2006, the Russian government began taking steps to gain possession of the St. Nicholas Cathedral, an Orthodox church built in 1912 on the French Riviera with funds provided by Czar Nicholas II.221 For the nearly ninety years preceding the Russian government's intervention, the Russian Orthodox Cultural Association of Nice (ACOR), an organization with ties to the Ecumenical Patriarchate, maintained and operated the church. In early 2010, a French court of first instance ruled that the property belonged to Russia and should revert to its government.222 According to Vladimir Kozhin, the Russian

218 Patriarch Kirill Thankful to Russian, Italy Authorities for Transfer of Bari Church, INTERFAX (Mar. 2, 2009), http://www.interfax-religion.com / ?act=news\&div=5750 (reporting that Patriarch Kirill called Italy's decision to return the Bari church "a just act").

219 Orthodox Pilgrim Center in Bari Transferred to Russian Orthodox Church, supra note 217.

220 See id. ("Russian emigrants . . . passed all church buildings to the municipality of Bari in 1937, because they lacked the funds to maintain the church.").

221 See John Tagliabue, A Cathedral Resists the Label 'Property of Russia', N.Y. TIMES, Jan. 9, 2008, http://www.nytimes.com/2008/01/09/world /europe/09nice.html (reporting on an international dispute over the ownership of the Cathedral of St. Nicholas).

222 See French Court Hands Nice Cathedral to Russia, RADIO FrEE EUROPE RADIO LIBRARY, Jan. 20, 2010, http://origin.rferl.org/content/French_Court_Hands _Nice_Cathedral_To_Russia/1934955.html (recounting the legal battle over ownership of the cathedral, which ended in a victory for the Russian government). 
government would "do everything possible ... to have this church come back. But it is a very complicated and lengthy process, we must be ready for this. They're all quite complicated, lengthy things, a very complicated jurisprudence on property issues, especially when different countries are involved." 223 For its part, the Moscow Patriarchate has claimed that it is "not directly connected to [the St. Nicholas] cathedral, since services there are conducted by a community belonging to another jurisdiction, but we are happy that the French state has acknowledged Russia's right to own this church." 224 Although the Russian government reportedly offered to allow the congregation to maintain use of the church for its services, ${ }^{225}$ it appears to have taken steps to assume management of the church,226 potentially signaling the first step in severing the cathedral's longstanding linkage to the Ecumenical Patriarchate and handing the church over to the ROC.227 The direction of legal battle over the church seems to confirm this eventuality. A petition by ACOR to the Aix-en-Provence Court of Appeal failed to reverse the court of first instance's ruling. Following ACOR's refusal to vacant the church, Russia obtained a

223 Russia's Taking Ownership of Church in Nice to be Long Process-Official, INTERFAX (Jan. 25, 2010), http://www.interfax-religion.com/?act=news\&div $=6849$.

224 Sophia Kishkovsky, Court Says French Cathedral Belongs to Russia, NATIONAL CATHOLIC RePORTER (Jan. 26, 2010), http://ncronline.org/news/global /court-says-french-cathedral-belongs-russia.

225 See Metropolitan Hilarion of Volokolamsk's Interview to Interfax-Religion Portal, supra note 156 (indicating that the transfer of ownership would not impinge on the regular operations of the local congregation).

226 See La Russie Réclame [Russia Claims], CATHÉDRALE RUSSE DE NICE [RUSSIAN CATHEDRAL OF NICE], Apr. 5, 2010, http://cathedralerussenice.org/spip/spip.php ?article13 (describing a notice sent by Russia to the Nice church demanding management changes).

227 Given the religious purpose associated with this property, such a step would be in keeping with domestic developments in Russia related to a new law on religious property that will see the ROC become one of the largest property owners in Russia, behind only Gazprom, the Russian gas monopoly, and Russian Railways. Kremlin Plans to Hand Over Property to Religious Groups, RIA NOvOSTI (Feb. 24, 2009), http://en.rian.ru/russia/20090224/120276640.html. See also Orthodox Church May Become One Of Largest Proprietors In Russia, ITAR-TASs WORLD SERVICE, Jan. 3, 2009, available at http://www.acg.ru/english /orthodox_church_may_become_one_of_largest_proprietors_in_russia (reporting that a proposed bill drafted by the Economic Development Ministry would make the Orthodox Church one of the largest private landowners in Russia). 
subsequent court order in November 2011 (at the time this article went to press) which, while falling short of evicting ACOR, required the organization to surrender the church keys within one week or face a fine of 6,000 Euros per day.228

In another dispute originating in Biarritz, local supporters of the Moscow Patriarchate moved to have the local Orthodox Church-long affiliated with the Ecumenical Patriarchate $229-$ revert its allegiance to Moscow. In what one observer described as a "putsch," 230 the effort to vote in favor of unification with Moscow landed the parties in court. After two appeals, the Cour de cassation ordered that the proposed realignment could not proceed due to irregularities in the voting procedure. 231

A similarly contentious effort to bring the Diocese of Sourozh in the United Kingdom under control of the Moscow Patriarchate resulted in a very public break within the congregation and another court challenge. ${ }^{232}$ The dispute centered on concern

228 Rémy Doncarli, Église Russe de Nice: L'Association Doit Rendre les Clés [Russian Cathedral of Nice: The Association Must Return the Keys], NicE Matin, Nov. 1, 2011, http://www.nicematin.com/article/nice/e-glise-russe-de-nicelassociation-doit-rendre-les-cles. For earlier coverage of the legal battle, see $\mathrm{La}$ Russie Réclame, supra note 226 (noting that ACOR has appealed the decision transferring the Nice church to Russia); see also France: The Legal Battle Surrounding St Nicholas Cathedral in Nice, DeuTSCHE Welle (June 23, 2010), http://www.dwworld.de/dw/article/0,5717054,00.html (reporting on the Nice parishioners' pending appeal); Communique No 05-10 of the Council of the Archdiocese Meeting of 21 and 22 June 2010, ECUMENICAl PATRIARCHATE: DEANERY OF GR. BRIT. AND IR., http:/ / exarchate.org.uk/communiqu\%C3\%A9-n\%C2\%B0-05-10-councilarchdiocese-meeting-21-and-22-june-2010 (last visited Nov. 17, 2011) (elaborating on the timeline for the appeals process).

229 As Daniel Payne points out, many parishes outside Russia "left the ROC and came under the jurisdiction of the Patriarchate of Constantinople . . . placing their properties under the control of Constantinople." Payne, supra note 55, at 718.

230 Jauvert, supra note 201.

231 See Cour de cassation [Cass.] [Supreme Court for judicial Matters], 1e civ, Oct. 8, 2009, (unpublished), Association Culturelle Orthodoxe Russe De Biarritz v. Eglise Orthodoxe Russe et al., Appeal No. 08-16896 (Fr.), available at http:/ / www.legifrance.org/affichJuriJudi.do?oldAction=rechJuriJudi\&idTexte $=\mathrm{J}$ URITEXT000021141022\&fastReqId=1642911898\&fastPos=1\# (rejecting applicants' appeal by invalidating a resolution of a general meeting of AROC because the meeting did not follow the statutory rules without the need to consider whether the irregularity had an impact on the adoption of decisions).

232 See Dean v. Burne, [2009] EWHC (Ch) 1250 (Eng.), available at 2009 WL 1504469 (granting control of the Diocese of Sourozh to the Moscow Patriarchate). 
among some clergy and laity that the ROC was attempting to move the Diocese away from its more "liberalized" Orthodox practice that had evolved over time and given its separation from Moscow. Initially, the diocese's leader, Bishop Basil, unilaterally sought release from the Moscow Patriarchate to join the Ecumenical Patriarchate 233 due to "'elements in the Moscow Patriarchate that support those who have been seeking to undermine my authority in the Diocese and are interfering in my conduct of its affairs.'" 234 However, upon learning of the bishop's actions, the ROC retired Basil "'without the right to transfer to another jurisdiction" "and moved to appoint Archbishop Innokenty "as temporary acting administrator of the Diocese of Sourozh." 235 Ultimately, the court decided to vest ownership of the diocese's property and assets with the Moscow Patriarchate.

According to Protodeacon Peter Scorer, formerly of the Diocese of Sourozh, the Russian government sees Orthodox churches abroad as "something like the embassy churches before the [Russian] revolution. They are representations of Moscow abroad, and are controlled not by their local bishops, but by the DECR [Department of External Church Relations of the Moscow Patriarchate]." 236 This view is further affirmed in the context of government and church activities in Russia's "near abroad." According to Alicja Curanovic, the Russian government and ROC:

are interested in retaining dominance in the post-soviet area, and to achieve this goal they support each other .... Russian authorities perceive the ROC as an ally in looking after state interests and strengthening the country's position in the international arena, and therefore supports [sic] the ROC's transnational activity.237

233 See id. at *21, I $58-59$ ("Bishop Basil took the momentous decision to move from the jurisdiction of the Moscow Patriarchate to that of the Ecumenical Patriarchate .... On 24 April 2006 Bishop Basil wrote to the Patriarch of Moscow asking to be "released from the Patriarchate of Moscow.'").

234 Id. at *21, ๆ 59 .

235 Id. at **22-23, ๆ 65.

236 Payne, supra note 55, at 723.

237 Alicja Curanovic, The Attitude of the Moscow Patriarchate Towards Other Orthodox Churches, 35 ReLIGION, ST. \& SOC'y 301, 312 (2007). 
In light of this mutual interest, whereby church and state act in tandem abroad to repossess old churches and build new ones, these facilities ought to be viewed as more than houses of worship. Rather, they operate as concrete manifestations of Russia's attempt to exert greater geographic reach and political influence. The Russian government's active role in securing these properties on behalf of the ROC signals its endorsement of the use of churches to bolster Russia's profile as well as its willingness to avail itself of the Church as a potential lever of soft power in its pursuit of foreign policy objectives. This situation gives rise to several problems. First, by venturing beyond the borders of the Russian Federation and even the so-called "near abroad," the Moscow Patriarchate appears willing to contravene its own ecclesiastic rule of "canonical territory," which posits the principle of "one city one bishop-one Church." 238 As Justice Blackburne explained in Dean v. Burne:

The point, as I understand it, is that the Moscow Patriarchate had no right to exercise its jurisdiction over Orthodox Christians worshipping outside the borders of Russia (ie [sic] the territories historically regarded as within the jurisdiction of the Moscow Patriarchate) and that, given the schism between Orthodoxy and the Church in the West dating back to 1054, jurisdiction over Orthodox worshippers in Western Europe falls to the Ecumenical Patriarch as locum tenens of the Patriarch of Rome. ${ }^{239}$

Daniel Payne observes that the "establishment of multiple churches in a single territory goes against the ecclesiological basis of the Orthodox Church."240 However, this is precisely what the ROC is poised to do in places as diverse as France, Italy, the United Kingdom, and Latin America. Such a move positions the Moscow

238 See Bishop Hilarion of Vienna and Austria: "One city-one bishop-one Church". The Principle of Canonical Territory and the Appearance of "Parallel Hierarchies," EUROPAICA Bull. (Jan. 23, 2006), http://orthodoxeurope.org /page/14/84.aspx\#5 (discussing the principle of canonical territory of "one city one bishop-one church" and describing the emergence of parallel hierarchies in Christendom).

239 Dean v. Burne, [2009] EWHC (Ch) 1250, q 33 (Eng.), available at 2009 WL 1504469, at *12, ๆ 36.

240 Payne, supra note 55, at 725. 
Patriarchate in direct competition with other churches (either western or "westernized" Orthodox) for governance over the spiritual lives of the faithful.

Former Patriarch Alexy previously asserted that the ROC's "first priority [on the international level] is to preserve the unity of the Church and ensure the spiritual life of the extensive church diaspora living outside the canonical territory of the Russian Orthodox Church (ROC)." 241 The patriarch's favored approach positioning the ROC to go wherever Russians go-appears at odds with the "one city, one bishop" policy.242 But closer inspection of the doctrine in practice reveals that any rules associated with canonical territory apply fast and loose, and even then, only where convenient. ${ }^{243}$ For example, the ROC is quick to denounce any perceived violation or challenge to its own self-defined canonical territory, 244 oftentimes invoking the amorphous notion of "cultural canonical territory." 245 In contrast, the Church appears to reserve

241 Patriarch Alexy II, The Russian Orthodox Church in the Modern World, 55 INT'L AFF. 49, 49 (2009).

242 See The Statute of the Russian Orthodox Church, supra note 3, pt. I, § 3 (providing that the ROC's jurisdiction includes Orthodox persons in the canonical territory of the Russian Orthodox Church as well as Orthodox Christians outside Russia who voluntarily join its jurisdiction).

243 See Bishop Hilarion of Vienna and Austria The Practical Application of the Principle of Canonical Territory, EuropaICA Bull. (Feb. 17, 2006), http://orthodoxeurope.org/page/14/87.aspx\#5 (asserting that while the principle of canonical territory is a component of Orthodox ecclesiology, it is not always applied in all locations).

244 See Shima Baradaran-Robison et al., Religious Monopolies and the Commodification of Religion, 32 PEPP. L. REV. 885, 917 (2005) (stating that the Russian Orthodox Church "has complained that foreign religions proselytize on the canonical territory' of the Church"); see also Anderson, supra note 14, at 192-93 (elaborating upon the Church's "one city, one bishop, one church," belief that because ethnic Russians are Orthodox, other Christian groups should not attempt to convert them); Constantinople Shouldn't Encroach on Canonical Territory of Other Local Churches - Moscow Patriarchate, DeP'T FOR EXTERnal CHURCH REL. OF THE MOSCOW PATRIARCHATE, http://orthodoxeurope.org/print/19/2/625.aspx (last visited Nov. 17, 2011) (criticizing the Constantinople patriarchate for setting up churches in new territories without first engaging in inter-Orthodox dialogue).

245 Bishop Hilarion of Vienna and Austria The Practical Application of the Principle of Canonical Territory, supra note 243. According to this understanding, "the overwhelming majority of Russians by their roots belong to the Orthodox tradition, and therefore Russia cannot be viewed as a free missionary territory." Id. But see Eur. Consult. Ass., Russia's Law on Religion, Doc. No. 9409 (2002), available at http://assembly.coe.int/main.asp?Link=/documents/workingdocs /doc02/edoc9409.htm (criticizing the concept of canonical territory as 
few practical limitations on its right to operate within the canonical territories of other churches. This is justified in part by an openended concept of "missionary canonical territory," which permits competition and proselytizing abroad. ${ }^{246}$

Even if tending to one's flock abroad does not necessarily contravene the canonical territory rule per se, the manner in which the ROC is pursuing this objective signals that the establishment of its churches is in no way intended to be limited or restricted ${ }^{247}$ to the narrow rationale of providing "full-fledged, effective spiritual support to its flock." 248 As noted above, one of the express purposes of the new Orthodox Church being planned in Paris is to share Orthodox "culture" with Parisians, not only parishioners. More glaringly, the ROC also has exhibited a tendency to stray beyond even the most generous reading of canonical confines, expressing open support for assisting ethnic Russians in election campaigns to legislative bodies in the European Union ${ }^{249}$ and working to "establish a dialogue between [President Medvedev's] United Russia party and the conservative forces of Europe and the USA ...." 250

"unacceptable by human rights standards" as interpreted by the Council of Europe).

246 See Bishop Hilarion of Vienna and Austria: The Canonical Territories of the Local Orthodox Churches, EUROPAICA BULL. (Feb. 6, 2006), http://orthodoxeurope.org /page/14/85.aspx\#3 (explaining that the concept of missionary canonical territory supports Orthodox missionary proselytization in areas where no local Orthodox church exists).

247 Consider some of the ROC's activities discussed at supra Section 3.2.5.2, including proselytizing in Latin America, repossession of the ROC church in Bari as a "spiritual center for promoting Orthodoxy in Italy," and construction of a new ROC church in Paris, where a longstanding Russian Orthodox congregation and several affiliated churches already exist.

248 Patriarch Alexy II, supra note 241, at 50 (stating that the church's desire to support its flock fuels its interest in maintaining relationships with state agencies in the countries where its followers live).

249 See Brian Whitmore, Russia's Patriarch Increasingly Becoming Major Force in Politics, RADIO FREE EUR. RADIO LIBERTY (Sept. 6, 2009), http://www.rferl.org/content/Russias_Patriarch_Increasingly_Becoming_Major _Force_In_Politics/1815832.html (“[Patriarch] Kirill supports the idea of helping ethnic Russians win election to legislative bodies in the European Union.").

250 Russian Church to Help Expand Dialog Between United Russia and Western Conservatives, INTERFAX (May 31, 2010, 3:48 PM), http://www.interfaxreligion.com/ ?act=news\&div $=7322$. 
Looking deeper, the effort to spread, entrench, and unify Russian Orthodoxy signals a larger purpose that relates directly to the Moscow Patriarchate's values and its perception of an unfolding existential struggle: Europe increasingly represents a secular wasteland of immoral conduct harkening back to the godless U.S.S.R., bereft of its Christian ethos, untethered from any connection to traditional Christian values. In other words, the governing state of affairs poses a threat to the ROC's continued influence and relevancy. Article 16(4) of the ROC's Bases of the Social Concept elaborates on the Church's umbrage directed against "secularization of public and social life":

The contemporary international legal system is based on the priority given to the interests of the earthly life of man and human communities over religious values .... This priority is sealed in the national legislation of many countries .... Many influential public mechanisms use the same principle in their open confrontation with faith and the Church, aimed to oust them from public life. These manifestations create a general picture of the secularization of public and social life.

[T] he Church cannot favour a world order that puts in the centre of everything the human personality darkened by sin. This is why ... the Church seeks to assert Christian values in the process of decision-making on the most important public issues both on national and international levels. She strives for the recognition of the legality of religious worldview as a basis for socially significant action (including those taken by state) and as an essential factor which should influence the development (amendment) of international law and the work of international organisations. 251

Unembellished, the ROC's overriding motivation for establishing new churches and asserting control over old ones boils down to confronting secularism: "Liberal tendencies . . make Christianity ever more vulnerable in the face of militant secularism, which

251 See The Basis of the Social Concept, supra note 47, pt. XVI.4 (emphasis omitted). 
steals from us millions of people, notably youth." 252 In other words, the Moscow Patriarchate considers its churches as the vanguard in a struggle against the drumbeat of secularism and spread of individual human rights that, in its view, neglects "relations with God" and promotes only "the protection of selfwill." 253 Notably, this struggle is not limited to the "near abroad" or even the European continent at large. In Hilarion's assessment,

It may well be the case that the entire Western civilization, not only in Europe but also elsewhere, is becoming radically anti-Christian and anti-religious. In this case there is a need of not only a pan-European but also of a universal common front formed by traditional religious confessions in order to repel the onslaught of militant secularism. ${ }^{254}$

This Manichean conflict between secularism and Orthodoxy, as the ROC sees it, leads to the second, even more profound problem with the mounting effort to acquire new and old churches: By directly advocating for and underwriting such efforts and thereby fueling the global campaign to spread Russian Orthodoxy under the guise of generic "spirituality," the Russian government is operating in direct contravention of its own constitution, and ultimately endorsing a position that strikes at the heart of the document's very legitimacy. This creates an absurd reality whereby Russia, a constitutionally secular country, advocates via its foreign policy for an ideology that at its core rejects the

252 Bishop Hilarion Alfeyev, Major Challenges for Christianity in Europe, DEP'T. OF EXTERnal Church Rel. of THE Moscow PATRIARchate (last visited Nov. 17, 2011), http://orthodoxeurope.org/print/4/1.aspx. See also Hilarion Alfeyev, European Christianity and the Challenge of Militant Secularism, 57 ECUMENICAL REV. 82, 84 (2005) ("Contemporary militant secularism, like Russian Bolshevism, views itself as a Weltanschauung destined to replace Christianity. Hence, it is neither neutral nor indifferent toward Christianity; rather, it is openly hostile to it.").

253 The Basis of the Social Concept, supra note 47, pt. IV.7 (emphasis omitted).

254 Bishop Hilarion Alfeyev, Presentation of Christianity and the Challenge of Militant Secularism Paper at the International Conference of the Australian and New Zealand Association of Theological Schools (July 5-8, 2004), http://web.archive.org/web/20110522124444/http://en.hilarion.orthodoxia.org /6_11 (last visited Nov. 17, 2011) (accessed by searching internet url on Internet Archive) (archival copy on file with the University of Pennsylvania Journal of International Law); see also infra Section 4.1 (discussing Russia's discrimination against secularism and attacks on human rights law). 
legitimacy of the state's foundation, i.e., secularism, not only as it exists in Russia, but in Europe and elsewhere in the western world.

\subsubsection{ROC as Diplomatic Lever}

The Russian government, in an effort to restore its lost role as a global superpower, has recruited the Church as a primary instrument for rallying together a dubious assortment of states and religious representatives to support a new international order. This new order is premised on the rejection of universal human rights and the revival of relativism, two principles that serve the Church well. Patriarch Kirill has characterized the urgent need to unify the "Russian world" thusly:

Alone, even the largest countries of the Russian world will not be able to defend their spiritual, cultural and civilizational interests in a globalizing world.

I believe that only a united Russian world can become a strong global actor in international politics, stronger than any political alliances. Moreover, without coordination among state, church and civil society, we will not achieve this goal. 255

But the quest for unity transcends just the "Russian world" or near abroad. As Foreign Minister Lavrov and others have reached out to the OIC to leverage the mutual objective of a ban on defamation of religion, 256 the Moscow Patriarchate has similarly sought to curry favor with the Muslim world by utilizing the same tactics. In a meeting with ambassadors from twenty Arab states, Patriarch Kirill called for Orthodoxy and Islam to become "'allies in the battle against the challenges of globalization.'"257 More specifically, in a letter directed at a group of Muslim theologians, former Patriarch Alexy called for a Christian-Muslim dialogue:

255 Text vystupleniia Sviateisheho Patrirkha Kirilla [The Text of a Speech by His Holiness Patriarch Kirill], RUSSKIY MIR FOUND., http:/ / www.russkiymir.ru /russkiymir/ru/fund/assambl/pat.html (last visited Nov. 21, 2011) (quotation translated from Russian).

256 See supra Section 3.2.4.2 (discussing Foreign Minister Layrov's alliance with the OIC); infra Section 4.1 (referring to Russia's shared goal with the OIC).

257 Patriarch Kirill to Islamic States: More Attention to Christian Minorities, AsiaNEws.IT (May 9, 2005, 10:06) http://www.asianews.it/news-en/PatriarchKirill-to-Islamic-states:-More-attention-to-Christian-minorities-16241.html. 
aimed at safeguarding the role of religion in public life, struggling with the defamation of religion, overcoming intolerance and xenophobia, protecting holy places, preserving places of worship and promoting joint peace initiatives .... Therefore, in the framework of international organizations, it seems useful to create mechanisms that make it possible to be more sensitive to the spiritual and cultural traditions of various peoples. ${ }^{258}$

The ROC has also held out the prospect of repairing ties with the Vatican and Catholic world at large on the basis of common interests related to the preservation and entrenchment of traditional Christian values. Patriarch Kirill has expressed his hope that this relationship could be harnessed to defend and assert "traditional Christian values in Europe and in the world as a whole." 259 Likewise, Metropolitan Hilarion has articulated support for the Pope's "commitment to the defence of Christian values." 260 Similar to how Kirill has called for unity within the Russian World, the Moscow Patriarchate has rallied around unity with Catholicism as a vehicle for,

propos[ing] to the world the spiritual and moral values of the Christian faith; together we will be able to offer our Christian vision of the family, of procreation, of a human love made not only for pleasure; to confirm our concept of social justice, of a more equitable distribution of goods, of a

258 Patriarch Alexy II, Response from His Holiness Patriarchy Alexy II of Moscow and All Russia to the Open Letter of 138 Muslim Theologians, A COMMON WORD (Apr. 18, 2008), http:/ / acommonword.com/en/a-common-word/6-christian-responses /202-response-from-his-holiness-patriarchy-alexy-ii-of-moscow-and-allrussia.html.

259 Patriarch Kirill Hopes for Broader Dialogue with Catholics, INTERFAx (Feb 3, 2009, 12:23), http://www.interfax-religion.com/?act=news\&div=5664. See also Dmitry Medvedev, President of Russia, Speech at a Reception Held by the President of Russia in Honour of Senior Clergy who Took Part in the Russian Orthodox Church Local Council (Feb. 2, 2009), available at http://www.cdi.org/russia/johnson/2009-22-7.cfm (explaining that the similar views of the Catholic Church and the Russian Orthodox Church about many aspects of modern life would allow them to work together to promote Christian values across the globe).

260 Neville Kyrke-Smith, In Russia, the Path to Unity is Defrosting, CATHOLIC HERALD, Jan. 22, 2010, available at http://www.knowledge-database.org /post/4553279800_5647_In\%20Russia,\%20the\%20path\%20to\%20unity\%20i.html. 
commitment to safeguarding the environment, for the defence of human life and its dignity. ${ }^{261}$

In other words, as Russia advances its search for global partners willing to counter the conventional "Western" assumption that universal human rights are applicable to all, the Moscow Patriarchate similarly echoes Moscow's message. In this vein, it has eagerly sent out feelers and urged those disenfranchised with laws that protect the rights of women, gays, freedom of expression, and freedom of religion or belief to "join us." This message is starkly evident in Metropolitan Hilarion's preface to a compilation of Pope Benedict XVI's speeches published by the ROC. Hilarion uses this opportunity to hold out an olive branch to the Vatican and propose an alliance between the Moscow Patriarchate and the Holy See. Among other things, he asserts that any civil law contradicting divine law "'ceases to be law and becomes illegal.'"262 "Obviously, disobedience of a civil law is an extreme measure . . . . It is nonetheless a possibility that must not be excluded a priori, in case a system of secularized values should become the only one operating in Europe." 263 Faced with this seemingly imminent threat, Hilarion reasons that the ROC and Catholic Church can "collaborate . . . in defending the Christian tradition against militant secularism." 264

Not by accident, the Moscow Patriarchate's book launch coincided with the announcement that Russia and the Vatican would establish full diplomatic relations. ${ }^{265}$ And, in an additional

261 Id.

262 John Thavis, Ecumenical Allies? Orthodox, Catholics Take Aim at European Secularism, CATHOLIC NeWS SERV. (Dec. 11, 2009), http://www.catholicnews.com /data/stories/cns/0905462.htm.

263 Robert Moynihan, Rome-Moscow Relations Begin New Era, ZENIT (Dec. 14, 2009), http:/ / www.zenit.org/article-27845?l=english.

264 Thavis, supra note 262.

265 See Russia and the Vatican Establish Full Diplomatic Ties, BBC News (Dec. 3, 2009, 10:59 PM), http://news.bbc.co.uk/2/hi/8394079.stm (reporting on the newly established relationship of complete diplomatic ties between Russia and the Vatican marks a significant turning point given the tenuous history of Catholics in Russia); Blitt, How to Entrench a De Facto State Church in Russia, supra note 2 at 755-56 (noting that the ROC infused political discourse with underlying ideas of Christian Orthodoxy); see also Daniel L. Schlafly, Jr., Roman Catholicism in Today's Russia: The Troubled Heritage, in RELIGIOUS LIBERTY IN NORTHERN EUROPE IN THE TWENTY-FIRST CENTURY 125, 125 (Derek H. Davis ed., 2000) (noting that before 
sign of growing proximity between the two parties, speculation continues to grow about a Pope-Patriarch meeting - an event that has not happened since the Great Schism of 1054. ${ }^{266}$ The gravitas of such a summit, according to Cardinal Walter Kasper, head of the Pontifical Council for Christian Unity, would demonstrate "to an increasingly secularized world that [the two churches] 'have the same positions on moral questions.'" 267

But the ROC's diplomatic lockstep doesn't end with entreaties to the OIC and Vatican. Evidence of its tireless political efforts to persuade international allies to join the common cause of establishing a "universal common front" to stamp out rampant secularism is omnipresent. High-level visits by foreign government officials to Russia often include a stop at the Moscow Patriarchate, and members of the ROC travel frequently within the "near abroad" and beyond to communicate a consistent message that western-influenced globalization and human rights must be challenged and even defied. ${ }^{268}$ In February 2010, Greek Prime Minister George Papandreou traveled to Moscow to discuss NATO

establishment of full diplomatic relations in the late 2000s, the Russian Orthodox and Roman Catholic Church had expressed a desire to be "sister churches").

266 See Russian Church Says No Patriarch, Pope Talks Without Ukraine Deal, RIA NovOsTI (June 9, 2010), http://en.rian.ru/russia/20100609/159361073.html (reporting on heightened speculation that the Pope and Patriarch were moving closer towards meeting); see also Patriarch's Meeting with Pope Getting NearerMetropolitan Hilarion, INTERFAX (Nov. 26, 2010, 10:03), http://www.interfaxreligion.com/ ?act=news\&div $=7957$ (reporting the Moscow Patriarchs comment that "[e]ach day brings us closer to this meeting between the Pope and Patriarch").

267 Richard Owen, Pope's Cyprus Visit 'May Lead to Summit with Russian Orthodox Church', THE TIMES (London), May 20, 2010, http://web.archive.org/web /20100526171810/http://www.timesonline.co.uk/tol/comment/faith/article713 2141.ece (accessed by searching internet url on Internet Archive) (archival copy on file with the University of Pennsylvania Journal of International Law). Accord Riazat Butt, Mormons and Catholics Join Forces, ThE GUARDIAN, Feb. 26, 2010, http://www.guardian.co.uk/commentisfree/belief/2010/feb/26/mormoncatholic-eugene-george (describing the emergence of a similar partnership between Catholics and Mormons concerned with the "increasingly secular mood" in the United States).

268 For a partial list of this extensive travel, see Chairman of Inter-Orthodox Relations of Dep't for External Church Relations of the Russian Orthodox Church, DECR Chairman Recounts His Working Trips of 2010, DEP'T FOR EXTERNAL CHURCH REL. OF THE RUSSIAN ORTHODOX CHURCH (Nov. 28, 2010), http:/ / www.mospat.ru/en/2010/11/28/news31398. 
and energy cooperation ${ }^{269}$ with Putin and Medvedev. He also met Patriarch Kirill, who used the opportunity to call on all Orthodox countries to unite in the struggle against globalization: "It is my conviction that in the globalization era we all should be concerned for the preservation of [Orthodox] civilization's special features and characteristics." 270 Kirill also applauded the Greek Orthodox Church's rejection of a European Court of Human Rights ruling banning crucifixes in Italian classrooms, as well as the government's refusal to remove icons of Jesus Christ from courtrooms and forgo using the gospel for swearing in witnesses. $^{271}$ Greece characterizes its relations with Russia as "connected with strong bonds of friendship based, among other things, on their common spiritual and cultural values."272 Given strategic and political developments in the energy sector and

269 See Papandreou, Putin Discuss Economy, Trade and Energy, NEW EUR. (Feb. 21, 2010, 7:57 PM), https://www.neurope.eu/article/papandreou-putin-discusseconomy-trade-and-energy (reporting on Papandreou's visit to Moscow, including their discussion of issues such as, economic cooperation, pipeline projects, and energy cooperation).

270 Chairman of Inter-Orthodox Relations of Dep't for External Church Relations of the Russian Orthodox Church, Patriarch Kirill Meets with Greek Prime Minister George Papandreou, DEP'T FOR EXTERNAL CHURCH REL. OF THE RUSSIAN ORTHODOX CHURCH (Feb. 16, 2010), http://www.mospat.ru/en/2010 /02/16/news13319/.

271 See Patriarch Kirill Nadeetsia Chto Rossiia I Gretsia Budut Vmeste Zashishchat Pravoslavnye Tsennosti ot Sovremennyh Ugroz [Patriarch Kirill Hopes Russia and Greece will Cooperate to Defend Orthodox Values From Threats], INTERFAx (Feb. 16, 2010), http://www.interfax-religion.ru/ ?act=news\&div=34252 (discussing Patriarch Kirill's satisfaction with the refusal of Greek authorities to remove icons from courtrooms); see also Patriarch Kirill Hopes Russia and Greece to Jointly Protect Orthodox Values from Modern Day Threats, INTERFAX (Feb. 17, 2010, 11:32), http://www.interfax-religion.com/?act=news\&div=6944 (noting that "[a]ccording to the Patriarch, the Russian Church 'approves' of the recent Greek authorities' refusal to remove icons from courtrooms and cancel oath on the Gospels" in the wake of the European Court of Human Rights ruling); Malcolm Brabant, Greek Church Acts on Crucifix Ban, BBC News (Nov. 12, 2009, 11:17 PM), http://news.bbc.co.uk/2/hi/8358027.stm (describing the Greek Orthodox Church's plea to European Christian to unite and "appeal . . . [the] ban on crucifixes in classrooms in Italy").

272 Bilateral Relations: Russia, GREECE Ministry OF FOREIGN AfF., http://www.mfa.gr/www.mfa.gr/en-US/Policy/Geographic+Regions/Russia++Eastern+Europe+-+Central+Asia/Bilateral+Relations/Russia/ (last visited Nov. 17, 2011). 
beyond, Greek-Russian relations are poised to grow in significance. 273

Kirill had a similar message in anticipation of a visit to Armenia. The purpose of the trip, in his view, was to enhance cooperation between the two countries by exploring ways to strengthen the role played by spiritual and moral values within the political realm. ${ }^{274}$ During the visit-which mixed the sacred with the secular-Patriarch Kirill and Catholicos Karekin (Garegin) II visited a Russian Defense Ministry school in Yerevan, where the patriarch "presented the school with some of his own books and works by other authors devoted to the patriarchal service." 275 Also during the visit, Patriarch Kirill met with President Serzh Sarkisian and "inaugurate[d] the start of construction of a new Russian [Orthodox] church in Yerevan ...."276 The visit also paved the

273 The Russian-Bulgarian-Greek Burgas-Alexandroupolis oil pipeline project, for instance, is intended to transport crude Russian oil from the Black Sea to the Mediterranean, although Bulgaria has raised environmental concerns. See John Helmer, Putin's Surprise Reward for Greece, and Other Friends, ATHENs NEws, Mar. 16, 2007, http://www.athensnews.gr/old_issue/13226/15877 (stating that the Burgas-Alexandropoulis pipeline project supports Russia's strategic interests "in seeing one of its natural resources safely to market"). Another Russian-initiated project, the South Stream pipeline "aimed at decreasing Europe's dependency on Russian gas." Greece Seals Pipeline Agreement with Russia, EURAcTIV (Apr. 30, 2008), http://www.euractiv.com/en/energy/greece-seals-pipeline-agreementrussia/article-172044. Both projects hold economic and political significance for Greece. See Implementation of the Burgas-Alexandroupolis Oil Pipeline and South Streem Gas Pipeline Projects is Crucial for Greece, TRANS-BALKAN PIPELINE (Dec. 8, 2010), http://www.tbpipeline.com/node/237 (noting a Greek parliamentary deputy's view that the Bargas-Alexandroupolis oil pipeline is immensely important for Greece).

274 See Patriarh Kirill Pribudet s Trehdnevnym Vizitom v Armeniiu [Patriarch Kirill arrives for a three-day visit to Armenia], RIA NovosTI (Mar. 16, 2010), http://www.rian.ru/society/20100316/214583423.html (describing the basis for political relations between Russia and Armenia as a spiritual unity of nations).

275 Inter-Christian Relations of Dep't for External Church Relations of the Russian Orthodox Church. Patriarch Kirill and Catholicos Karekin II Visit Russian Defense Ministry's School in Yerevan, DEP'T FOR EXTERnAl CHURCH REL. OF THE RUSSIAN ORTHODOX CHURCH (Mar. 17, 2010), http://www.mospat.ru /en/2010/03/17/news14640.

276 Aza Babayan \& Gayane Danielian, Russian Church Head Starts First Visit To Armenia, (Mar. 16, 2010), http://www.azatutyun.am/content/article /1985537.html. See also Patriarch of Moscow and All Russia Kirill Arrives in Armenia for a Three-Day Visit, PANARMENIAN NeTWORK (Mar. 17, 2010; 3:43 PM), http://www.panarmenian.net /eng/news/45582 (discussing Patriarch Kirill's visit to Armenia). 
way for a historic trip by Karekin II to Azerbaijan, where he, alongside Kirill and other religious leaders, discussed globalization, religion's role in public life, and the resolution of the Nagorno-Karabakh conflict. ${ }^{277}$

In a July 2009 trip to Ukraine, Kirill emphasized a message of religious unity. According to the Patriarch, "the Orthodox of Russia, Ukraine, and Belarus are aware of the importance of the spiritual unity of historical Rus (Russia), which is divided by political borders" 278 and must pray for its "unbreakable spiritual and church unity." 279 Kirill declared during the trip that " $[t]$ here is no imperialism here, no domination over others. There is only a clear Orthodox doctrine: the patriarch is everyone's father . . ." 280 These remarks, however, appeared calculated to counter efforts by the Ukrainian Orthodox Church (UOC Kyiv Patriarchate) to gain recognition for its independence from the ROC, a split supported by Ukrainian nationalists and others seeking to distance the country from Russia's traditional influence. ${ }^{281}$ Additionally, his remarks appeared to be intended to challenge the Ukrainian

277 See Armenian Church Leader in Historic Azerbaijan Visit, DAILy NEWS (Turk.) Apr. 27, 2010, http://www.hurriyetdailynews.com/n.php?n=armenian-churchleader-in-historic-azerbaijan-visit-2010-04-27 (discussing the contents of the talks between Karekin II, Patriarch Kirill, and Azerbaijan's Shiite Muslim leader).

278 Russian Church Leader Views Changes in Church, Youth, Ukraine Schism, Freedom, BBC, May 31, 2009, available at Factiva, Doc. No. BBCSUP0020090531e55v000xd (quoting Unattributed Interview, Patriarch of Moscow and All Rus Kirill to Izvestiya: "Church Life Should Be Service," IzVESTIYA (May 12, 2009)).

279 Russian Patriarch Calls for Unity with Ukraine, KYIV POsT, Jul. 27, 2009, http://www.kyivpost.com/news/nation/detail/45975. See also Maria Danilova, Russian Patriarch Calls for Unity with Ukraine, SEATTLE Times, Jul. 27, 2009, http:/ / seattletimes.nwsource.com/html/nationworld/2009543881_apeuukrainer ussiaorthodoxchurch.html (noting Patriarch Kirill's call for "brotherhood and unity between the two tense Orthodox neighbors").

280 Claire Bigg, Russian Patriarch's Visit Creates Storm In Ukraine, RADIO FREE EUROPE RADIO LIBERTY (July 31, 2009), http://www.rferl.org/content /Russian_Patriarchs_Visit_Creates_Storm_In_Ukraine/1789959.html.

281 See Nabi Abdullaev, Kirill Calls for Church Unity in Kiev, Moscow TIMES (July 28, 2009), available at http://www.cdi.org/russia/johnson/2009-141-36.cfm (noting speculation that Kirill's visit to Ukraine was motivated by the political motivations pertaining to non-recognition of the UOC Kyiv Patrarchate). However, no other Orthodox church has recognized its independence. Id. The Moscow Patriarchate, "which controls about two-thirds of Ukraine's Orthodox parishes, excommunicated the breakaway church's leader, Filaret, in 1997." Id. 
pursuit of closer ties with the West and NATO.282 At least one diplomatic cable released by WikiLeaks, confirms that the Patriarch's concern reached beyond humble religious unity to advocating on behalf of Russia's geopolitical interests. U.S. Ambassador to Russia William Burns relayed that the then Metropolitan expressed apprehension over Ukraine's bid for NATO membership, claiming that such a move could cause a split in that country's population, and create turmoil in Eastern Europe. ${ }^{283}$

Against this backdrop, remarks by UOC Kyiv Patriarchate Patriarch Filaret suggesting that the Moscow Patriarchate's presence in Ukraine was a tool of the Russian state's politics and that Kirill's visit was intended "'to promote a political project of integrating Ukraine into Russia, to promote unity under the Kremlin leadership, from which Ukraine, by God's blessing and on people's will, got rid [of] in 1991'"'284 appear less paranoid. Indeed,

282 See Bigg, supra note 280 (stating that Kirill urged Ukrainians "not to sacrifice their values in pursuit of closer ties with Europe," which was "a veiled jab at the Ukrainian efforts to move away from Russia's orbit and join NATO"); see also Brian Whitmore, Russia's Patriarch Increasingly Becoming Major Force In Politics, RAdio FreE EuROPE RAdio LiberTy (Sept. 6, 2009), http://www.rferl.org /content/Russias_Patriarch_Increasingly_Becoming_Major_Force_In_Politics/18 15832.html ("Many observers saw political undercurrents in Kirill's trip, which came as Moscow was engaged in a bitter struggle with the pro-Western government in Kyiv - and came shortly after a visit to Ukraine by U.S. Vice President Joe Biden.").

283 See generally Cable from the United States Embassy in Moscow to the United States Secretary of State (Apr. 4, 2004), available at http://www.romancatholicimperialist.org/2010/12/solzhenitsyn-andmetropolitan-kirill-on.html (reprinting a leaked telegram from Ambassador Burns to the U.S. embassy); see also Patriarch Kirill Spoke Against Ukraine's Membership in NATO-WikiLeaks, INTERFAX (Dec. 7, 2010; 1:20 PM), http://www.interfaxreligion.com/?act=news\&div=7995 (reporting a leaked telegram of Ambassador Burns describing Kirill's sentiment that "Ukraine was 'not ready,' and NATO membership could cause a split in that country's population, and create[] turmoil in Eastern Europe").

284 Rebel Cleric Says Patriarch Kirill Plots to Merge Ukraine, Russia, RIA NovOSTI (July 27, 2009), available at http://www.shebacss.com/en/media-center27138.html. See also Lyudmila Alexandrova, Russian Patriarch's Visit To Ukraine Getting Increasingly Politicized, ITAR-TASS (July 30, 2009), available at http://emm.newsexplorer.eu/NewsExplorer/clusteredition/en/20090730,itartas s_en-192d9244707bb9c13b80bfd1f967ef5e.html (stating that Ukrainian politicians politicized the visit in the lead up to elections). For a contradictory assessment viewing the visit as absent of such political motivations, see Andrei Zolotov, Jr., 
even as the controversy raged with "[s]cuffles and heated arguments" between pro-UOC Kyiv Patriarchate demonstrators and ROC worshippers, Kirill found time to reiterate the Kremlin's condemnatory talking point regarding Ukrainian attempts to "'falsify' history" by seeking international recognition of the Holodomor, a Stalin-era famine that killed millions of Ukrainians, as a crime of genocide. ${ }^{285}$

In the wake of Kirill's trip, Medvedev quickly fired off an angry missive to then Ukrainian president Viktor Yushchenko, which included, accusing him of spoiling Russian-Ukrainian relations through his "stubborn" drive to join NATO, criticism of Ukrainian efforts at "historical revisionism," and disapproval of other policies. Not coincidentally, Medvedev specifically called attention to Ukraine's "harmful practices of intervention . . . in the affairs of the Orthodox Church" and deemed unfavorable the "conditions that were created artificially on the eve and during a recent pastoral visit to Ukraine by Patriarch Kirill of Moscow and All Russia." 286 He further elaborated that due to "the anti-Russian position of the current Ukrainian authorities," his letter announced his intention "to postpone sending a new Russian ambassador to Ukraine" until a "new political leadership" signaled its readiness "to build relations between our countries." 287 Such statements establish that any perceived mistreatment of the Moscow Patriarchate will be considered an equal affront to Russia's secular government. This new leadership appears to have emerged with the February 2010 election of Kremlin-friendly President Victor Yanukovich. ${ }^{288}$ Indeed, since Yushchenko's defeat, the Moscow

Kirill on a Mission, JOHNSON'S RUSSIA LIST (July 27, 2009), http://www.cdi.org/russia/johnson/2009-141-37.cfm.

285 Bigg, supra note 280. For further information regarding Russia's new Commission to Prevent Falsification of History, see Blitt, One New President, supra note 2 , at 1361-63.

286 Dmitry Medvedev, President of Russia, Address to President of Ukraine Victor Yushchenko (Aug. 11, 2009), http://archive.kremlin.ru/eng/text/docs /2009/08/220759.shtml.

287 Id. Russian frustration with Ukraine dates back to the 2004 Orange Revolution.

288 See Luke Harding, Viktor Yanukovych Promises Ukraine Will Embrace Russia, THE GUARDiAN (London), Mar. 5, 2010, http://www.guardian.co.uk/world/2010 /mar/05/ukraine-russia-relations-viktor-yanukovych ("Yanukovych said he 
Patriarchate has undertaken several return visits to Ukraine, most notably two back-to-back trips in November 2010, where ROC officials met with both religious and state officials, including the new president.289 At the meeting between Kirill and Yanukovich, the Patriarch heralded the Ukrainian election as having "already been of visible benefit to the people of the country" and thanked Yanukovich for his attention to the needs of the Ukrainian Orthodox Church of the Moscow Patriarchate. ${ }^{290}$

Another example of the Church's international diplomatic interventions is telling for what is missing. In March 2010, Metropolitan Hilarion traveled to France as part of President Medvedev's official delegation. Hilarion's schedule was demanding: a "grand reception at the City Council" with the Mayor of Paris to discuss cooperation matters including the

would perform a sharp U-turn on the policies pursued by his predecessor, Viktor Yushchenko, whose pro-west and pro-NATO stance infuriated the Kremlin.").

289 See Metropolitan Hilarion of Volokolamsk Meets with His Beatitude Metropolitan Vladimir of Kiev and All Ukraine, DEP'T FOR EXTERNAL CHURCH REL. OF THE RUSSIAN ORTHODOX CHURCH (Nov. 16, 2010), http://www.mospat.ru/en /2010/11/16/news30506/ (describing the meeting as a "cordial fraternal atmosphere [where] the hierarchs discussed topical issues of ecclesiastical life in Ukraine."); His Holiness Patriarch Kirill arrives in Kiev to Celebrate 75th birthday of His Beatitude Metropolitan Vladimir, DEP'T FOR EXTERNAL CHURCH REL. OF THE RUSSIAN ORTHODOX CHURCH (Nov. 23, 2010), http://www.mospat.ru/en /2010/11/23/news31077/ (describing the Moscow Patriarchate's second November trip to Ukraine); see also Pavel Korobov et al., Patriarch Kirill Explores a Canonical Territory, RT (Jul. 21, 2010), http://rt.com/politics/press /kommersant/patriarch-kirill-explores-a-canonical-territory/en (describing Kirill's attendance of Yanukovich's inauguration and other visits to the Ukraine); Patriarch Kirill Of Moscow To Attend President-Elect Yanukovych's Inauguration On February 25, FINANCIAL (Geor.), Feb. 22, 2010, http://www.finchannel.com /Main_News/Ukraine/58874_Patriarch_Kirill_Of_Moscow_To_Attend_President -Elect_Yanukovych\%27s_Inauguration_On_February_25_ (noting Patriarch Kirill's intention to attend then President Elect Yanukovych's inauguration).

290 Patriarch Kirill meets with Ukrainian President Victor Yanukovich, DEP'T FOR EXternal CHURCh Rel. of THE Russian Orthodox CHURCH (Nov. 23, 2010), http://www.mospat.ru/en/2010/11/23/news31136/. See also Patriarch Filaret Advised Patriarch Kirill to Recognize Autocephaly of Ukrainian Church, RELIGIOUs INFO. SERV. OF UKRAINE (Nov. 10, 2010), http://risu.org.ua/en/index/all_news /confessional/orthodox_relations/38877/ (describing an interview with Voice of America where Patriarch Filaret maintained that Russia expects nothing less than "unification of Ukrainian Orthodoxy and annexation thereof to Moscow"). 
construction of the new Russian Orthodox Church,291 inauguration of the Holy Rus exhibition at the Louvre, and an official dinner hosted by President Sarkozy in honor President Medvedev. ${ }^{292}$ However, amidst all the socializing with France's political elite, the Metropolitan found little time to engage in spiritual endeavors. When asked whether he met with any of Orthodox hierarchs from Paris, Hilarion flatly replied: "No . . . . I had been supposed to serve at the Cathedral of St. Alexander Nevsky in rue Daru . . . but a week before the appointed date I received a letter from Archbishop Gabriel informing me that my visit to the cathedral had to be put off until better times." 293

Yet Hilarion himself has claimed that the Moscow Patriarchate is "present in the international sphere not to acquire an influence but to bring the word of the Truth to people, to point to the importance of the moral dimension of human life and of spiritual and cultural values in building a sustainable human common life in justice."294 Surely, this is better achieved in church rather than over Roquefort and Château Margaux at the Palais de l'Elysée. Moreover, even if one is able to claim that the Church's mission is preserved amid black-tie exhibition openings and amuse-bouches, the Russian government-as constituted under a secular constitution reflecting the popular will of the people-is acting ultra vires by underwriting or facilitating even this humble calling.

291 DECR Chairman Attends Grand Reception Given on the Occasion of Russian President's Visit to France, DECR COMMC'N SERV. (Mar. 2, 2010), http://hilarion.ru/en/2010/03/03/1360.

292 See DECR Chairman Completes His Visit to France, DECR COMMC'N SERV. (Mar. 3, 2010), http://hilarion.ru/en/2010/03/03/1367 (reporting Metropolitan Hilarion's participation in the inauguration of an exhibit at the Louvre and his attendance at an official dinner).

293 Metropolitan Hilarion of Volokolamsk's Interview to Interfax-Religion Portal, DEP'T FOR EXTERnAl CHURCh Rel. OF THE Russian Orthodox CHURCH (Mar. 4, 2010), http://www.mospat.ru/en/2010/03/04/news14104. See also Dmitry Medvedev's Visit to the Cathedral of Notre Dame de Paris is Unforgettable Event, INTERFAX (Mar. 5, 2010), http://www.interfax-religion.com/?act=interview \&div=77 (mentioning that the times were not better because of legal action).

294 Pavel Korobov, Ethics as Politics. Interview with Bp. Hilarion of Volokolamsk, ORTHODOXY TODAY (Dec. 25, 2009), http://www.orthodoxytoday.org/articles2009/Korobov-Ethics-As-Politics-Interview-With-Bp-Hilarion-Of-

Volokolamsk.php. 


\section{THE IMPLICATIONS OF "ORTHODOX" RUSSIAN FOREIGN POLICY ABROAD AND AT HOME}

\subsection{Challenging Established Human Rights Norms within the International System}

The pattern outlined in the previous section illustrates the overlap in vision and the depth of cooperation shared by the government of Russia and the ROC on the international stage.295 It also underscores the extent to which the current government's activities abroad have flouted the constitutional promises of secularism, separation, and nondiscrimination endorsed by the Russian people in 1993. Beyond its vigorous promotion of Orthodox interests abroad, the MOFA also has championed foreign policy positions that, in addition to boosting the ROC's influence, seek to challenge longstanding principles of international human rights law. The church-state partnership exhibited on this front exposes more fully the international ramifications of the breakdown in Russia's respect for its constitutional secularism.

Since President Putin took office, the Russian government has sought to limit the impact of existing international human rights norms at home and abroad. President Medvedev has continued this policy and the ROC has devotedly followed suit, at times arguably leading the campaign. According to Foreign Minister Lavrov, the ROC's treatise On Human Dignity, Freedom and Rights "has substantially contributed to addressing" efforts to tie "criteria for civil rights and liberties" more closely to "the individual's responsibility to society." 296 The purported message is thus clearly echoed by the ROC and government alike: universal human rights norms are western norms. The existing international system is biased and must account for traditional (religious) values. Two international campaigns sponsored by Russia at the U.N. are particularly relevant examples here.

295 In a scathing essay, longtime Russia scholar Vladimir Shlapentokh has argued, "[t] he patriarchs [Alexy II and Kirill] and the whole army of priests across the country [have become] ardent propagandists of the regime and troubadours of Putin as the "national leader."' Vladimir Shlapentokh, Putin is Much Smarter Than the Soviet Leaders: What is Behind His High Rating?, JOHNSON's Russia LisT (Jul. 1, 2009), http:/ / www.cdi.org/russia/johnson/2009-122-34.cfm.

296 Diplomacy Needs a Moral Foundation, supra note 45, at 3. 
In the first case, Sergei Lavrov has celebrated that Russian "diplomats and clerics alike are allies" 297 in the ten-year effort to prohibit defamation of religion at the U.N. ${ }^{298}$ This ongoing venture seeks to cloak domestic anti-blasphemy measures in the rhetorical legitimacy of international human rights law. Russia's U.N. mission consistently has voted in favor of defamation resolutions in the U.N. General Assembly and Human Rights Council, even going so far as to endorse new restrictions on the right to freedom of expression, despite such limits being unrecognized by the International Covenant on Civil and Political Rights. ${ }^{299}$

The new norm Russia aspires to install, together with the help of the OIC and ROC, 300 would provide international justification for the already dubious domestic practice of censuring religious dissenters and minority faiths, as well atheists and nonbelievers, deemed to run afoul of the dominant, state-sanctioned religious perspective. ${ }^{301}$ And yet, the effort to advance defamation of

297 Id.

298 For a more detailed treatment of the problems associated with banning "defamation of religion," see Robert C. Blitt, Should New Bills of Rights Address Emerging International Human Rights Norms? The Challenge of "Defamation of Religion," 9 NW. U. J. INT'L HUM. RTS. 1-26 (2010).

299 See G.A. Res. 61/164, ๆ 9, U.N. Doc. A/RES/61/164 (Feb. 21, 2007) (endorsing limitations on free expression where necessary for, inter alia, "respect for religions and beliefs"); Press Release, General Assembly, General Assembly Adopts 46 Third Committee Texts on Human Rights Issues, Refugees, SelfDetermination, Racism, Social Development, Annex XII, U.N. Press Release GA/10562, available at http://www.un.org/News/Press/docs/2006 /ga10562.doc.htm (indicating that Russia affirmatively voted in favor of a proposed resolution "combating the defamation of religions"). But See International Covenant on Civil and Political Rights, art. 19, Dec. 19, 1966, 999 U.N.T.S. 172 (providing for full freedom of expression subject to only very limited exceptions).

300 For the ROC's role advancing this effort see supra Section 3.2.5.3.

301 Joint statement by Mr. Githu Muigai et al. on Freedom of Expression and Incitement to Racial or Religious Hatred at the OHCHR Durban Review Conference 2 (April 22 2009), http://www2.ohchr.org/english/issues/racism /rapporteur/docs/Joint_Statement_SRs.pdf (noting that defamation of religion has "often proved to be applied in a discriminatory manner" and that " $\mathrm{t}$ ] here are numerous examples of persecution of religious minorities or dissenters . . . [as well ass] atheists and non atheists"). Not surprisingly, Russia itself has already prosecuted several cases of alleged blasphemy against the Russian Orthodox Church on the basis of incitement to religious hatred. For examples of such prosecutions, see Blitt, How to Entrench a De Facto State Church in Russia, supra note 2, at 757; infra Section 4.2. 
religion persists despite the fact that a panel of U.N. special rapporteurs on human rights has concluded "the difficulties in providing an objective definition of the term 'defamation of religions' at the international level make the whole concept open to abuse." 302 Indeed, despite ten years and dozens of resolutions expressing support for prohibiting defamation of religion, neither the U.N. General Assembly nor the Human Rights Council has ventured to undertake the task of outlining a workable definition of the offense. ${ }^{303}$

Coupled with its efforts to legalize an ill-defined prohibition against defamation of religion, Russia also has initiated a broader attack on the universal foundation of human rights law. This second international campaign-which Patriarch Kirill has the distinction of having launched during his address to the U.N. $\mathrm{HRC}^{304}$ - manifests itself through a concerted effort to make the interpretation of universal human rights subject to traditional values, another open-ended and undefined catchall term intended to empower religious relativism. Following Kirill's controversial speech, the Russian government directed itself to turning words into deeds by drafting an HRC resolution entitled, "Promoting Human Rights and Fundamental Freedoms Through a Better Understanding of Traditional Values of Humankind." Although Russia's first attempt to pass the resolution at the Council's 11 th session faced opposition, 305 rather than abandon the effort,

302 Muigai et al., supra note 301, at 2.

303 See Blitt, supra note 298, at 4 (discussing the possibility of "defamation of religion" being identified as an emerging norm). Because of complications associated with defining defamation of religion, there has been much effort spent blurring the boundary between defamation of religion and the more legally coherent concept of incitement. Id. at 16.

304 According to Interfax, the Traditional Values resolution was "an outcome of discussions [that] began in March 2008 with a panel on "The Intercultural Dialogue on Human Rights.'" See The UN Human Rights Council takes a stand for a better understanding of traditional values of humankind, INTERFAX (Oct. 28, 2009), http://www.interfax-religion.com/?act=news\&div=6587 (noting that the significance of the resolution drafted by Russia was to exchange opinions and gain a greater understanding regarding the common values of humankind); see also infra Part 3.2.4.3 (discussing Kirill's address).

305 See U.N. Human Rights Council, Promoting Human Rights and Fundamental Freedoms Through a Better Understanding of Traditional Values of Humankind, U.N. Doc. A/HRC/11/L.1 (providing the draft resolution). The operative part of this draft resolution called for the U.N. High Commissioner for Human Rights "to 
Ambassador Loshchinin opted to defer consideration of the draft and pledged to press forward at the next session. ${ }^{306}$ This perseverance paid off several months later when the Council passed the "traditional values" resolution by a recorded vote of 26 to 15 , with six abstentions. ${ }^{307}$

The operative part of the resolution sets the ostensibly humble goal of convening "a workshop ... on how a better understanding of traditional values of humankind underpinning international human rights norms and standards can contribute to the promotion and protection of human rights and fundamental freedoms." 308 The problem inherent in the resolution was evident to the Norwegian delegation, which voted against the initiative because it "could undermine the struggle for equality among men and women."309 Likewise, France, representing the European Union, expressed its "deep" conviction that "the concept of traditional values was something that could render human rights more vulnerable ... [and] could be used to weaken human rights, as enshrined in international instruments." 310

bring the present resolution to the attention of all Member States of the United Nations, to seek their views and opinions on the issue of promoting human rights and fundamental freedoms through a better understanding of the traditional values of humankind, and to submit a report thereon ...." Id. at 2.

306 See U.N. Human Rights Council, Human Rights Council Establishes Mandate of Independent Expert On Sudan For One Year, June 18, 2009, http://www.ohchr.org/en/NewsEvents/Pages/DisplayNews.aspx?NewsID=89 $50 \&$ LangID $=\mathrm{E}$ (describing Loshchinin's statements that Russia was committed to finding a compromise and therefore had "decided to defer the draft resolution to the next session").

307 See Promoting Human Rights and Fundamental Freedoms Through a Better Understanding of Traditional Values of Humankind, G.A. Res. 12/21, U.N. Doc. A/HRC/12/21 (Oct. 12, 2009) (describing the resolution and naming the countries that voted in favor, against, or abstained from voting on the resolution).

308 Id. para. 1.

309 Press Release, Human Rights Council, Human Rights Council Adopts Six Resolutions and One Decision On Discrimination Against Women and Freedom of Expression, Among Others (Oct. 2, 2009), available at http://www.unhchr.ch /huricane/huricane.nsf/view01/6A69FF0F95283CE7C12576430046793B?opendoc ument (summarizing the reasoning behind Norway's vote against the resolution as stemming from gender equality struggles).

$310 \mathrm{Id}$. 
The workshop itself, a seminar on "Traditional Values and Human Rights," convened in Geneva in October 2010,311 provided yet another U.N. forum for Russia to expound its curious vision of an Orthodoxy-infused global order which rejects the legitimacy of existing human rights norms. The selection of Natalia Narochnitskaya, from the Paris-based Institute for Democracy and Cooperation (IDC), as Russia's ostensibly "nongovernmental" official speaker at the seminar is particularly revealing, not only for the content of her remarks, but also for the affiliations she represents. The Kremlin established the IDC in 2008 in an effort to counter Western criticisms concerning Russia's human rights record, by mandating it with a work program intended to scrutinize democracy and human rights practices in Europe and the United States. Although the Kremlin has denied funding the organization directly, its work is being supported by unnamed private businesses.312 According to some observers, the IDC "is little more than another image-building tool for a Kremlin desiring a more prominent place in world affairs." 313 As for Narochnitskaya, her political philosophy has been described as being cut from the "basis of various aspects of Orthodox Christianity." 314 Among other positions, 315 she has called for

311 See generally Office of the High Commissioner For Human Rights, Provisional Agenda, The Traditional Values Underpinning International Human Rights: How Can They Contribute to Promotion and Protection? (Oct. 4, 2010) (archival copy on file with the University of Pennsylvania Journal of International Law) (providing the conference agenda).

312 See New Russian Think Tank to Question West Ways, MSNBC, Jan. 28, 2008, http://www.msnbc.msn.com/id/22885961/ns/world_news-europe (noting that although the Kremlin approved the organization, it is funded through donations from private businesses). The IDC website provides no information regarding its funding sources. See generally Institut de la Démocratie et de la Coopération Home Page, http://www.idc-europe.org/index.asp (last visited Nov. 18, 2011).

313 Alex Rodriguez, Citing U.S. Hypocrisy on Rights, Russia Takes Lectern, Chicago TRIBUne, Mar. 27, 2008, http://articles.chicagotribune.com/2008-0327/news/0803260749_1_human-rights-kremlin-backed-human-rights-watch (noting the opinions of the new Kremlin academic think tank on Western democracy and how committed the West is to the protection of human rights on U.S. soil).

314 SHIREEN Hunter et AL., Islam In Russia: The POlitics OF IDENTITY AND SECURITY 180 (2004).

315 For a recent interview with Narochnitskaya, see Esteban Villarejo, A los Liberales Rusos de los Años 90 se les Identifica Como Enemigos de la Nación [The Russian Liberals of the 1990s are Considered Enemies of the Nation], ABC (May 
Russia to rebuild itself without reliance on abstract universal ideas, but instead to develop a political order premised on its Orthodox heritage:

Those who know what is felt by a believer during inspired prayer at liturgy know perfectly well the feeling of belonging to an Orthodox Church - which joins with Christ all believers, those who are dead, those who are living, and those who are to be born. Let us strive for a similar hallowed feeling of belonging to our Fatherland. 316

Narochnitskaya's connections to the ROC and current Russian government run deeper still. It is probably no small coincidence that she happens to sit alongside Metropolitan Hilarion and Foreign Minister Lavrov on Russkiy Mir's Board of Trustees, 317 and also has participated in other high-level meetings with ROC officials to develop policies aimed at increasing the role of religious traditions in "shaping of international legal standards" related to human rights. ${ }^{318}$

26, 2009), http://www.abc.es/20090526/internacional-europa/liberales-rusosanos-identifica-20090526.html (English translation available at http://02varvara.wordpress.com/2009/07/13/) (providing Narochnitskaya's insights into Russia's current political environment in relationship to the world, specifically noting that "the future of Russia is the future of Europe"); see also Mufti Ashirov's Statements about the Russian Church Offend a Whole People and Make Ground for a LegalSsuit-MP, INTERFAX (Feb. 22, 2007), http://www.interfaxreligion.com/ ?act=news\&div=2637 (indicating Narochnitskaya's displeasure with comments comparing the teachings of Orthodox Culture to the teachings of MEIN KAMPF).

316 Ethan Alexander-Davey, The Rebirth of Russian Conservatism, 44(4) UNIVERSITY BOOKMAN (2006) (book review), available at http:/ / www.kirkcenter.org /index.php/bookman/article/the-rebirth-of-russian-conservatism/ (quoting excerpt from Natalia Narochnitskaya, QUE RESTE-T-IL DE NOTRE VICTOIRE? RUSSEOCCIDENT: LE MALENTENDU [WHAT We FOUGHT FOR AND WHOM WE FOUGHT WiTH] (2008)); see also Institut de la Démocratie et de la Coopération Home Page, http://www.idc-europe.org/showerInformation.asp?Identificateur=1.

317 See RUSSKIY MIR FOUND., supra note 82 (listing Narochnitskaya as part of the foundation's board of trustees).

318 See Archbishop Hilarion Chairs a Meeting on the Preparation of the "International Law and Religious Traditions. Potential for Cooperation" Seminar, DEP'T FOR EXTERNAL CHURCH REL. OF THE MOsCOW PATRIARCHATE, http://orthodoxeurope.org/page/19/2/857.aspx (last visited Nov. 18, 2011) (summarizing the purpose of the meeting as the development of dialogue between religious communities and the Council of Europe institutes). 
With this above context in place, it is not surprising to find that Narochnitskaya's prepared remarks to the workshop participants read as if penned by the MOFA-ROC working group. After congratulating the HRC for its approach to human rights that avoids the "quest to force all cultures into a one-dimensional, uniform and inevitably sterile matter with no spiritual impetus," she argued that the "loudest human rights promoters tend to make traditional values, and those moral criteria which derive from religion . . . the main object of their attacks." 319 Because of this phenomenon, Europe today is confronting "a self-destructing departure from its civilizational roots, "and an unnatural separation of human rights from traditional and moral values." 320 Consequently, Narochnitskaya concludes that Russia - and Europe too-must restore "national, traditional and religious values, which embody a distinct perception of sin and virtue" as a basis for civil and political freedoms. ${ }^{321}$

The ROC delegation's remarks made from the floor reinforced Narochnitskaya's views with practical steps that could be introduced to ensure a greater role for traditional values in defining human rights. Deputy Chairman of the Department for External Church Relations, Abbot Philip (Ryabykh), suggested that the international community should develop a code of conduct to protect religious traditions in the public arena, as well as measures that would hold the media accountable for dissemination of information deemed defamatory of religion. He further argued that the "ideological monopoly" in human rights must yield to a greater role for religious values, which in turn must reject the "third generation" rights alluded to by Narochnitskaya322 namely, the rights to sexual orientation, euthanasia, and abortion. Finally, in an effort to justify the ROC's discriminatory approach to

319 Natalia Narochnitskaya, Inst. for Democracy and Cooperation, Opening Remarks at the Seminar on Traditional Values and Human Rights (Oct. 4, 2010), available at http://www.idc-europe.org/en/IDC-at-United-Nations-.

320 Id.

321 See id. (arguing that many have exploited human rights for political ends and that the worst violators of human rights have been anti-traditional and antiChristian).

322 According to Narochnitskaya, third generation rights are "those inscribed on the Messianic banners of the present-day 'libertarian revolution'. These are the rights of any individual to indulge in any form of extravagant behaviour." Id. 
interreligious dialogue-as well as the composition of Russia's envisioned international consultative council of religions - Abbot Philip reasoned that advocating beliefs common to "major religious traditions" does not require representation from all religions. ${ }^{323}$

To her credit, U.N. High Commissioner for Human Rights, Navanetham Pillay, reminded seminar participants of the universal foundation for human rights, and the fact that the principles enshrined within this legal framework reflect truly universal notions that transcend religion and tradition:

What else could be expected of a [Universal Declaration of Human Rights] drafted by men and women with names like Chang, Malik, Cassin, Humphreys and Roosevelt, and based on a project that drew from cultures and traditions across the world, and surveyed a range of thinkers, from Huxley to Gandhi.

Of course, there will always be those who, for their own political or personal designs, would deny the universality of our rights, and seek to use arguments of tradition and culture to oppose them. To them I say, speak to my staff who work in every corner of the globe defending human rights. Ask them if, in any of the 192 Member States of this Organization any single woman, man or child has ever stood to demand the right to be tortured, summarily executed, starved or denied medical care, in the name of their culture. ${ }^{324}$

\footnotetext{
323 See $V$ Sovete OON po pravam cheloveka proshchel seminar, posviashchennyi pravam cheloveka I traditsionnym tsennostiam [U.N. Human Rights Council Seminar on Human Rights and Traditional Values], DEP'T. FOR EXTERNAL CHURCH REL. OF THE RusSiAN ORTHODOX CHURCH (Oct. 5, 2010), http://www.mospat.ru/ru /2010/10/05/news27330/ (arguing that religion embodies universal values, such as freedom, and human dignity, and that it is thus in harmony with the notion of human rights); see also Seminar on Traditional Values and Human Rights, INT'L SERVICE FOR HUMAN RIGHTS (Oct. 4, 2010), http://www.ishr.ch/archivecouncil/931-seminar-on-traditional-values-and-human-rights (summarizing the seminar's proceedings from the perspective of a Geneva-based human rights NGO).

324 Navanethem Pillay, Seminar on Traditional Values and Human Rights: Opening Statement by Navanethem Pillay High Commssioner for Human Rights (Oct. 4, 2010), http://www.ohchr.org/en/NewsEvents/Pages
} 
Despite High Commissioner Pillay's rhetoric, the Orthodoxyinfused foreign policy currently advocated by Russia has serious implications on the international level for supporters of existing human rights norms and institutions. The movement to entrench a ban on defamation of religion risks impeding freedom of thought, conscience, religion or belief and reducing the free exchange and expression of ideas on a global level. 325 Furthermore, by insisting on a role for so-called "traditional values" in informing universal human rights norms, Russia has sanctioned the unlocking of a Pandora's box full of detrimental practices such as female genital mutilation $^{326}$ and discrimination against women and religious minorities - to say nothing of Orthodox traditional values that reject rights for homosexuals, "non-traditional religions," and others. As Patriarch Kirill has asserted:

The [Orthodox] religious tradition . . . contains a criterion for discerning good from evil. From the perspective of this tradition, the following cannot be accepted as normative: mockery of sacred things [i.e., blasphemy], abortion, homosexuality, euthanasia and other actions that are actively advocated today by the concept of human rights. ${ }^{327}$

The timing of Russia's dubious initiative comes at a critical juncture, where the campaign to eliminate the use of "tradition" as a justification for such abusive customs both within the United Nations and elsewhere has made discernable progress. For

/DisplayNews.aspx?NewsID=10413\&LangID=e (advocating the use of traditional values to support human rights in certain regions). Following this seminar, the HRC requested that its Advisory Committee establish a drafting group tasked with preparing "a study on how a better understanding and appreciation of traditional values of dignity, freedom and responsibility could contribute to the promotion and protection of human rights." See Report of the Advisory Committee On Its Seventh Session, UN Doc. A/HRC/AC/7/4 (Sept. 2, 2011), available at http://www2.ohchr.org/english/bodies/hrcouncil/advisorycommittee/docs/se ssion7/reportAC_AEV.doc.

325 For more on this issue, see Blitt, supra note 157 (providing more information about defamation of religion).

326 See U.N.H.C.R., supra note 158 (stating that the term "traditional values" is often used to justify many harmful practices, such as female genital mutilation).

327 See Metropolitan Kirill of Smolensk and Kaliningrad: Human Rights and Moral Responsibility, paper read at the X World Russian Peoples Council, INTERFAX (Apr. 4, 2006), http:/ / www.interfax-religion.com/?act=documents\&div=62 (stating that human rights in the modern era has trampled morality) (emphasis added). 
example, the United Nations newly established Entity for Gender Equality and the Empowerment (U.N. Women) is focused on "accelerat[ing] progress in meeting the needs of women and girls worldwide." 328 These needs necessarily include ensuring "States should condemn violence against women and should not invoke any custom, tradition or religious consideration to avoid their obligations with respect to its elimination" 329 - a position reiterated by the Beijing Declaration and Platform for Action,,330 and which underscores the approach to harmful traditional practices taken by the Committee to Eliminate Discrimination Against Women. ${ }^{331}$ Echoing these views, "The Elders," an independent group of eminent global leaders organized by Nelson Mandela to "help address major causes of human suffering and promote the shared interests of humanity," 332 has concluded that "the justification of discrimination against women and girls on grounds of religion or

328 See Directory of UN Resources on Gender and Women's Issues, WOMEN WATCH, http://www.un.org/womenwatch/directory/UN_entities_10.htm (last visited Nov. 18, 2011) (listing U.N. organizations that incorporate gender issues into their work).

329 See Declaration on the Elimination of Violence against Women G.A. Res. 48/104, U.N. Doc. A/RES/48/104, art. 4 (Feb. 23, 1994), available at http://www.unhchr.ch/huridocda/huridoca.nsf/\%28symbol\%29/a.res.48.104.en (affirming that violence against women constitutes a violation of a fundamental right and urging states to adopt policies to eliminate such acts).

330 See Beijing Declaration and Platform for Action, adopted at the 16th plenary meeting, para. 124(a) (Sept. 15, 1995), available at http://www.un.org/womenwatch/daw/beijing/pdf/BDPfA\%20E.pdf ("Condemn violence against women and refrain from invoking any custom, tradition or religious consideration to avoid their obligations with respect to its elimination as set out in the Declaration on the Elimination of Violence against Women.").

331 See generally International Human Rights Instruments, Compilation of General Comments and General Recommendations Adopted by Human Rights Treaty Bodies, I 14, 19, U.N. Doc. HRI/GEN/1/Rev.7 (May 12 2004), available at http://www.unhchr.ch/tbs/doc.nsf/0/ca12c3a4ea8d6c53c1256d500056e56f/ \$FIL E/G0441302.pdf (recommending that states prevent female circumcision and violence against women).

332 See About the Elders, THE ELDERS, http://www.theelders.org/about (last visited Nov. 18, 2011) (explaining that the organization consists of a group of leaders who are not tied to the interests of any one nation and who promote human rights). 
tradition, as if it were prescribed by a higher authority, is unacceptable." 333

Reinforcing this trend, the 2004 Arab Human Development Report (ADHR), written by an independent group of Arab scholars, policymakers and practitioners, observed that:

[I]n Arab countries the issue of "specificity" is frequently raised to weaken international human rights law ... traditional interpretations of Shari' a [Islamic law] are used to argue that international human rights laws [relating to issues such as capital punishment, gender equality, and the treatment of religious minorities] are not applicable in Arab countries. ${ }^{334}$

The ADHR also found that "Official models of belief that bolster tradition and traditional values and negate freedom of opinion, treat those who do not conform to them as enemies." 335 In a similar vein, the follow-up 2005 AHDR concluded-under the heading "Traditional Religious Heritage Promotes and Reinforces the Existing Gender Hierarchy" - that "Arab women are ... demeaned not only by conservative and traditional jurisprudential interpretations but also by sayings, myths and proverbs that confine them to a particular place in society." 336

\footnotetext{
333 See Press Release, Religious and Traditional Practices Discriminate Against Women and Girls, THE ELDERS (Jul. 2, 2009), http://www.theelders.org/article/religious-and-traditional-practicesdiscriminate-against-women-and-girls (asking men and boys to alter their traditional and religious practices so that women are not harmed).

334 See Arab Human Development Report 2004, supra note 166, at 13 (explaining that some traditional interpretations of Shari'a argue that minor differences between Islamic law and human rights law prevent the latter from applying to Arab countries).

335 Id. at 89.

336 United Nations DeVElopment Programme (U.N.D.P.), The Arab Human DEVELOPMENT REPORT 2005: TOWARDS THE RISE OF WOMEN IN THE ARAB WORLD 147 (2006). As part of its recommendations for addressing concerns related to harmful traditional practices, the 2004 AHDR considered harmonizing the interpretation of Islamic law in a manner that ensures respect for international human rights law "in its entirety, while recognizing the Arab national identity and its aspirations." See ARAB HumAn DEVELOPMENT REPORT 2004, supra note 166, at 75 (describing the belief that the most promising argument for reconciling Islam and international human rights law is the theory that the welfare of Muslim nations will improve if they follow international human rights standards).
} 
This collective reasoning articulates one vital proposition: the preservation and advancement of universal human rights requires that detrimental practices not be shielded from international scrutiny or justified on the basis of custom, tradition, religion, or other parochial value. Yet, as demonstrated above, Russia's openended effort to reinvigorate a religion-driven relativism seeks the inverse by breathing new life into the suspect notion of variable standards, thus threatening not only the coherence of international human rights law, but also the efficacy of the institutions designed to uphold its norms.

\subsection{Using International Developments to Reinforce Adverse Human Rights Situation at Home}

In addition to destabilizing established international human rights norms, Russia's Orthodox foreign policy has equally damaging consequences on the home front. The government and ROC are actively using the challenge mounted against these norms on the international level as further justification for the reinforcement of hostility to human rights at home. This is evident across a variety of areas-including minority rights and the prosecution of "defamation of religion" offenses-and is exacerbated by the severe bureaucratic restrictions imposed on human rights NGOs under the government's amended NGO law. ${ }^{337}$ These amendments are designed to hinder the ability of human rights organizations to operate freely in Russia. However, when coupled with Russia's international efforts to undercut the authority of existing international human rights law, the climate for human rights groups in Russia becomes not only hostile for conducting operations, but one where the very legitimacy and even patriotism of that work is brought into question.

Russia's effort to build currency for the notion of "traditional" religions on the international level, seen through its UNESCO interactions and other activities at the U.N., reinforces its existing domestic three-tiered system for distinguishing between Russian Orthodoxy, Islam, Buddhism and Judaism (as other "traditional" faiths), and the so-called "non-traditional" religions. In practice,

337 Amendments to the NGO law in 2006 garnered the ROC's outspoken support. See Blitt, How to Entrench a De Facto State Church in Russia, supra note 2, at 747-48. 
this pattern legitimates discrimination at odds with the constitutional text and prevents individuals from freely observing their faith. For example, rather than urge or require the ROC to establish a more inclusive religious coalition for the official dialogue it spearheads with UNESCO, the Russian government elected simply endorses the exclusive relationship as a legitimate representation of Russia's religious mosaic. ${ }^{338}$

This policy of exclusion, discrimination, and intolerance is advanced further under the banner of so-called "traditional values," and impacts not only religious minorities but the treatment of Russia's lesbian, gay, bisexual, and transgender communities as well. In a Siberian court, prosecutors argued Scientology's key texts undermined Russia's "traditional spiritual values." As noted above, the court agreed, deciding to ban such works as extremist. ${ }^{339}$ To be certain, the ROC's vision of traditional values being advocated on the international level excludes any recognition of rights for these individuals and groups. And this type of opposition is made evident domestically in the prohibition of gay pride parades and the reported demolition an Orthodox church where a priest officiated a gay marriage. 340 Patriarch Kirill recently appears-at least when meeting with international interlocutors-to have moderated his stance vis-a-vis homosexuality, claiming the ROC opposes persecution of "these people." However, in the same breath, he continues to denounce gay parades as a "blatant display of sodomy" that "degenerates public morality." 341 More recently still, the ROC "welcome[d]

338 See Lavrov, supra note 172 (describing the MOFA and the ROC's plan to work jointly to establish a Consultative Council of Religions via the United Nations).

339 See generally Alexander Bratersky, Extremism Cases Call Experts Into Question, MOscow TIMES, Apr. 23, 2010, available at DOW JONES Document MOSTIM0020100422e64n00002 (highlighting recent instances of intolerance of nontraditional religious movements in Russia).

340 See Russian Chapel Razed after Gay 'Marriage,' WASH. TIMES, Oct. 8, 2003, http://www.washingtontimes.com/news/2003/oct/8/20031008-113616-3077r/ (stating that the church was deemed defiled and the officiating priest, Father Vladimir Enert, was defrocked).

341 Ann-Dorit Boy, Gay Activists Risk Violence to Hold Parade, DER SPIEGEL (May 12, 2009), http:/ / www.spiegel.de/international/world/0,1518,624286,00.html. In December 2009, Kirill claimed before the Secretary General of the Council of Europe, "We respect the person's free choice, including in sex relations." Russian Church leader condemns discrimination of homosexuals, RIA NOVOSTI (Dec. 23, 2009), 
solidarity between the government and society in rejecting sex minorities' attempts to hold a gay pride parade in Moscow." 342 According to Vladimir Legoyda, the head of the Moscow Patriarchate's Information Department, the gay pride parade symbolizes one of many "actions challenging traditional values ... and the values of traditional religions, which view people's deeds in the categories of sin and virtue. ... 'This is just another attempt to erode the clear borderlines between the good and the evil.'" 343

Russia's efforts to promote an international norm prohibiting defamation of religion lend legitimacy to the government's parallel willingness to prosecute related offenses under the guise of incitement in domestic courts. The ROC continues to be a steadfast proponent of such laws as well as the organization that primarily benefits from its enforcement. For example, government prosecutors sought jail time against Yuri Samodurov, the former director of Moscow's Andrei Sakharov "Peace, Progress, and Human Rights" Center, and Andrei Yerofeev, an art historian, for "incitement of hatred or enmity, as well as abatement of dignity of a person or group of persons . . . "344 The criminal charges

http://en.rian.ru/russia/20091223/157334493.html. Six months later, Kirill voiced "serious concern" over the challenges facing ecumenical dialogue with some Protestant churches because of their "new positions" on moral issues including homosexuality. Brian Hutt, Russian Orthodox Head Concerned With ProGay Protestant Churches, THE CHRISTIAN Post, Jun. 29, 2010, http:/ / www.christianpost.com/news/russian-orthodox-church-raises-concernsover-pro-gay-protestant-churches-45724/.

342 Russian Church Supports Ban on Gay Pride Parade, Interfax (May 31, 2010), http:/ / www.interfax-religion.com/ ?act=news\&div=7315.

$343 \mathrm{Id}$. Tied to the dispute over the gay pride parades, the Moscow City Court rejected a petition filed against mayor Yuri Luzhkov demanding he apologize for allegedly offensive statements made on television explaining why Moscow would ban the parade. Mayor Luzhkov was quoted as saying, "Our morally healthy society does not accept all these faggots." Moscow City Court Upholds Court Ruling Against Gay Pride Parade Organizers, INTERFAx (July 2, 2010), http:/ / www.interfaxreligion.com/?act=news\&div $=7436$. Until President Medvedev deposed him in 2010 for unrelated reasons, Luzhkov was a longstanding supporter of the Moscow Patriarchate. See Blitt, One New President, supra note 2, at 1345; see also Blitt, How to Entrench a De Facto State Church in Russia, supra note 2, at 725.

344 See Ugolovnyi KodeKs Rossiskoi Federatsi [THE CRIMINAL CODE OF THE RUSSIAN FEDERATION] [UK RF] [Criminal Code] art. 282 (Russ.), available at http://www.legislationline.org/download/action/download/id/1697/file/0cc1 acff8241216090943e97d5b4.htm/preview. The crime makes no allowance for a positive defense on the basis of academic or artistic freedom. 
followed the launch of an exhibition entitled "Forbidden Art," 345 which allegedly "debas[ed] the religious beliefs of citizens and incit[ed] religious hatred." 346 Although supporters of Samodurov and Yerofeev petitioned the U.N. High Commissioner for Human Rights to intervene in the case on the defendants' behalf,'347 Judge Svetlana Alexandrovna branded the artwork, "a public offense to Christians" 348 and found the pair guilty of committing actions aimed at inciting hatred, sentencing each to pay fines totaling approximately $\$ 12,000 .{ }^{349}$

The "Forbidden Art" trial, "allegedly instigated by elements within the Moscow Patriarchate," 350 follows on the heels of a

345 The exhibit represented a collection of previously banned artwork.

346 See A.O. \& E.L, What Happens When You Display "Forbidden Art," THE ECONOMIST, June 24, 2010, http://www.economist.com/blogs/easternapproaches/2010/06/blasphemy_mo scow (describing how prosecutors in Russia are demanding a three year jail sentence for those responsible for putting "forbidden art" on display at a museum); see also Russian Prosecutors Seek Jail Terms For 'Forbidden Art' Organizers, RFE/RL (June 22, 2010), http://www.rferl.org/content/Russian_Prosecutors _Seek_Jail_Terms_For_Forbidden_Art_Organizers_/2079532.html (stating that the exhibited works were not authorized for exhibition in Russia and that many of them combined Soviet and Religious iconography in provocative ways).

347 See Rights Campaigners Turn to UN Over Trial of Blasphemous Exhibit Organizers, INTERFAX (Jul. 1, 2010), http://www.interfax-religion.com $/$ ?act=news\&div=7430 (discussing action taken by Russian human rights activists following the prosecution of organizers of a controversial art exhibit in Moscow).

348 See Forbidden Art-2006 Exhibition Organizers to Pay Fine, RIA Novosti (Jul. 12, 2010), http://en.rian.ru/russia/20100712/159769504.html (describing the ruling against exhibition organizers and the penalties a Moscow court imposed on them for the controversial exhibit).

349 See Joanna Impey, Russians Convicted Over Forbidden Art Show, DeUTSCHE WeLLE, Jul. 12, 2010, http://www.dw-world.de/dw/article/0,5784213,00.html (describing the conviction of the art exhibit organizers and the Russian Orthodox Church's condemnation of the exhibit); see also Richard Boudreaux, 'Forbidden Art' Draws a Fine, WALL. ST. J., Jul. 13, 2010, http://online.wsj.com/article /SB10001424052748704288204575362651473284486.html (describing the punishment given to the Russian art exhibit organizers and how the outcome has generated criticism from both the Russian religious right and from Russian rights activists); Russians Convicted and Fined over Forbidden Art Show, BBC News, Jul. 12, 2010, http://www.bbc.co.uk/news/10595903 (focusing on the implications of the court's punishment of the exhibit curators). Amnesty International labeled the verdict, "yet another blow to freedom of expression in Russia." See Laetitia Peron, Russia Convicts Art Experts Over Exhibition, AFP ENGLISH WIRE, Jul. 12, 2010, available at WL 7/12/10 AGFRP 14:41:48.

350 U.S. COMM'N ON INT'L RELIGIOUS FREEDOM, supra note 26, at 282. 
similar lawsuit, also targeting Samodurov, for a 2003 exhibit entitled "Caution, Religion!" that featured contemporary Russian artists addressing the issue of rising clericalism. ${ }^{351}$ In that incident, after an "organised group of self-professed Orthodox believers" 352 ransacked the exhibit,",53 the state opted to prosecute Samodurov and Lyudmila Vasilovskaya, the exhibit's curator, for "inciting hatred and enmity," again under article 282(2) of Russia's Criminal Code. 354 The investigator in charge of serious crimes for Moscow's Tsentralniy district police office alleged that Samodurov and Vasilovskaya conspired to:

Stage an exhibition in Moscow which was clearly aimed at conveying publicly, in a graphic and demonstrable manner, humiliating and offensive views towards the Christian religion in general and Orthodox Christianity and the Russian Orthodox Church in particular . . . which incited hatred and enmity and were degrading to the dignity of individuals who belonged to the Christian religion in

351 The European Court of Human Rights admissibility decision provides additional details regarding the actual content of the exhibit. See Samodurov v. Russia, App. No. 3007/06, Eur. Ct. H.R. (Dec. 15, 2009), available at http://www.article19.org/data/files/pdfs/analysis/russia-first-decision-yuriysamodurov.pdf (holding that the facts of the case, and the complaint made, are inadmissible before the European Court of Human Rights).

352 See id. at 3 (stating that the group "broke into the exhibition hall and destroyed a significant number of exhibits by tearing hem down or daubing then with a spray paint from cans they had brought with them").

353 A district court deemed that this did not amount to a criminal offense. Id. at 5 .

354 This decision came despite an initial investigation that concluded there was insufficient evidence to show the artists' requisite intent to publicly display their work. Id. Article 282 of Russia's Criminal Code provides that,

[a]ctions aimed at the incitement of hatred or enmity, as well as abasement of dignity of a person or a group of persons on the basis of sex, race, nationality, language, origin, attitude to religion, as well as affiliation to any social group, if these acts have been committed in public or with the use of mass media

shall be punishable inter alia by either a fine, compulsory works, corrective works or by "deprivation of liberty" for a term ranging up to five years. UGOLOVNYI KODEKS ROSSIISKOI FEDERATSI [THE CRIMINAL CODE OF THE RUSSIAN FEDERATION] [UK RF] [Criminal Code] art. 282 (Russ.). 
general and Orthodox Christianity ... . and the Russian Orthodox Church in particular . . . .355

At trial, the prosecution led testimony from six expert witnesses. Of the six, none had a background in contemporary art. Among their conclusions were that the exhibit's purpose was "to discredit Christianity" through "explicitly insulting and blasphemous" 356 works of art. In a bizarre twist, the District Court rejected the defense's expert witnesses on the basis that the defendant's actions "undermined the human dignity of believers." 357 Consequently, in the Court's view, allowing the expert testimony would be unconstitutional insofar as it violated the "rights and freedoms of others" and constituted "[p]ropaganda or agitation instigating social, racial, national or religious hatred and strife." 358 With this imaginative spinning of Russian constitutional law, the court rejected out of hand the ability to raise any meaningful defense, essentially holding that any expert ready to testify on behalf of the defendants was a priori in breach of the Constitution. The court convicted the defendants and fined each in the amount of $\$ 4,000$. On appeal, the Moscow City Court "upheld the judgment in its entirety, reiterating parts of the wording." 359 As of this writing, a final decision on the admissibility of this case is pending before the European Court of Human Rights (ECHR). Samodurov and Yerofeyev have also expressed their intent to pursue an ECHR appeal against the July 2010 verdict filed against them.

\section{CONCLUSION}

This article calls attention to the growing religionization of Russia's foreign policy and its ensuing implications for constitutional fidelity and respect for human rights both at home and abroad. The Medvedev-Putin government has developed a seemingly open-ended concept of "spirituality" in the context of its national security policy that, on closer examination, translates into

355 Samodurov, App. No. 3007/06, Eur. Ct. H.R, at 6.

356 Id. at 7-8.

357 Id. at 10.

358 Samodurov, App. No. 3007/06, Eur. Ct. H.R, at 10 (citing articles 17(3) and 29(2) of the Russian Constitution).

359 Samodurov, App. No. 3007/06, Eur. Ct. H.R, at 11. 
exclusive espousal of Russian Orthodox values. Beyond the rhetorical endorsement of Orthodoxy as glue for Russian nationalism, the government has taken practical steps to incorporate the Moscow Patriarchate's views and infrastructure in the formulation and promulgation of its foreign policy. ${ }^{360}$ Here, Foreign Minister Lavrov's observations are instructive:

The tradition of cooperation between national diplomacy and the Russian Orthodox Church stretches back into centuries. We are still working hand in hand, helping the Russian diaspora and protecting the rights of Russians who have found themselves far away from the Homeland. The Church, in fact, solves the same problems as diplomacy.... Last year's pastoral trip of His Holiness Patriarch Kirill to Ukraine, the visits to Belarus, Kazakhstan, Armenia and Azerbaijan, and the recent CIS Interreligious Council meeting in Baku have helped strengthen ties between peoples and established the prerequisites for building up interstate relations. 361

When viewed in the context of Russia's ongoing internal dismantling of church-state separation, the existence of a parallel ROC-State partnership on the international level should come as no surprise. What is surprising, however, is the extent of this partnership and the multiple channels through which it is being articulated. This level of enhanced cooperation and partnership comes at the expense of undermining respect for Russia's constitutional order, which is premised on the fundamentals of secularism, separation of church and state, and equal nondiscriminatory treatment for all religious groups. By formulating and executing elements of Russia's foreign policy in lockstep with the Church, Medvedev has effectively abrogated his loyalty oath to "respect and protect human and civil rights and

360 This is in line with Medvedev's National Security Strategy, which calls on Russia to use "political, legal, foreign, military, and other instruments for the protection of state sovereignty and national interests." See National Security Strategy of the Russian Federation until 2020, supra note 16, at pt. II(19) (emphasis added).

361 Transcript of Speech by Minister of Foreign Affairs Sergei Lavrov at the XIV World Russian People's Council, supra note 128. Kirill's trips to Ukraine and Armenia are discussed infra Part 3.2.5.3. 
freedoms, [and] observe and protect the Constitution." 362 No less egregious, Medvedev has flaunted principles of his own design intended to safeguard the national interest insofar as the National Security Strategy calls for ensuring the "inviolability of the constitutional order," as well as protecting the constitutional order and "fundamental rights and freedoms of individuals." 363 However, Medvedev is not alone in his contempt for the constitution. The government-as well as the ROC-has willingly placed itself above the law by subordinating the clear social compact agreed upon by the Russian people and enshrined in the constitutional text. Confronted with this overwhelming evidence of a total disconnect from constitutional fundamentals, Prime Minister Putin's straight-faced assertion in the context of a nowconfirmed 2012 presidential run that "Neither I nor President Medvedev will do anything which contradicts current Russian legislation or the country's fundamental law - the constitution,"364 hardly merits comment.

The ROC, for its part, has been quick to embrace the government's invitation into the realm of foreign policy planning as a means of boosting its international status and influence, as well as further entrenching its domestic agenda. In exchange for this privilege, the Moscow Patriarchate has willingly opened up its churches and missions abroad as an ostensibly neutral yet consistent proponent of the government's interests. Disturbingly, this relationship carries the toxic risk of compromising the Church's post-Soviet independence and bringing about a return of the subordination of the Russian Orthodox faith to the Kremlin's political diktats. 365

362 KONSTItUtsila ROSSIISKOI FEDERAtSII [KONST. RF] [RUSSIAN CONSTITUTION] art. 82(1) (Russ.)

363 National Security Strategy of the Russian Federation until 2020, supra note 16, at Parts III(21) and IV(2)(35), respectively.

364 See Andreas Rinke, Russia's Putin Hints at Kremlin Return in 2012, REUTERS (Sept. 6, 2010), http://www.reuters.com/article/2010/09/06/us-russia-putinidUSTRE68528W20100906 (discussing statements made by Russian Prime minister Putin hinting at the possibility that he will run for President again in 2012).

365 Consider former KGB overseas counterintelligence director Oleg Kalugin's observation that "Russia's current [political] system is based on the KGB at the head of the government, on the Russian Orthodox Church as a former part of KGB agencies among the clergy, and on Russian business[,]" and that "the 
To be certain, the unfolding relationship described above has fomented a counter-intuitive situation, whereby a constitutionally declared secular state promotes a particular religious agenda as part of its foreign policy on the global stage. The consequences of this partnership have serious implications at the international level, manifested in efforts to supplant universal human rights norms and legitimate the rationale that certain select "traditional" or "major" religions merit greater influence in the formulation of international rules than others. These international policies, in turn, reverberate within Russia's domestic realm so as to exacerbate already harmful government actions. For example, international endorsement of the belief that certain faiths should be privileged at the expense of others reinforces existing discriminatory treatment of so-called "nontraditional" religions in Russia. Likewise, support for a global ban on defamation of religion further justifies the prosecution of individuals like Samodurov and groups such as the Jehovah Witnesses under incitement and extremism laws that purport to comply with international human rights norms. In other words, Russia's neglect of explicit constitutional directives in the foreign policy context compounds the already negative treatment afforded to domestic human rights protections intended to safeguard, inter alia, freedom of expression and freedom of religion or belief.

The ongoing suppression of Russian civil society will likely further embolden Russian government and ROC officials to graft Orthodox "spiritual" values onto additional policy initiatives abroad. The success of such efforts will in part be contingent upon Russia's ability to maintain and foster international alliances with like-minded, relativist-inclined regimes and religious groups. The other contingency in this equation rests with the position taken by those committed to upholding international human rights and constitutional law. Until now, Russia's policies on the international stage have been met with relative silence from other states and intergovernmental bodies such as the Council of Europe

Russian Orthodox Church always played a significant role in [the KGB's recruitment efforts], and it is likely to play an even greater role today." Former KGB General Kalugin Calls U.S.-Russia Spy Saga 'A Farce', RFE/RL, Jul. 17, 2010, http://www.rferl.org/content/Former_KGB_General_Kalugin_Calls_US_Russia _Spy_Saga_A_Farce/2102400.html. 
and OSCE. However, given the dire situation within Russia and the potential deleterious impact of its foreign policy, it behooves these actors to rally in defense of Russia's beleaguered citizens and their discounted democratic will. Such a step will require more vigorously resisting Russia's attempts to undermine the content and integrity of universal human rights law and a redoubling of efforts to scrutinize and influence change on the domestic front. The overriding policy question here should be: what are the implications of a given action on the content and inviolability of universal human rights and the consequences for civil society in Russia today?

Admittedly, this clarion call may run afoul of the Kremlin's stated desire to retrench an anachronistic understanding of state sovereignty and promote select "spiritual" values at home and abroad. However, given the associated risks for the stability of universal human rights, Moscow's deleterious policies should no longer go unchallenged. In staking out a tougher and more deliberate position against these policies, states, intergovernmental bodies, and NGOs alike should take comfort in the fact that the Kremlin and Moscow Patriarchate's agenda is by no means necessarily supported by a majority of Russians. Beyond the clear disagreement over prioritizing threats to Russia's national security,366 domestic evidence points to a backlash against the Church's preferential treatment, ${ }^{367}$ even in the face of a pervasive inability to effectively express dissenting views through traditional political, media, and civil society channels.

366 See Opinion poll: Only 3\% of Russians Think the Lack of Spiritual Values to be a Major National Threat, supra note 51.

367 For example, there has been a backlash against ROC plans to construct between 100 and 200 new churches in the Moscow area. See Paul Goble, Muscovites Protest Against Construction Of New Orthodox Churches, WINDOW ON EURASIA (Nov. 28, 2010), http://windowoneurasia.blogspot.com/2010/11 /window-on-eurasia-muscovites-protest.html (describing recent protests by Muscovites against a plan to construct 100 to 200 new Russian Orthodox churches in the Moscow area); see also Moskvichi vyistupili protiv stroitel stva pravoslavnyh tserkvei [Muscovites opposed the construction of Orthodox Churches], ANSAR, Nov. 27, 2010, http://www.ansar.ru/society/2010/11/27/8751 (describing the protests against the construction project). 